8 Corresponding author (email: chewd@tcd.ie)

9 Number of words of manuscript text: 19,227

\section{Number of words of references: 9,265}

Number of words in figure captions (16 figures): 712

No tables.

\section{Abstract}

\title{
The Laurentian Caledonides of Scotland and Ireland
}

DAVID M. CHEW 1 \& ROB A. STRACHAN ${ }^{2}$

\author{
${ }^{1}$ Department of Geology, School of Natural Sciences, Trinity College Dublin, Dublin 2, \\ Ireland \\ ${ }^{2}$ School of Earth and Environmental Sciences, University of Portsmouth, Portsmouth, \\ P01 3QL, UK
}

Running title: The Caledonides of Scotland and Ireland (39 characters)

The Caledonides of Britain and Ireland are one of the most intensively studied orogenic belts in the world. This review considers all the tectonic events associated with the development and closure of the Iapetus Ocean. It first summarizes the tectonic evolution of each segment involved in the Scottish-Irish sector of the Caledonides and then reviews the temporal evolution of the Caledonian orogeny. Three main tectonic phases are recognized in the Scottish-Irish Caledonides: an Early to Middle Ordovician (475 - $465 \mathrm{Ma}$ ) phase termed the Grampian Orogeny, a phase of Silurian (435-425 Ma) tectonism restricted to the Northern Highland Terrane of Scotland termed the Scandian Orogeny, and an Early Devonian (395 Ma) phase, termed the Acadian Orogeny. The Grampian Orogeny was caused by the collision of the Laurentian continental margin with an oceanic arc terrane and associated supra-subduction zone ophiolites during the latest Cambrian to Early Ordovician. Following the Grampian arc-continent collision event there was a subduction polarity reversal. This facilitated continued subduction of Iapetan oceanic lithosphere and an Andean-type continental margin developed on and adjacent to the Laurentian margin in the Middle Ordovician along with a substantial thickness of accretionary prism sediments (the Southern Uplands - Longford-Down terrane). The Iapetus Ocean is believed to have disappeared by the Late Silurian based 
33 on the faunal record and a continent - continent collision ensued. The absence of 34 significant regional deformation and metamorphism associated with the Late Silurian 35 collision between Avalonia and the Scottish-Irish margin of Laurentia suggests that the 36 continental collision in this sector of the Caledonian-Appalachian orogen was 'soft' or 37 highly oblique. The exception is the Northern Highlands Terrane of Scotland that was 38 believed to have been situated $500-700 \mathrm{~km}$ to the north along orogenic strike. This 39 terrane records evidence for significant Silurian regional deformation and 40 metamorphism attributed to the collision of the Laurentian margin of East Greenland 41 with Baltica (the Scandian Orogeny). Current controversies in the Laurentian 42 Caledonides of Scotland and Ireland are discussed at the end of this review.

\section{Introduction}

45 The Caledonides of Britain and Ireland occupy a key position between the Appalachian 46 orogen of eastern North America and the Caledonides of Scandinavia and East 47 Greenland. They are one of the most intensively studied orogenic belts in the world, and 48 have served as a superb natural laboratory for the development of many key geological 49 concepts, including thrust tectonics (e.g. Peach et al., 1907), regional metamorphism 50 (e.g. Barrow, 1893) and the origin and emplacement of granitic magmas (e.g. Read, 51 1957).

52 In this review we focus mainly on the Early Ordovician - Early Silurian evolution of the 53 Laurentian Caledonides of Scotland and Ireland. The term 'Caledonian orogenic cycle' is 54 employed here to include all the Cambrian, Ordovician, Silurian and Devonian tectonic 55 events associated with the development and closure of the Iapetus Ocean, similar to the 56 definition of McKerrow et al. (2000). These tectonic events are illustrated in Figure 1 57 and occurred between Laurentia (to the northwest) and Baltica and Avalonia (to the 58 southeast and east). They encompass the evolution from the Laurentian passive margin 59 to a series of arc-arc, arc-continent and continent-continent collisions related to the 60 closure of the Iapetus Ocean. In Scotland and Ireland, the Caledonian orogenic cycle on 61 the Laurentian margin comprises three main phases: an Early - Middle Ordovician (475 62 - $465 \mathrm{Ma}$ ) phase termed the Grampian Orogeny, a phase of Silurian (435-425 Ma) 63 tectonism restricted to the Northern Highland Terrane of Scotland termed the Scandian 64 Orogeny, and an Early Devonian (405 Ma) phase, termed the Acadian Orogeny.

65 The Grampian Orogeny was primarily caused by the collision of the Laurentian 66 continental margin of Scotland and NW Ireland with an oceanic arc terrane during the 67 latest Cambrian to Early Ordovician (Fig. 1). This arc was intra-oceanic, and was 68 produced by the subduction of oceanic crust within the Iapetus Ocean. Following this 69 arc-continent collision event and the associated obduction of supra-subduction zone 
70 ophiolites onto the Laurentian margin (Dewey \& Shackleton, 1984), there was a

71 subduction polarity reversal. This facilitated continued subduction of Iapetan oceanic

72 lithosphere and an Andean-type continental margin developed on the Laurentian

73 margin in the Middle Ordovician along with a substantial thickness of accretionary

74 prism sediments (the Southern Uplands - Longford-Down terrane, Fig. 2).

75 During the Late Ordovician, Baltica and the Avalonian microcontinent progressively 76 approached both each other (closing the Tornquist Sea) and the Laurentian margin 77 (closing the Iapetus Ocean). The faunal record suggests that the Tornquist Sea closed in 78 the Late Ordovician as faunas from Avalonia began to mix with Baltic faunas in the 79 Caradoc, while by the Ashgill, British and Scandinavian faunas were similar at species 80 level (Cocks et al., 1997). The Iapetus Ocean is believed to have disappeared by the Late 81 Silurian based on the faunal record (e.g. Cocks and Fortey, 1982), and a continent 82 micro-continent collision ensued. The Northern Highlands Terrane of Scotland (Fig. 2) 83 records evidence for significant Silurian regional deformation and metamorphism that 84 is attributed to the collision of the Laurentian margin of East Greenland with Baltica 85 (the Scandian Orogeny). It is thought that the Northern Highlands terrane was situated $86500-700 \mathrm{~km}$ to the north along orogenic strike for it to have it participated in the 87 Scandian Orogeny as many of the terranes generally inferred to have been positioned to 88 the south (e.g. the Midland Valley Terrane, Fig. 2) show no evidence for this Silurian 89 tectonic event.

90 The absence of significant regional deformation and metamorphism associated with the 91 Late Silurian collision between Avalonia and the Scottish-Irish margin of Laurentia 92 suggests that the continental collision in this sector of the Caledonian-Appalachian 93 orogen was 'soft' or highly oblique. It is generally believed that Late Silurian / Early 94 Devonian sinistral strike-slip movements of up to several hundred kilometres occurred 95 along the Great Glen and Highland Boundary and Southern Upland faults (Fig. 2; Soper 96 et al. 1992; Dewey \& Strachan 2003; Cawood et al. 2012, see, however, Tanner 2008). 97 The final stage of the Caledonian orogenic cycle in Scotland and Ireland is marked by 98 post-orogenic clastic rocks of Middle Devonian age (or younger) resting unconformably 99 on folded cleaved rocks that range in age from Cambrian to Early Devonian. On the 100 Avalonian side of the Iapetus Suture this event is termed the Acadian Orogeny after 101 Acadia, the francophone region of maritime Canada where it was originally defined. In 102 contrast, Early Devonian deformation north of the Iapetus Suture has been ascribed to 103 post-collisional sinistral transtension between Laurentia and Avalonia-Baltica (Dewey 104 \& Strachan 2003).

105 The late stages of the Caledonian orogenic cycle in Scotland and Ireland were also 106 marked by the intrusion of large volumes of granitic magma with a predominantly calc107 alkaline "I" type character. While their chemistry is clearly compatible with a 
subduction-related origin, much of the magmatism (which spans a time period from 430 - $380 \mathrm{Ma}$ ) post-dates the final closure of the Iapetus Ocean. Their genesis has been attributed by Atherton and Ghani (2002) to post-collisional slab break off.

In this review of the Laurentian Caledonides of Scotland and Ireland, we first discuss the various tectonic elements / terranes involved in the Caledonian orogeny. A summary of the temporal evolution of the Caledonian orogenic belt is then provided. The temporal evolution focusses mainly on the Grampian and Scandian orogenies and does not consider in detail late Caledonian magmatism or strike-slip faulting. Current controversies in the Laurentian Caledonides of Scotland and Ireland are then discussed at the end of this review.

\section{Tectonic elements of the Scottish and Irish Caledonides}

The various tectonic elements involved in the Caledonian orogeny in Scotland and Ireland are now discussed in turn from northwest to southeast. These tectonic elements are illustrated on Figure 2 and Figure 3 and include:

i) The Laurentian foreland (Hebridean terrane) which comprises Lewisian basement and its undeformed sedimentary cover.

ii) The Northern Highlands terrane which consists of the deformed Laurentian cover sequence of the Moine Supergroup and its probable basement represented by the "Lewisianoid" inliers of the NW Highlands.

iii) The Grampian terrane which includes the deformed Laurentian cover sequence of the Dalradian Supergroup and its basement represented by the Annagh Gneiss Complex in NW Ireland and the Rhinns Complex in SW Scotland. This terrane also locally contains Grampian syn-orogenic arc intrusives. Early Ordovician accretionary complexes (the Highland Border Complex in Scotland and the Clew Bay Complex in western Ireland) and probable para-autochthonous Laurentian crustal fragments such as the Slishwood Division crop out on the southeastern margin of the Grampian terrane (Fig. 2).

iv) The Midland Valley terrane consists of Late Cambrian - Early Ordovician suprasubduction ophiolite complexes such as Shetland to the north of mainland Scotland, Ballantrae in SW Scotland, Tyrone in NW Ireland and Clew Bay in western Ireland. It also contains fragments of the Grampian volcanic arc and its associated fore-arc basin, such as the Lough Nafooey arc and South Mayo Trough in western Ireland. Detached Laurentian crustal fragments such as the Tyrone Inlier and the Dalradian Supergroup rocks of Connemara also crop out within this composite terrane (Fig. 2). Silurian fore- 
arc and inter-arc successor basins were deposited on the eroded remnants of the Grampian arc and associated ophiolites.

v) The Southern Uplands - Longford-Down terrane represents a successor subduction zone system following the Grampian orogeny and comprises a thick sequence of Mid-Ordovician to Early Silurian accretionary prism rocks.

\section{The Laurentian foreland}

The Hebridean terrane of NW Scotland represents the external zone of the Laurentian Caledonides. It consists of lower-crustal, high-grade gneisses of the Archaean to Palaeoproterozoic Lewisian Gneiss Complex (Park et al. 2002; Kinny et al. 2005) that are overlain unconformably by two Precambrian sedimentary successions. The oldest of these is the c. 1200 Ma Stoer Group, a $2 \mathrm{~km}$ thick sequence of continental sandstones and siltstones that was deposited in a localized NNE-trending rift (Stewart 2002 and references therein). The Sleat Group of Skye may have been deposited at approximately the same time. Both sequences contain detrital zircons of Archaean to Palaeoproterozoic age that were probably derived from the nearby Lewisian Gneiss Complex, the upper part of the Sleat Group also containing some Mesoproterozoic grains for which there is no obvious exposed source in NW Scotland (Rainbird et al. 2001; Kinnaird et al. 2007).

The Stoer Group was tilted and eroded before deposition of the unconformably overlying Torridon Group. This is a $5 \mathrm{~km}$ thick sequence of arkosic fluviatile sandstones, derived mainly from the west (Park et al. 2002; Stewart 2002 and references therein). Detrital zircons range in age from 3.1 - 1.05 Ga with sub-populations at 1.8, 1.65 and 1.1 Ga (Rainbird et al. 2001). A maximum age for sedimentation is provided by a detrital zircon age of $1060 \pm 18 \mathrm{Ma}$ (Rainbird et al. 2001). Rb-Sr whole-rock regression ages of $994 \pm 48 \mathrm{Ma}$ and $977 \pm 39$ Ma obtained from siltstones are thought to correspond to the time of early diagenesis (Turnbull et al. 1996). The Torridon Group was therefore probably deposited during the final stages of the Grenville Orogeny (Rainbird et al. 2001). There are no exposed sources in the Hebridean terrane for the 1.1 Ga detrital zircons. Accordingly, the current consensus is that the Torridon Group was deposited in a foreland basin to the Grenville mountain belt, with some detritus derived from distal sources such as NE Canada (Krabbendam et al. 2008, see however Williams \& Foden 2011).

The Lewisian Gneiss Complex and the Torridon Group are in turn overlain unconformably by Early Cambrian to Middle Ordovician shallow marine platform sediments that total c. $1 \mathrm{~km}$ in thickness (McKie 1990; Park et al. 2002). These extend from the north Scottish coast to the Isle of Skye (Fig. 4), with almost identical 
182 correlative sequences extending along the length of the Caledonide-Appalachian orogen

183 between NE Greenland and eastern North America. These sequences are all broadly

184 transgressive and characterized by clastic sedimentary rocks in their lower parts (the

185 Ardvreck Group), passing upwards into carbonates (the Durness Group). The Late

186 Arenig to Early Llanvirn age of the youngest carbonate unit in NW Scotland provides a

187 maximum age for Caledonian orogenic activity sensu lato.

\section{The Northern Highlands terrane}

189 The Northern Highlands terrane is comprised mainly of the deformed Laurentian cover 190 sequence of the Moine Supergroup along with local basement inliers of gneissic rocks 191 which bear close similarities to the Lewisian Gneiss Complex. The Northern Highlands

192 terrane is separated from the Laurentian foreland by the Scandian Moine Thrust, and 193 from the Grampian terrane by the Great Glen Fault (Fig. 2).

194 Laurentian basement in the Northern Highlands terrane - the "Lewisianoid" inliers

195 The Moine Supergroup is structurally interleaved with infolds and tectonic slices of 196 orthogneissic basement that has long been correlated on lithological grounds with the 197 Archaean-Palaeoproterozoic Lewisian Gneiss Complex of the Caledonian foreland (Fig 198 2; Flett 1905; Peach et al. 1907; Read 1931; Tanner et al. 1970; Rathbone \& Harris 199 1979). U-Pb SIMS zircon dating indicates Neoarchaean protolith ages in the range 2.9$200 \quad 2.7$ Ga for basement gneisses in north Sutherland and Glenelg (Fig. 2), thus confirming 201 the broad similarity in age with the foreland basement (Friend et al. 2008). Most inliers 202 are dominated by tonalitic to dioritic, hornblende gneisses, with subordinate 203 hornblendite, serpentinite and garnet-pyroxene lithologies. Metasedimentary units of 204 marble and pelite occur in some inliers. The inliers consistently lie at the lowest 205 structural levels in successions when the effects of thrusting and/or folding are 206 removed. Contacts between the basement gneisses and the adjacent Moine rocks are 207 often concordant as a result of high levels of ductile strain. However, where 208 sedimentary structures are preserved the Moine rocks consistently face away from 209 those basement inliers that occupy fold cores. In some cases, Moine basal 210 conglomerates are in contact with basement gneisses and cross-bedding is preserved 211 within a few metres of their mutual contacts (Ramsay 1958; Strachan \& Holdsworth 212 1988; Holdsworth 1989). Accordingly, the consensus is that the inliers represent 213 fragments of the basement upon which the Moine Supergroup sediments were 214 deposited.

215 The Proterozoic history of many of the basement inliers is generally poorly constrained.

216 The U-Pb SIMS analyses of zircons from basement inliers presented by Friend et al. 217 (2008) yielded complex discordant patterns, probably the result of a Palaeoproterozoic 218 metamorphic overprint, although the timing of this event cannot be determined 
219 precisely. However, a more detailed history is available for the eastern Glenelg inlier

220 where Hf data from eclogitic mafic sheets suggest that their igneous protoliths were 221 emplaced at c. $2.0 \mathrm{Ga}$ (Brewer et al. 2003). Furthermore, Sm-Nd whole rock and mineral 222 ages of c. 1050 Ma obtained from these eclogites imply that at least some of the 223 basement inliers were reworked during the Grenville orogeny (Sanders et al., 1984). U$224 \mathrm{~Pb}$ zircon data suggests that upper amphibolite facies retrogression occurred at c. 995 225 Ma (Brewer et al., 2003).

226 The Strathy Complex of east Sutherland (Figs 2, 4) may represent a juvenile addition to 227 the basement to the Moine Supergroup. It is dominated by amphibolites and banded 228 siliceous grey gneisses, the protoliths of which were probably a series of bimodal calc229 alkaline volcanic rocks (Moorhouse 1979; Moorhouse \& Moorhouse 1983; Burns et al. 230 2004). Sm-Nd model ages of c. 1.1-1.0 Ga obtained from the amphibolites suggest a late 231 Mesoproterozoic protolith age (Burns et al. 2004).

232 A Laurentian cover sequence in the Northern Highlands terrane - the Moine Supergroup

233 The Moine Supergroup is a metasedimentary sequence that was deposited along the 234 eastern margin of Laurentia between c.1000 Ma, the age of the youngest detrital 235 zircons, and before c. $870 \mathrm{Ma}$, the age of the oldest intrusive igneous rocks (Friend et al., 236 1997, 2003). It comprises thick, monotonous successions of psammites, semi-pelites 237 and pelites (Holdsworth et al. 1994). Three lithostratigraphical units are recognized 238 (from west to east): the Morar, Glenfinnan and Loch Eil groups (Holdsworth et al., 1994, 239 Fig. 3). The Morar Group was deposited in a range of fluvial to shallow-marine 240 environments (Glendinning 1988; Krabbendam et al. 2008) and may be laterally 241 equivalent with parts of the Torridon Group of the Hebridean terrane (e.g. Kennedy 242 1951; Bonsor et al. 2012). On the mainland, the Morar and Glenfinnan groups are 243 separated by the Sgurr Beag Thrust (Fig. 4; Tanner et al., 1970; Rathbone \& Harris, 244 1979). A possible stratigraphic transition is preserved on the Ross of Mull (Holdsworth 245 et al., 1987), but the terms 'Morar Group' and 'Moine Nappe' can be considered to be 246 effectively equivalent. The Glenfinnan Group is overlain stratigraphically by the Loch Eil 247 Group and these two units comprise the Sgurr Beag Nappe. Both sequences probably 248 accumulated in shallow to deep-water marine environments (Strachan et al. 1988). 249 How these units link north of the Dornoch Firth with the structurally analogous 250 metasedimentary rocks of the Naver and Skinsdale nappes is not well understood 251 (Kocks et al., 2006). Geochronological constraints suggest that the sub-Dalradian 252 Badenoch Group of the Grampian Terrane (Highton et al., 1999, Fig. 3), and the 253 Westings and Yell Sound groups of Shetland (Flinn, 1988; Cutts et al., 2009, Fig. 3) are 254 likely to broadly correlate with the Moine Supergroup. 
255

256

257

258

259

260

261

262

263

264

265

266

267

268

269

270

271

272

273

274

275

276

277

278

279

280

281

282

283

284

285

286

287

288

289

290

291

292

293

The tectonometamorphic evolution of the Moine Supergroup has proved much more difficult to understand than that of the younger Dalradian Supergroup east of the Great Glen Fault. While the latter is dominated by the structural and metamorphic effects of the Grampian orogenic event with little or no further modification, the Moine Supergroup displays a polyorogenic evolution. There is widespread field evidence for polyphase deformation, and complex porphyroblast growth histories imply multiple episodes of low- to upper-amphibolite facies metamorphism (e.g. MacQueen \& Powell, 1977; Zeh \& Millar, 2001). The timing of tectonothermal events is not defined by any intra-orogenic unconformities and is almost entirely dependent on the isotopic dating of metamorphic mineral assemblages and igneous intrusions of known structural age. A range of isotopic ages, some linked to prograde pressure-temperature histories, indicate orogenesis during the mid-Neoproterozoic ('Knoydartian' events at c. 830-725 $\mathrm{Ma}$ ), the early Ordovician (470-460 Ma) and the Silurian (435-425 Ma) (e.g. Vance et al., 1998; Rogers et al., 1998, 2001; Kinny et al., 1999, 2003a; Cutts et al., 2010; Bird et al., 2013).

Early Ordovician (470-460 Ma) deformation and metamorphism that is correlated with the Grampian orogenic event has been demonstrated in the Sgurr Beag and Naver nappes. It may also have affected the Moine nappe, but evidence is at present ambiguous. The eastern parts of the Sgurr Beag and Naver nappes largely escaped later reworking during the Silurian, so Grampian structures in these areas are thought to be preserved in more or less their original orientation. Nonetheless, large-scale structures comparable to those recognized within the Dalradian Supergroup have yet to be identified. The dominant structures are outcrop- to kilometre-scale recumbent tight to isoclinal 'D2' folds. These commonly have curvilinear sheath geometry as a result of heterogeneous, low-angle simple shear parallel to a $\mathrm{N}$-S trending mineral lineation (Holdsworth \& Roberts, 1984). Microstructures and $\mathrm{cm}$-scale shear zones indicate a top-to-the-north sense of shear parallel to the lineation (Strachan, unpublished data). In the eastern Sgurr Beag Nappe, the evidence that these structures are Grampian in age rests on 1) a U-Pb TIMS age of $470 \pm 2 \mathrm{Ma}$ obtained from titanites aligned parallel to the lineation (Rogers et al. 2001), and 2) a U-Pb SIMS zircon age of $463 \pm 4$ Ma obtained from a syn-kinematic pegmatite (Cutts et al., 2010). Additional evidence for Grampian metamorphism in the area derives from 1) a U-Pb LA-ICP-MS monazite age of $464 \pm 3$ Ma (Cutts et al., 2010) and 2) Lu-Hf and Sm-Nd mineral isochrons and garnet-whole rock ages in the range 470-460 Ma obtained from meta-basic intrusions (Bird et al., 2013). Pressure-temperature conditions for metamorphism are $7 \mathrm{kbar}$ and $650^{\circ} \mathrm{C}$ (Cutts, et al. 2010). In the Naver Nappe, syn-D2 migmatites have yielded U-Pb SIMS zircon ages of $467 \pm 10 \mathrm{Ma}$ and $461 \pm 13 \mathrm{Ma}$ (Kinny et al., 1999). Pressure-temperature conditions for the melting are estimated at $11-12$ kbar and $650-700^{\circ} \mathrm{C}$, implying substantial crustal thickening (Friend et al., 2000). 
294 Silurian (435-425 Ma) deformation and metamorphism that is correlated with the

295 Scandian orogenic episode is widespread in the Northern Highlands Terrane of Scotland

296 and is discussed in greater detail in the section on the Silurian collision between Baltica

297 and Laurentia. Regional-scale, NW-directed Scandian ductile thrusting culminated in the

298 development of the Moine Thrust Zone and was accompanied by widespread folding

299 and fabric development under amphibolite- to greenschist-facies conditions (e.g.

300 Strachan \& Holdsworth, 1988; Holdsworth et al., 2007). A prominent mineral lineation

301 is developed throughout the Moine nappe and the lower parts of the Sgurr Beag and

302 Naver nappes, showing a well-defined swing from gently ESE-plunging in the west

303 adjacent to the Moine Thrust to SSE-plunging adjacent to the Naver, Sgurr Beag and

304 Skinsdale thrusts (Fig. 4; Phillips, 1937; Kinny et al., 2003a; Kocks et al., 2006; Law \&

305 Johnson, 2010). Microstructures indicate a general top-to-the-NW sense of shear

306 parallel to this lineation. Subsidiary structures include the Swordly, Torrisdale and Ben

307 Hope thrusts (Moorhouse \& Moorhouse, et al. 1988; Holdsworth et al., 2001). In the

308 vicinity of the ductile thrusts, the composite foliation that contains this lineation

309 intensifies into broad zones of platy, high-strain blastomylonites. Tight to isoclinal folds

310 are developed on all scales, ranging from $\mathrm{NW}$-vergent to reclined, sheath fold

311 geometries (Fig 5; Holdsworth 1989; Alsop et al. 2010, Krabbendam et al. 2011). The

312 key evidence that demonstrates a Silurian age for these structures arises from the

313 isotopic dating of variably-deformed and metamorphosed syn- to late-thrusting

314 granites at different structural levels in the Sutherland nappe pile that have yielded U-

315 Pb zircon and monazite ages of c. 435-425 Ma (Kinny et al., 2003a; Kocks et al., 2006;

316 Alsop et al., 2010).

\section{The Grampian terrane}

318 Much of the Grampian terrane is comprised of Dalradian Supergroup rocks that 319 represent a deformed Laurentian cover sequence. Basement rocks in the Grampian 320 terrane are restricted to the Annagh Gneiss Complex in NW Ireland and the Rhinns 321 Complex in SW Scotland. This section also considers together the para-autochthonous 322 Laurentian crustal fragments of the Slishwood Division and the Tyrone Inlier. It should 323 be noted that the Tyrone Inlier crops out in the Midland Valley terrane and only the 324 metasedimentary rocks are discussed here. The structurally overlying ophiolitic rocks 325 are considered in the section on the Midland Valley terrane.

326 The Grampian terrane is separated from the Northern Highlands terrane by the Great 327 Glen Fault and from the Midland Valley terrane by the Highland Boundary Fault - Fair 328 Head-Clew Bay line. Along this fault zone crops out a series of rocks (the Highland 329 Border Complex in Scotland and the Clew Bay Complex in western Ireland) that are 330 believed to represent an Early Ordovician accretionary complex. 
332 The Annagh Gneiss Complex (AGC) is a Palaeoproterozoic orthogneiss terrane in 333 western Ireland (Figs. 2, 6, 7C) that structurally underlies the Grampian Group 334 Dalradian meta-sedimentary rocks of the northwest Mayo Inlier. The Dalradian rocks 335 adjacent to the Annagh Gneiss Complex basement were deformed and metamorphosed 336 under medium pressure amphibolite-facies conditions during the Grampian Orogeny, 337 with PT estimates for staurolite-kyanite zone metamorphism close to the basement 338 core of $8 \pm 2 \mathrm{kbar}$ and $620 \pm 30^{\circ} \mathrm{C}$ (Yardley et al. 1987). The basement gneisses reached 339 a somewhat higher metamorphic grade with widespread migmatisation in Grenville 340 times (van Breemen et al., 1978).

341 The evolution of the Annagh Gneiss Complex is described in detail in Daly (2009) and 342 Daly (1996). Much of the AGC originated as juvenile Palaeoproterozoic crust 343 represented by the $1753 \pm 3$ Ma calc-alkaline Mullet gneisses (Daly, 1996). These 344 gneisses comprise intermediate to acid orthogneisses whose overall composition is 345 granodioritic to granitic (Winchester and Max, 1984). Early amphibolitised basic bodies 346 are concordant with the main gneissose foliation and may represent dykes or sills. 347 Subsequent intrusive phases include the Late Mesoproterozoic (1271 $\pm 6 \mathrm{Ma}$ ) Cross 348 Point gneisses which have an A-type geochemistry and Palaeoproterozoic $\mathrm{t}_{\mathrm{DM}}$ ages 349 (Daly, 1996). They probably represent anorogenic granitoids formed by melting of the 350 pre-existing Palaeoproterozoic Mullet gneisses with the addition of a mantle-derived 351 mafic component. The Doolough gneisses comprise a small volume of juvenile 352 granitoids and associated basic rocks, which formed at $1177 \pm 4$ Ma (Daly, 1996). 353 Grenville deformation occurred in two stages, between 1177-1015 Ma and from 995354960 Ma (Daly, 1996). These events were separated by the intrusion of the Doolough 355 peralkaline granite at $1015 \pm 4$ Ma and by migmatisation and pegmatite emplacement 356 between 995 and 980 Ma (Daly, 2009). A detailed mineral geochronology study (Daly 357 and Flowerdew, 2005) investigated the possible presence of post-Grenville, pre358 Grampian deformation in the AGC that could be attributed to late Neoproterozoic 359 orogeny. $\mathrm{U}-\mathrm{Pb}$ titanite analyses from the AGC gneisses yield a weighted mean $360{ }^{207} \mathrm{~Pb} /{ }^{206} \mathrm{~Pb}$ age of $963 \pm 8 \mathrm{Ma}$, which dates cooling after the main Grenville 361 metamorphism. The weak discordance of the titanite data suggests that post-Grenville 362 events had little effect on the U-Pb system in titanite.

363 All contacts between the Annagh Gneiss Complex and the Dalradian Supergroup are 364 tectonic. However, the metasedimentary rocks consistently face away from the 365 orthogneisses (Fig. 7C, Max \& Long, 1985) and post-Grenville metadolerites (which are 366 foliated but unmigmatised) cutting the AGC are similar to pre-tectonic dykes in the 367 Dalradian (Daly, 1996). This suggests that the metasediments were stitched together 368 with the older 'basement' prior to deformation. Sm-Nd isotopic data demonstrate that 
the Dalradian metasedimentary rocks were derived from a Palaeoproterozoic source similar to the Annagh Gneiss Complex (Kennedy \& Menuge, 1992). K-feldspar and granitic clasts from pebbly horizons within the basal Dalradian Supergroup strata petrographically resemble lithologies within the AGC and yield U-Pb zircon ages of $\mathrm{c}$.

$3731740 \mathrm{Ma}$ and c. $980 \mathrm{Ma}$, respectively (McAteer et al., 2010a). These ages are within 374 error of the c. 1730-1750 Ma Mullet gneisses and c. 990 Ma Grenvillian migmatitic 375 leucosomes in the underlying AGC. U-Pb detrital zircon data suggest that that the basal 376 Dalradian Supergroup rocks in NW Mayo are correlatives of the Grampian Group of the 377 Dalradian Supergroup in Scotland. These data also imply the NW Mayo Grampian Group 378 Dalradian was deposited after c. $955 \mathrm{Ma}$, with predominant input from c. 1640, c. 1500 379 and c. 990 Ma interpreted Laurentian sources (Labradorian, Pinwarian and Grenvillian 380 terranes, respectively). All of these observations suggest that the Annagh Gneiss 381 Complex represents the depositional basement to the Grampian Group Dalradian of NW 382 Ireland (McAteer et al., 2010a).

\section{Laurentian basement in the Grampian terrane - the Rhinns Complex}

384 The Rhinns Complex occurs within the fault-bounded Colonsay-West Islay block which 385 extends from the Inner Hebrides of Scotland to the island of Inishtrahull off the north 386 coast of Ireland (Fig. 2). The Rhinns Complex is comprised of weakly deformed and 387 metamorphosed alkaline igneous rocks, syenites and gabbros, which have geochemical 388 signatures consistent with formation in a subduction-related magmatic arc. The 389 protolith of the Rhinns Complex gneisses has been dated by the U-Pb zircon method at $3901779 \pm 3$ Ma on Inishtrahull (Daly et al., 1991) and $1782 \pm 5$ Ma on Islay (Marcantonio 391 et al., 1988). In both cases Sm-Nd depleted mantle model ages are only marginally older 392 than the age of the gneissic protolith implying it represents juvenile mantle-derived 393 crust. The largely granodioritic Colonsay orthogneisses (NE Colonsay) are older, 394 yielding a c. 1880 Ma protolith age with c. 1800 Ma cross-cutting pegmatites (Daly et al., 395 2009). Metamorphic zircons from a Rhinns Complex metagabbro at Lossit Bay, Islay 396 yielded U-Pb ages of 1725-1729 Ma (Loewy et al., 2003). This is consistent with a 397 minimum age of $1710 \mathrm{Ma}$ based on ${ }^{40} \mathrm{Ar}-{ }^{-39} \mathrm{Ar}$ hornblende step-heating age from a 398 discordant metagabbro $2 \mathrm{~km}$ northwest of Inishtrahull (Roddick and Max, 1983). To 399 date, no evidence of deformation or metamorphism of Grenville age has been found 400 within the Rhinns Complex.

401 On Colonsay and Islay (Fig. 2), the Rhinns Complex is structurally overlain by c. 5000m 402 of low-grade Neoproterozoic clastic metasedimentary rocks, termed the Colonsay 403 Group (e.g. Bentley, 1988). The Colonsay Group has been correlated with various 404 Neoproterozoic successions in Scotland including the Torridonian, the Moine 405 Supergroup and the Dalradian Supergroup, with most recent interpretations favouring 406 a correlation with the Dalradian Supergroup (Muir et al., 1997; McAteer et al., 2010b). 
407 The contact with the underlying Palaeoproterozoic orthogneisses is generally assumed 408 to represent a tectonically modified unconformity (Bentley, 1988), and rare 409 sedimentary structures suggest that the metasedimentary rocks young away from the 410 orthogneisses (British Geological Survey, 1998). U-Pb detrital zircon ages from the 411 Colonsay Group imply a Laurentian provenance with predominant input from a c. 1780 412 Ma source (Rhinns Complex) and some Grenvillian (c. 1.3-0.95 Ga), Pinwarian (c. 1.51$4131.45 \mathrm{Ga}$ ), Labradorian (c. 1.71-1.62 Ga) and Ketilidian (c. 1.9-1.75 Ga) detritus, while U$414 \mathrm{~Pb}$ (SIMS) analyses of detrital titanite record Grenville metamorphic events in the 415 source terranes (McAteer et al., 2010b). Felsic igneous clasts in the basal Colonsay 416 Group (the Octofad Sandstone) resemble the underlying Rhinns Complex and yield c. 417 1795Ma and ca. $1400 \mathrm{Ma} \mathrm{U}-\mathrm{Pb}$ zircon ages. The data substantiate the interpretation 418 that the Colonsay Group rests unconformably on the Rhinns Complex, and support 419 correlation with the Grampian Group of the Dalradian Supergroup in Scotland (McAteer 420 et al., 2010b).

\section{A Laurentian cover sequence in the Grampian terrane - the Dalradian Supergroup}

422 The Dalradian Supergroup of Scotland and Ireland is a metasedimentary succession that 423 was deposited on the eastern margin of Laurentia during the late Neoproterozoic and 424 Early Cambrian. Existing constraints imply the base is younger than $800 \mathrm{Ma}$ and it 425 extends to at least 510Ma (Smith et al., 1999; Tanner and Sutherland, 2007). It 426 comprises a thick sequence of lithologically diverse metasediments and mafic volcanics, 427 along with three distinct glacigenic units that are correlated with widespread 428 Neoproterozoic glaciations (McCay et al., 2006). Lithostratigraphic correlation is 429 hampered by the almost complete absence of stratigraphically useful fossils, complex 430 polyphase deformation and rapid lateral facies changes. Despite these difficulties, a 431 coherent lithostratigraphy from western Ireland to the Shetland Islands has been 432 established (Harris et al., 1994) comprising four Groups - Grampian, Appin, Argyll and 433 Southern Highland.

434 The structural history of the Scottish Dalradian has been comprehensively studied 435 during the last century. Four main deformational episodes (D1 to D4) have been 436 identified (e.g. Harris et al., 1976), with the structure dominated by a large, recumbent, 437 southeastwards-vergent antiform, the D2 Tay Nappe. The core of the Tay Nappe is 438 exposed solely in the Loch Awe Syncline of the Southwest Highlands (Stephenson \& 439 Gould, 1995). Across this steep belt there is a zone of primary facing divergence, with 440 the structures northwest of the Loch Awe Syncline verging to the northwest and the Tay 441 Nappe verging to the southeast (Fig. 7A). This has been interpreted as a root zone to the 442 major nappe structures (Roberts and Treagus, 1977). In the Central Highlands, the 443 structure is considerably more complex and the evidence for a root zone is equivocal 444 (Rose \& Harris, 2000). Most workers consider the Tay Nappe to have been developed by 
445 southeast-directed D2 shearing of upright D1 structures, with this shearing producing 446 the grossly inverted stratigraphy in the 'Flat Belt' (e.g. Harris et al., 1976; Treagus, 447 1987). Mendum \& Thomas (1997) consider the D1 structures to be initially recumbent 448 and highly modified by northwest-directed D2 shearing. The Tay Nappe been folded 449 downwards adjacent to the Highland Boundary Fault in a monoform termed the 450 Highland Border Downbend. D4 deformation, which caused the downbend (Johnson, 451 1991), resulted in upright folds and an associated strong crenulation cleavage close to 452 the Highland Boundary Fault. A comprehensive account of the structure and 453 lithostratigraphy of the Scottish Dalradian is given in Stephenson et al. (2013) and 454 references therein.

455 In Ireland, the Dalradian outcrop is fragmented into a series of inliers (NW Mayo, 456 Donegal and the Sperrin Mountains, the Central Ox Mountains, Connemara, and NE 457 Antrim; Fig. 2), so deformational and metamorphic events need to be correlated from 458 inlier to inlier. All deformational and metamorphic chronologies for the Irish Dalradian 459 presented here are local; i.e. they correspond to that inlier exclusively and no regional 460 correlation is implied. The two Dalradian inliers in Ireland that offer the longest 461 transects orthogonal to orogenic strike are the NW Mayo and Donegal inliers. The broad 462 structure of the NW Mayo Inlier (Fig. 7C) is similar to that of the Southwest Highlands of 463 Scotland. There are a series of early bedding-parallel shear zones (commonly referred 464 to as "slides" in the literature) that are folded by later (F2) folds. There is a primary 465 facing divergence of the F2 folds either side of a basement core, the Annagh Gneiss 466 Complex. To the north of this 'root zone' shallowly inclined F2 folds face north; to the 467 south, recumbent F2 folds face south (Chew, 2003). Approaching the Achill Beg Fault, 468 the south-facing F2 antiform is rotated into a downward-facing orientation (Fig. 7B) 469 analogous to the Highland Border Downbend. The Dalradian rocks of Donegal (Fig. 7B) 470 show evidence of three phases of Grampian deformation. F1 folds are best seen in north 471 Donegal where there is a primary facing divergence across the Inishowen Syncline, a 472 structure which is similar to the Loch Awe Syncline of Scotland (Hutton and Alsop, 473 1996). D2 in north Donegal is associated with the development of northwest-directed 474 thrust nappes that are separated from each other by D2 slides (Fig. 7B). Within each 475 nappe, recumbent F2 folds face northwest (Hutton and Alsop, 1995). Further south, to 476 the southeast of the Leennan Fault, isoclinal, recumbent F2 folds, such as the Sperrin 477 Nappe, were transported towards the southeast (Alsop, 1996). Major recumbent F3 478 nappes also show a consistent vergence and sense of movement to the southeast (Alsop, 479 1996). During this D3 phase of southeast-directed shearing, the locally inverted 480 Dalradian succession was thrust over elements of the colliding arc terrane along the 481 Omagh Thrust (Fig. 7B; Alsop and Hutton, 1993). 
482 The Dalradian outcrop in Scotland is one of the classic areas for the study of regional 483 metamorphism. Barrow (1893) working in the SE Highlands of Scotland was the first to 484 show that differing mineral assemblages in pelitic rocks reflect different conditions of 485 metamorphism. It is now recognized that much of the Scottish and Irish Dalradian has 486 experienced what is now termed Barrovian (medium-pressure) regional 487 metamorphism. In addition to the Barrovian (medium-pressure regional 488 metamorphism) zonal scheme, Read (1923) described the Buchan zonal scheme in the 489 NE Scottish Highlands, which represents conditions of low-pressure, high temperature 490 metamorphism (Harte \& Hudson, 1979). Barrovian metamorphism in general postdates 491 the regional D2 deformation (Robertson, 1994; Harte et al., 1984), and the metamorphic 492 zones are not folded by the Tay Nappe. Instead, there is a gradual increase in 493 metamorphic grade from greenschist facies in the southwest to middle-amphibolite 494 facies in the northeast. Maximum P-T conditions in the central Grampian Highlands 495 were $7-8 \mathrm{kbar}, 500-600^{\circ} \mathrm{C}$, while the presence of kyanite-bearing gneissose semipelites 496 in the Central Highland Division (now termed the Badenoch Group) indicates P-T 497 conditions of $7-10 \mathrm{kbar}, 650-800^{\circ} \mathrm{C}$ (Phillips et al., 1999). The relationship between the 498 Buchan and Barrovian-type metamorphism remains contentious. Some workers regard 499 them as essentially contemporaneous (Harte \& Hudson, 1979; Fettes et al., 1976), with 500 a transition between the Buchan and Barrow series while others regard the Buchan501 type metamorphism to predate the Barrovian regional metamorphism (Dempster et al., 502 1995). The low-pressure, high temperature regime of the Buchan metamorphism has 503 been attributed to the heating effects of Lower Ordovician synorogenic intrusions 504 (Harte \& Hudson, 1979; Yardley and Senior, 1982), which are probably subduction505 related (Yardley et al., 1982). In an alternative model for the tectonothermal 506 development of the Buchan Block of the NE Highlands, Viete et al. (2010) proposed that 507 emplacement of the Grampian gabbros and regional metamorphic heating occurred 508 during Grampian syn-orogenic lithospheric-scale extension. Extension followed 509 lithospheric thickening associated with the initiation of Grampian orogenesis and was 510 followed in turn by renewed lithospheric thickening and the termination of extensional 511 heating.

512 The metamorphic evolution of the Irish Dalradian is dominated by the development of 513 Barrovian metamorphic assemblages, although the metamorphic grade varies 514 significantly from place to place. In the NW Mayo Inlier, the metamorphic grade is 515 highest closest to the basement core (the Annagh Gneiss Complex) where it locally 516 reaches the sillimanite zone (Max et al., 1983) and post-dates the development of the 517 main folds (locally F2 in age). The metamorphic grade decreases to the south towards 518 Clew Bay, where the timing of porphyroblast growth took place earlier, post-dating the 519 development of F1 folds. The metamorphic evolution of the Dalradian of the Central Ox 520 Mountains Inlier is similar, with MP3 peak metamorphic conditions ranging from the 
521 staurolite-kyanite zone in the NW to greenschist facies in the SE. The metamorphism in

522 Donegal reached the garnet zone over most of the inlier (Pitcher and Berger, 1972) and

523 generally post-dates the development of F2 folds. The metamorphic grade increases

524 approaching the Lough Derg inlier to the south, as progressively deeper structural

525 levels are exposed through the inverted lower limb of the Ballybofey Nappe (Alsop,

526 1991). Here the metamorphism is in the staurolite-kyanite zone and is structurally

527 later, post-dating the development of F3 folds. However, there are two places in the

528 Dalradian of Ireland where Barrovian metamorphic conditions are not encountered.

529 Adjacent to the voluminous basic and intermediate Ordovician intrusions of south

530 Connemara, migmatitic melting of metasediments has taken place under low-pressure /

531 high temperature conditions, analogous to the Buchan metamorphism of Scotland. This

532 metamorphic event (which postdates the third phase of deformation in Connemara)

533 overprints an earlier phase of regional metamorphism, which was probably in the

534 staurolite-kyanite zone over much of the Connemara Inlier (Yardley, 1976; 1980). The

535 second exception to the prevalence of Barrovian metamorphic conditions is

536 encountered in the southern portion of the NW Mayo Inlier. On southern Achill Island

537 adjacent to the Fair Head - Clew Bay Line, blueschist-facies metamorphism (indicative

538 of high pressure, low temperature metamorphism) occurred (Fig. 6; Gray and Yardley,

539 1979). The MP1 blueschist-facies assemblages developed at P-T conditions of $10.5 \pm 1.5$

540 kbar and $460 \pm 45 \stackrel{\circ}{\circ}$ contemporaneously with the Barrovian metamorphic assemblages

541 to the north (Chew et al., 2003).

542 Grampian magmatism in the Dalradian is restricted to the NE Scottish Highlands and

543 Connemara in western Ireland. Magmatic activity is comprised of syn-orogenic basic

544 and intermediate intrusives and is interpreted as representing the roots of a volcanic

545 arc (e.g. Yardley et al., 1982, Yardley and Senior, 1982; Tanner, 1990). In Connemara,

546 syn-D2 to early D3 basic intrusions have yielded U-Pb zircon ages of 470.1 $\pm 1.4 \mathrm{Ma}$ and

$547474.5 \pm 1$ Ma (Friedrich et al., 1999a). Late D3 quartz-diorite gneisses in the migmatite

548 zone in south Connemara yield U-Pb zircon ages of $463 \pm 4$ Ma (Cliff et al., 1996) and

$549467 \pm 2 \mathrm{Ma}$ (Friedrich et al., 1999b). The post-tectonic Oughterard granite in

550 Connemara has yielded a $462.5 \pm 1.2 \mathrm{Ma}$ U-Pb xenotime age (Fig. 6; Friedrich et al.,

551 1999a). Basic magmatism in NE Scotland yields similar ages to the basic magmatism in

552 Connemara. Dempster et al. (2002) and Carty et al. (2012) report ages of $470 \pm 9$ Ma

553 and $471.3 \pm 0.6 \mathrm{Ma}$ for the post-D2, pre-D3 Insch Gabbro and the syn-D2 Portsoy

554 Gabbro respectively. Oliver et al. (2008) report several U-Pb SIMS zircon ages for the

555 Newer Granites of NE Scotland that cluster at c. 470 Ma. Unlike Connemara, these

556 foliated granites are all two-mica S-types, with $\mathrm{Nd}, \mathrm{Sr}$ and $\mathrm{O}$ isotopic systematics that

557 suggest that they represent melted lower crustal (sedimentary) rocks that formed

558 during peak metamorphism. 
559 Estimates for the closure temperature of the $\mathrm{Sm}-\mathrm{Nd}$ system in garnet range from $\mathrm{c}$. $560600^{\circ} \mathrm{C}$ (Mezger et al., 1992) to c. $850^{\circ} \mathrm{C}$ (Cohen et al., 1988). As Dalradian 561 metamorphism rarely exceeds upper amphibolite facies, the Sm-Nd system in garnet 562 will record garnet growth rather than cooling. Peak metamorphism in the Dalradian is 563 constrained by Sm-Nd garnet ages of 473 - 465 Ma in the type area of Barrovian 564 metamorphism in the Scottish Highlands (Baxter et al., 2002; Oliver et al., 2000), and by 565 Sm-Nd garnet ages of 460 Ma in the Dalradian of NW Ireland (Flowerdew et al., 2000).

566 Mineral cooling ages (typically the ${ }^{40} \mathrm{Ar}-{ }^{39} \mathrm{Ar}$ or $\mathrm{Rb}-\mathrm{Sr}$ methods applied to muscovite, 567 biotite or hornblende) record the post-metamorphic cooling history of an orogenic belt 568 (e.g. Cliff, 1985). Metamorphic mica cooling ages from the Scottish Dalradian such as the 569 classic study of Dempster (1985) and Dempster et al. (1995) show a scatter in age, but 570 most of the data range between 450-460 Ma, which is interpreted as a period of rapid 571 cooling. The oldest Rb-Sr cooling ages of c. 568 Ma for muscovite and c. 505 Ma biotite 572 are inconsistent with a c. 470 Ma Grampian orogeny, and their validity has been 573 questioned (Evans \& Soper, 1997). Recent geochronological studies in the Irish 574 Dalradian (Connemara, NW Mayo and the Ox Mountains) have employed ${ }^{40} \mathrm{Ar}-{ }^{39} \mathrm{Ar}$ and $575 \mathrm{Rb}$-Sr dating on a suite of metamorphic minerals (principally hornblende, biotite and 576 muscovite). These data typically range between 470 - $455 \mathrm{Ma}$ and are consistent with 577 crystallization and subsequent cooling from the Grampian orogenic peak at c. $470 \mathrm{Ma}$ 578 (Friedrich, 1998, 1999b; Flowerdew et al., 2000; Flowerdew, 2000; Chew et al., 2003; 579 Daly and Flowerdew, 2005).

580 Probable para-autochthonous Laurentian terranes - the Tyrone Central Inlier and 581 Slishwood Division in NW Ireland

582 In NW Ireland, two high-grade basement paragneiss terranes, the Tyrone Central Inlier 583 and the Slishwood Division, crop out immediately to the south of the main belt of 584 Dalradian Supergroup rocks (Fig. 2). Their metamorphic and magmatic evolution is 585 substantially different to that of the adjacent lower-grade Dalradian Supergroup rocks 586 to the north, and this led to speculation that they represent exotic terranes (e.g. Max and 587 Long, 1985; Sanders et al., 1987), although more recent research (e.g. Daly et al., 2004; 588 Chew et al., 2008) suggests that both terranes have a Laurentian affinity. Because of 589 their anomalous position, the affinity and tectonic setting of these displaced terranes 590 are of great importance to our understanding of the tectonic evolution of the Grampian 591 orogenic belt, and their geological histories are described in detail below.

592 The Tyrone Central Inlier is the structurally lowest unit within the Tyrone Inlier (Fig. 8). 593 It consists predominantly of a series of high-grade psammitic paragneisses (Hartley 594 1933) in tectonic contact with the other two units of the Tyrone Inlier, an ophiolitic unit 595 (the Tyrone Plutonic Group) and Arenig - Llanvirn arc volcanics and black shales (the 
596

597

598

599

600

601

602

603

604

605

606

607

608

609

610

611

612

613

614

615

616

617

618

619

620

621

622

623

624

625

626

627

628

629

630

631

632

633

634

Tyrone Volcanic Group). The Tyrone Plutonic Group, the Tyrone Volcanic Group and the arc-related intrusive rocks that cut them (Fig. 8) are together referred to as the Tyrone Igneous Complex (Cooper \& Mitchell 2004), and are discussed later in this article. To the north of the inlier, greenschist- to lower amphibolite-facies Dalradian metasediments are separated from the Tyrone Volcanic Group by the Omagh Thrust (Fig. 8).

The Tyrone Central Inlier is structurally overlain by the ophiolite complex (Hutton et al., 1985). The paragneisses of the inlier have undergone polyphase deformation and metamorphism with a primary assemblage in pelitic lithologies of biotite + plagioclase + sillimanite + quartz \pm garnet (i.e. sillimanite zone, below the second sillimanite isograd). Associated with this metamorphic event are abundant leucosomes. The high grade assemblages and leucosomes are cut by post-tectonic pegmatites which post-date at least two deformation fabrics. The leucosomes have yielded a weighted average ${ }^{207} \mathrm{~Pb}$ / $206 \mathrm{~Pb}$ zircon age of $467 \pm 12 \mathrm{Ma}$. The pegmatites have yielded $457 \pm 7 \mathrm{Ma}$ (465 $\pm 7 \mathrm{Ma}$ ) and $458 \pm 7$ (466 Ma $\pm 7 \mathrm{Ma}$ ) Rb-Sr muscovite - feldspar ages (Chew et al., 2008) with the values in parentheses denoting the $\mathrm{Rb}-\mathrm{Sr}$ ages recalculated with the new ${ }^{87} \mathrm{Rb}$ decay constant of $1.3971 \times 10^{-11} \mathrm{a}^{-1}$ of Rotenberg et al. (2012). Biotite from the main fabric in the Tyrone Central Inlier yields a ${ }^{40} \mathrm{Ar}-{ }^{39} \mathrm{Ar}$ age of $468 \pm 1.4 \mathrm{Ma}$, while muscovite from the same pegmatites that have yielded c. $458 \mathrm{Ma}$ (c. $465 \mathrm{Ma}$ ) Rb-Sr ages yields ${ }^{40} \mathrm{Ar}-{ }^{39} \mathrm{Ar}$ ages of $466 \pm 1 \mathrm{Ma}$ and $468 \pm 1 \mathrm{Ma}$ (Chew et al., 2008). Palaeoproterozoic Nd model ages have also been obtained from the paragneisses of the Tyrone Central Inlier. These overlap with Nd model ages obtained from both the Argyll and Southern Highland Groups (Daly and Menuge, 1989). U-Pb detrital zircon analyses from a psammitic gneiss yield age populations at $1.05-1.2,1.5,1.8,2.7$ and 3.1 Ga (Chew et al., 2008) which are ages typical of the Laurentian craton (e.g. Cawood et al., 2003). In situ Hf isotope analysis of zircon rims from c. 470 Ma granitoid rocks that cut the Tyrone Central Inlier paragneisses yield $\varepsilon_{\mathrm{H} f 470}$ values of c. -39. This isotopic signature requires an Archaean source, suggesting that rocks similar to the Lewisian Complex of Scotland occur at depth beneath the Tyrone Central Inlier (Flowerdew et al. 2009). Chew et al. (2008) suggest that the Tyrone Central Inlier is a high-grade metasedimentary terrane of Laurentian (Dalradian?) affinity which has experienced high-grade metamorphism during the Grampian Orogeny, possibly in the roots of a deforming arc. The ophiolite was juxtaposed with the Central Inlier at this time, and the two units were then intruded by a series of stitching tonalitic - granodioritic plutons at 470 - 465 Ma (Cooper et al., 2011) and accompanied by the extrusion of arc lavas. The geological history of the Tyrone Igneous Complex and the Tyrone Central Inlier is substantially different to that of the adjacent Dalradian Supergroup rocks to the northwest which have experienced greenschist-facies metamorphism and no Grampian magmatism. It is probable that the Tyrone Igneous Complex and the Tyrone Central Inlier evolved outboard of the 
635 Laurentian margin during the Grampian Orogeny, and were finally juxtaposed with the 636 margin when the Dalradian was thrust over the Tyrone Inlier during regional SE637 directed D3 thrusting (Alsop and Hutton, 1993).

638 The Slishwood Division is a metasedimentary unit that crops out in the NE Ox 639 Mountains and Lough Derg inliers and the eastern end of the Rosses Point Inlier in NW 640 Ireland (Fig. 9). Gravity (Young, 1974) and magnetic data (Max et al., 1983a) suggest 641 that they are all part of one basement block. The Slishwood Division has long been 642 regarded as pre-Grampian basement (e.g. Max and Long, 1985; Sanders et al., 1987) 643 because of its exceptionally high metamorphic grade, the complex metamorphic and 644 structural history compared with the adjacent Dalradian Supergroup, as well as 645 geochronological evidence. All three inliers are comprised predominantly of migmatitic 646 psammitic gneisses with minor pelites, semipelites, calc-silicates, metabasites and 647 serpentinites which are cut by a suite of granitic pegmatites (Flowerdew et al., 2000), 648 while the NE Ox Mountains Inlier is also cut by several tonalite and granite bodies, 649 possibly subduction-related, that intruded between 471 and 467 Ma (Flowerdew et al., 650 2005).

651 The Slishwood Division records pre-Grampian high-pressure granulite- and earlier 652 eclogite-facies metamorphic events that have not been observed elsewhere in the 653 Dalradian Supergroup rocks of Ireland (Sanders et al., 1987; Flowerdew and Daly, 654 2005). Sanders et al. (1987) recognised an early eclogite-facies metamorphism in the 655 Slishwood area with metamorphic pressures estimated at 12-14 kbar. High-pressure 656 granulite facies assemblages developed at $11 \mathrm{kbar}$ and c. $860^{\circ} \mathrm{C}$ in response to 657 isothermal decompression when original omphacitic clinopyroxene was replaced by 658 sieve-textured plagioclase-augite intergrowths. Subsequently, slow isobaric cooling 659 took place at depth with kyanite replacing sillimanite (Sanders et al., 1987). Flowerdew 660 and Daly (2005) give pressure-temperature estimates of c. $15 \mathrm{kbar}, 800^{\circ} \mathrm{C}$ for the 661 granulite-facies assemblages in the NE Ox Mountains and Lough Derg inliers. Sm-Nd 662 garnet - plagioclase whole-rock isochrons from the granulite-facies assemblages 663 developed in metabasite bodies yield ages of $605 \pm 37$ Ma (Sanders et al., 1987) and 544 $664 \pm 52 \mathrm{Ma}, 539 \pm 11 \mathrm{Ma}, 596 \pm 68 \mathrm{Ma}$ and $540 \pm 50 \mathrm{Ma}$ (Flowerdew and Daly, 2005). The 665 Sm-Nd ages and pressure-temperature estimates are illustrated on Figure 9. In the 666 Lough Derg Inlier some of the metabasite bodies preserve original gabbroic textures, 667 one of which has yielded an igneous clinopyroxene - plagioclase whole-rock isochron of $668580 \pm 36 \mathrm{Ma}$ (Flowerdew and Daly, 2005). This provides a maximum age for the high669 grade metamorphism and suggests that gabbroic magmatism may have been related to 670 extension associated with the opening of the Iapetus Ocean (cf. Bingen et al., 1998). U$671 \mathrm{~Pb}$ detrital zircon ages from Slishwood Division metasedimentary rocks (Daly et al., 672 2004) demonstrate a post-Grenvillian age for deposition of the protolith. 
673 The Slishwood Division differs substantially from the Tyrone Central Inlier as it has

674 experienced eclogite- and granulite-facies metamorphism prior to suturing with the

675 Dalradian Supergroup, while it was also intruded by pre-tectonic basic sills and dykes

676 which are notably absent in the Tyrone Central Inlier. However the subsequent

677 Grampian (i.e. c. 475 - $465 \mathrm{Ma}$ ) histories of the Slishwood Division and the Tyrone

678 Central Inlier are very similar. Both have undergone leucosome generation and

679 subsequent intrusion of pegmatites which cut the high-grade fabrics. The high-grade

680 fabrics in the Slishwood Division are cut by early Grampian tonalite intrusions (Fig. 9)

681 which have yielded U-Pb SIMS zircon ages of $472 \pm 6 \mathrm{Ma}$ and $467 \pm 6 \mathrm{Ma}$ (Flowerdew et

682 al., 2005), similar to the leucosome ages of Chew et al. (2008) from the Tyrone Central

683 Inlier. $\mathrm{Rb}-\mathrm{Sr}$ muscovite ages from the pegmatite suite in both units cluster at around $\mathrm{c}$.

684460 - 455 Ma (Flowerdew et al., 2000, Chew et al. 2008). Final imbrication of the

685 Slishwood Division with the Central Ox Mountains Dalradian occurred during regional

686 SE-directed D3 shearing (Flowerdew et al., 2000), similar to regional SE-directed

687 thrusting of the Dalradian over the Tyrone Inlier along the D3 Omagh Thrust (Alsop and

688 Hutton, 1993).

689 Early Ordovician accretionary complex sequences in the Grampian terrane

690 The suture between the deformed Laurentian margin (Dalradian Supergroup) and the

691 colliding arc (Midland Valley Terrane) is sharply defined by the Highland Boundary

692 Fault in Scotland and the Fair Head - Clew Bay Line in Ireland (Fig. 2). Along this major

693 fault zone a series of Lower Paleozoic deep marine sedimentary rocks and isolated

694 occurrences of mafic and ultramafic rocks crop out, termed the Highland Border

695 Complex in Scotland and the Clew Bay Complex in western Ireland. The Highland

696 Border and Clew Bay Complexes have figured prominently in tectonic reconstructions

697 of the Grampian belt (e.g. Dewey and Mange, 1999), where they are usually regarded as

698 an Early Ordovician accretionary complex.

699 The stratigraphical succession and age of the Highland Border Complex and its

700 relationship to the Dalradian Supergroup have been hotly debated since the late

701 nineteenth century, as the Highland Border Complex is poorly exposed and heavily

702 faulted, way-up indicators are generally absent, and fossils are extremely rare. Models

703 proposed for the Highland Border Complex can broadly be divided into two groups.

704 According to the exotic terrane model (e.g. Curry et al., 1984), the Highland Border

705 Complex first encountered Dalradian rocks in late Silurian-early Devonian times, after

706 the latter had undergone polyphase Grampian (early Ordovician) deformation (Bluck \&

707 Dempster, 1991). In contrast, a recent reinterpretation of the Highland Border Complex

708 (Tanner and Sutherland, 2007) suggests that the majority of the sequence is in

709 stratigraphic continuity with the Dalradian Supergroup, with the exception of the fault-

710 bounded slivers of ophiolitic rocks of the Highland Border Ophiolite (Tanner and 
711 Sutherland, 2007). The exotic terrane model of Curry et al. (1984) was based on their

712 four-fold stratigraphical succession for the Highland Border Complex. Assemblage 1

713 was regarded as the oldest unit in the complex and consists of serpentinite and

714 associated ophiolitic rocks (gabbro and amphibolite). Assemblage 2 consists of

715 carbonate and associated conglomerate, such as the Dounans Limestone near Aberfoyle

716 which has yielded a Lower Arenig trilobite and brachiopod fauna (Curry et al., 1982,

717 1984). Assemblage 3 consists of black shale, chert and quartz wacke. Chitinozoans from

718 the shales have yielded an age range from Upper Arenig to Upper Ashgill (Curry et al.,

719 1984). Assemblage 4 consists of sandstone and conglomerate such as the Achray

720 Sandstone and the Margie Series of the North Esk. Two distinct generations of

721 chitinozoa were obtained from the Achray Sandstone at Lime Craig Quarry near

722 Aberfoyle (Curry et al., 1984) - a reworked, blackened and flattened Llanvirn-Llandeilo

723 fauna along with younger, undamaged Caradoc-Ashgill taxa, suggesting that the

724 Highland Border Complex had undergone pre-Caradoc deformation and low-grade

725 metamorphism prior to the deposition of assemblage 4. Tanner and Sutherland (2007)

726 reinvestigated the stratigraphical succession and chitinozoan faunas of Curry et al.

727 (1984). They found no evidence that sedimentary rocks of proven age younger than

728 Arenig occur in the Highland Border Complex and that the 'ophiolite' lies structurally on

729 top of the Highland Border Complex and not at the base as previously thought (Curry et

730 al. 1984). Their model (Figs. 3,10) is much simpler, with the Highland Border Ophiolite

731 dividing the Complex into an older portion in continuity with the Dalradian (termed the

732 Trossachs Group) and an upper sequence comprising the obducted ophiolite and its

733 cover (the Garron Point Group). The Laurentian provenance of detrital zircons within

734 the Trossachs Group reinforces its linkage with the Dalradian Supergroup (Cawood et 735 al. 2012).

736 The Clew Bay Complex in western Ireland comprises a series of low-grade turbiditic 737 metasediments which have been interpreted as representing an accretionary complex 738 (e.g. Dewey and Mange, 1999). On Clare Island, the Clew Bay Complex comprises 739 graphitic mudrocks, spilites, greywackes and micro-conglomerates with clasts of vein 740 quartz, schist, gneiss, and granite. The nature of the deformation in these rocks is 741 difficult to ascertain. Chew (2003) concluded that the Dalradian and the Clew Bay 742 Complex on the island of Achill Beg (Fig. 6) share the same polyphase structural history 743 across the Achill Beg Fault. This model is therefore similar to the model of Tanner and 744 Sutherland (2007) who favour stratigraphic continuity of the Highland Border Complex 745 with the Dalradian Supergroup. An alternative interpretation of the structure of parts of 746 the Clew Bay Complex is given by Max (1989) who reinterpreted it to be largely 747 tectono-sedimentary in origin (i.e. a chaotic mélange), with blocks of greywacke up to 748 8m across floating in a black mudstone matrix. A Middle Cambrian - Early Ordovician 749 sponge (Protospongia hicksi, Rushton \& Phillips, 1973) and Early - Middle Ordovician 
750

751

752

753

754

755

756

757

758

759

760

761

762

763

764

765

766

767

768

769

770

771

772

773

774

775

776

777

778

779

780

781

782

783

784

785

786

coniform euconodonts (Harper et al., 1989) have been obtained from the Clew Bay Complex. Chew et al. (2003) estimated metamorphic temperatures of $325-400^{\circ} \mathrm{C}$ and pressures of $10 \mathrm{kbar}$ for the Clew Bay Complex, which is similar to the high-pressure low-temperature metamorphic conditions experienced by the blueschist-facies Dalradian rocks to the north while metamorphic cooling ages from ${ }^{40} \mathrm{Ar}-{ }^{39} \mathrm{Ar}$ ages from metamorphic muscovite cluster at c. $470 \mathrm{Ma}$ (Chew et al., 2010).

\section{Midland Valley Terrane}

The Midland Valley terrane consists of Late Cambrian - Early Ordovician suprasubduction ophiolite complexes such as Shetland to the north of mainland Scotland, Ballantrae in SW Scotland, Tyrone in NW Ireland and Clew Bay in western Ireland (Figs 2, 6; note most of the Midland Valley terrane is covered by younger Middle-Ordovician to Permo-Triassic sediments that are not differentiated on Fig. 2.). It also contains fragments of the Grampian volcanic arc and its associated fore-arc basin, such as the Lough Nafooey arc and South Mayo Trough in western Ireland (Fig. 6). The eroded remnants of the Grampian orogen are overlain by Silurian successor basins.

\section{Late Cambrian - Early Ordovician supra-subduction ophiolite complexes}

The Grampian arc-continent collision event resulted in the obduction of suprasubduction zone ophiolites onto the Laurentian margin (Dewey \& Shackleton, 1984). Several Late Cambrian - Early Ordovician suprasubduction ophiolite complexes are preserved on the Laurentian margin of Scotland and Ireland and can be divided into two belts. A northwestern belt occurs in close proximity to the Highland Boundary Fault Fair Head - Clew Bay Line, and includes the ophiolitic rocks of Unst, Shetland, Bute in SW Scotland, and a series of smaller fault-bounded slivers of ophiolitic mélange comprising the Highland Border ophiolite. A southeastern belt is represented by the ophiolitic rocks of the Ballantrae Igneous Complex that is likely to have been obducted from a different suture now buried underneath younger rock units of the Southern Uplands - Longford Down Terrane (Fig. 2). Although geographically part of the northwestern belt of ophiolite complexes, the geochronological constraints on the ophiolitic rocks of the Tyrone Plutonic Group suggest it may be associated with the Ballantrae Igneous Complex (Figs. 3, 11).

The Shetland ophiolite is exposed in the northeast extension of the Grampian Terrane on the islands of Unst and Fetlar (Fig. 2). It occurs in two thrust sheets, probably part of a downfolded klippe, that overlie Dalradian metasedimentary rocks (Flinn, 1985, 2000). The most complete succession is within the lower sheet and is $7 \mathrm{~km}$ thick. From the base upwards it comprises a metamorphic sole, peridotite, dunite, pyroxenite and gabbro. The peridotite and the dunite are heavily serpentinized but have attracted widespread interest because of the concentration of platinum-group elements (e.g. 
787 Prichard \& Lord, 1993; O’Driscoll et al., 2012). Only the lower parts of the classic

788 'Penrose' ophiolite succession are definitively preserved. Minor dykes that cut the 789 gabbro unit have been interpreted as representing the lower levels of a possible sheeted 790 dyke complex (Flinn 1985; Prichard 1985). Geochemical analyses of the dykes indicate 791 that they have basaltic island-arc affinities, with some high-Mg members classified as 792 boninites (Gass et al. 1982; Moffat 1987; Spray 1988). No contiguous pillow lavas are 793 present. A U-Pb TIMS zircon age of $492 \pm 3$ Ma obtained from a plagiogranite within the 794 gabbro unit dates crystallization of the complex (Spray \& Dunning, 1991). The gabbro in 795 the lower thrust sheet is overlain unconformably by low-grade meta-siltstones with 796 occasional metavolcanic rocks and conglomerate layers. The conglomerate layers 797 include clasts that can be matched with distinctive lithologies in the ophiolite, including 798 gabbro, quartz-albite porphyry and albite-granite. The sedimentary cover to the 799 ophiolite is believed to have been derived from erosion of the ophiolite nappes as they 800 emerged above sea-level (Flinn, 1958), but no geological relationships preclude 801 deposition on the sea-floor prior to obduction. In the east of Fetlar, the lower ophiolite 802 sheet is also overlain unconformably by the enigmatic Funzie conglomerate of Fetlar 803 (Flinn 1956) which is dominated by quartzite clasts, the provenance of which are 804 uncertain. K-Ar hornblende ages obtained from the metamorphic sole range between c. 805479 and c. $465 \mathrm{Ma}$ and are interpreted to broadly date obduction (Spray, 1988).

806 The Highland Border Ophiolite (Tanner and Sutherland, 2007; Tanner 2007) forms a 807 discontinuous belt of mafic and serpentinized ultramafic rocks along the Highland 808 Boundary Fault from Bute to Stonehaven (Fig. 10). Some of the serpentinized ultramafic 809 rock slivers are believed to have been produced by exhumation of serpentinized sub810 continental lithospheric mantle within the extending, distal portions of the Laurentian 811 margin during the opening of the Iapetus Ocean (Chew 2001, Tanner 2007; Henderson 812 et al., 2009) which were then incorporated into the ophiolitic mélange during the onset 813 of collision. However at least two localities along the Highland Boundary fault zone 814 (Scalpsie Bay on Bute and at Aberfoyle) expose a thick, locally developed 'sole' of 815 amphibolite (Henderson and Robertson, 1982) of significantly higher metamorphic 816 grade than the local Highland Border Complex or Dalradian Supergroup rocks. These 817 amphibolites are believed to represent the metamorphic sole of a classic 'Penrose' 818 ophiolite (Penrose conference participants, 1972). The peak metamorphic assemblage 819 at Scalpsie Bay on Bute is hornblende, garnet and titanite (Henderson and Roberston, 820 1982). Magmatic zircons from the Bute amphibolite define a $499 \pm 8 \mathrm{Ma}$ U-Pb Concordia 821 age, interpreted as dating the crystallization of its igneous protolith and therefore the 822 formation of this part of the Highland Border Ophiolite (Chew et al., 2010). Garnet, 823 titanite, amphibole and the whole rock define a $546 \pm 42 \mathrm{Ma}$ Sm-Nd isochron, while the 824 amphibole has yielded a $537 \pm 11 \mathrm{~K}$-Ar age (Dempster and Bluck, 1991). More recent 825 constraints of the age of metamorphism include a $490 \pm 4 \mathrm{Ma}{ }^{40} \mathrm{Ar}-{ }^{39} \mathrm{Ar}$ hornblende age 
826 from the Bute amphibolite, and a $488 \pm 1$ Ma ${ }^{40} \mathrm{Ar}-{ }^{39} \mathrm{Ar}$ muscovite age from a 827 metasedimentary xenolith within it, from which P-T estimates of $5.3 \mathrm{kbar}$ and $580{ }^{\circ} \mathrm{C}$ 828 relate to ophiolite obduction (Chew et al., 2010). A homogenous zircon age population 829 from this metasedimentary xenolith intercalated within the ophiolite defines a U-Pb 830 Concordia age of $490 \pm 4 \mathrm{Ma}$. This date is interpreted to suggest a volcaniclastic origin 831 for this rock, possibly sourced from a subduction-related magmatic arc founded on 832 ophiolitic basement (Chew et al., 2010).

833 The high-grade Deer Park Complex is the correlative of the Highland Border Ophiolite in 834 western Ireland (Fig. 6). It consists of a mélange of serpentinite, amphibolite and slivers 835 of metasediment in tectonic (faulted) contact with the low-grade accretionary complex 836 rocks of the Clew Bay Complex (Phillips, 1973). The amphibolites within the Deerpark 837 Complex have a Mid Oceanic Ridge Basalt (MORB)-like trace element chemistry, but 838 pronounced $\mathrm{Nb}$ anomalies and neodymium isotopic compositions that are consistent 839 with a juvenile subduction-related origin (Chew et al., 2010). The amphibolites and 840 serpentinites have been interpreted by Ryan et al. (1983) as representing a 841 dismembered ophiolite. Detrital zircon $\mathrm{U}-\mathrm{Pb}$ data from slivers of metasedimentary rock 842 within the Deerpark Complex ophiolitic mélange suggest these metasediments are 843 identical to the Dalradian Supergroup. They are interpreted as deepwater sediment on 844 the seafloor of the Laurentian continent which was then caught up by obduction of the 845 ophiolite (Chew et al., 2010). The "cooling" ages of metamorphic minerals in the 846 Deerpark Complex range from c. $480 \mathrm{Ma}\left(\mathrm{Rb}-\mathrm{Sr}\right.$ and ${ }^{40} \mathrm{Ar}-{ }^{39} \mathrm{Ar}$ ages from metamorphic 847 muscovite in the metasedimentary slivers) to c. $515 \mathrm{Ma}$ (a ${ }^{40} \mathrm{Ar}-{ }^{39} \mathrm{Ar}$ hornblende age 848 from an amphibolite) which are significantly older than the c. 470 - 455 Ma 849 metamorphic mineral ages recorded from the Dalradian and low-grade Clew Bay 850 Complex rocks to the north (Chew et al., 2010). The pressure - temperature conditions 851 in the Deerpark Complex are also different to the low-temperature, high-pressure 852 assemblages found in the Dalradian and Clew Bay Complex rocks, yielding estimates of 853 c. $580^{\circ} \mathrm{C}, 3.3 \mathrm{kbar}$ (i.e. shallower and hotter).

854 The ophiolitic affinity of the high-grade metabasites and serpentinites of the Deerpark 855 Complex and Highland Border Ophiolite means that they figure prominently in tectonic 856 models of the Grampian Orogeny (e.g. Dewey and Mange, 1999), with the low-grade 857 turbidites of the Clew Bay and Highland Border complexes interpreted as accretionary 858 complexes and the Deerpark Complex and Highland Border Ophiolite representing a 859 dismembered supra-subduction ophiolitic mélange. The metamorphic pressure860 temperature estimates from the Clew Bay Complex and Deerpark Complex in western 861 Ireland are consistent with this scenario, as the accretionary complex rocks of the Clew 862 Bay Complex have experienced high-pressure, low temperature metamorphic 863 conditions (c. $10 \mathrm{kbar}, 325-400^{\circ} \mathrm{C}$, Chew et al., 2003) as would be expected in a 
864 subduction zone environment, while the ophiolitic rocks of the Deerpark Complex have

865 experienced high-temperature, low-pressure metamorphic conditions typical of the 866 metamorphic sole of an obducted ophiolite.

867 The Ballantrae Igneous Complex occurs towards the southern margin of the Midland 868 Valley Terrane in SW Scotland and comprises two main rock associations (Figs 2, 11). 869 The first is the volcano-sedimentary Balcreuchan Group (Smellie \& Stone, 2001) that 870 comprises basalt pillow lavas, agglomerates, tuffs, sandstones, black shales and cherts 871 (Fig. 11). An early to late Arenig age is indicated by graptolite faunas. Geochemical 872 studies have suggested a variety of different tectonic settings for these lavas including 873 mid-ocean ridge, within-plate and island arc environments (e.g. Wilkinson \& Cann, 874 1974; Thirlwall \& Bluck, 1984; Smellie \& Stone, 2001). The second association consists 875 of serpentinized peridotite and harzburgite with minor gabbro and trondhjemite, and 876 possible sheeted dykes (Fig. 11). Although lithological contacts are highly faulted, the 877 overall association of rock types has led to general acceptance that they form part of a 878 dismembered ophiolite. Isotopic ages broadly complement the faunal data. Two island879 arc lavas have whole-rock Sm-Nd ages of 476 $\pm 14 \mathrm{Ma}$ and $501 \pm 12 \mathrm{Ma}$ (Thirlwall \& 880 Bluck 1984), and a gabbro of within-plate affinity has yielded a K-Ar age of $487 \pm 8 \mathrm{Ma}$ 881 (Harris et al. 1965). Olistrostromes and mélanges within the complex contain blocks of 882 material that preserve evidence for subduction-related metamorphism. These include 883 garnet pyroxenites metamorphosed at $10-13 \mathrm{~kb}$ and $900-950^{\circ} \mathrm{C}$ (Treloar et al. 1980) 884 and blueschist-facies rocks. Sm-Nd isochron ages of $576 \pm 32 \mathrm{Ma}$ and $505 \pm 11$ Ma have 885 been obtained from the garnet pyroxenites (Hamilton et al. 1984). A K-Ar age of $478 \pm 8$ 886 Ma (Llanvirn) obtained from the metamorphic sole probably dates obduction (Bluck et 887 al. 1980). The age of unconformably overlying sedimentary rocks indicates that the 888 ophiolite was obducted and eroded by middle Llanvirn (c. $465 \mathrm{Ma}$ ) times.

889 The ophiolitic rocks of the Tyrone Plutonic Group form the southern, structurally lower 890 portion of the Tyrone Igneous Complex (Fig. 8) and consist of a unit of gabbros and 891 dolerites. The gabbros exhibit cumulate layering and are overlain by a sheeted dolerite 892 dyke complex which exhibits classic one-sided chilled margins (Hutton et al., 1985). 893 Pillow lavas are scarce within the group, and are only present as a roof-pendant within 894 the Craigballyharky tonalite intrusion. Geochemistry has shown the sequence to be of 895 suprasubduction affinity (Draut et al. 2009), with positive $\mathrm{Pb}$, negative $\mathrm{Nb}$ and modest 896 Ti anomalies (Cooper et al., 2011). Based on a magma-mixing relationship between 897 gabbro and tonalite at Craigballyharky, Hutton et al. (1985) considered the ophiolitic 898 rocks of the Tyrone Plutonic Group to be contemporaneous with the $472+2 /-4$ Ma 899 Craigballyharky tonalite. This U-Pb zircon age was thus taken to represent the age of 900 the ophiolite and the timing of ophiolite obduction (Hutton et al. 1985). Cooper et al. 901 (2011) presented a U-Pb zircon age of 479.6 \pm 1.1 Ma for an olivine gabbro from the 
902 Tyrone Plutonic Group which displays cumulate layering. Two zircon fractions gave 903 inherited ages of c. $1015 \mathrm{Ma}$ and $2100 \mathrm{Ma}$, which were attributed by Cooper et al. 904 (2011) to possibly reflect subduction of peri-Laurentian metasediments under the 905 Tyrone ophiolite during its formation.

906

907 The colliding volcanic arc terrane and its associated fore-arc basin

908 During closure of the Iapetus Ocean, subduction of Iapetus oceanic lithosphere resulted 909 in the formation of an Early Ordovician intra-oceanic arc. In Scotland this Early 910 Ordovician arc is inferred to lie beneath the Middle Ordovician - Permo-Triassic 911 sedimentary cover of the Midland Valley graben between the Highland Boundary and 912 Southern Uplands faults (Fig. 2). The basement to the Midland Valley Terrane (MVT) is 913 known only from xenolith suites entrained within Carboniferous volcanic rocks and 914 comprises both mafic and felsic granulite-facies metamorphic rocks along with rare 915 granulite-facies metasedimentary xenoliths (Upton et al., 1976). The MVT basement 916 xenoliths yield Sm-Nd model ages of 0·6-1·8 Ga (Halliday et al., 1993). Zircons from one 917 of the rare relict metasedimentary xenoliths have yielded early Proterozoic ( $>2 \mathrm{Ga}$ ) bulk 918 fraction $\mathrm{U}-\mathrm{Pb}$ upper intercept ages, indicating the presence of old detritus in the 919 sedimentary precursor (Halliday et al., 1984). However a younger detrital zircon 920 population, possibly derived from an early Ordovician - middle Silurian magmatic arc, is 921 also present ruling out a Precambrian depositional age (Badenszki et al., 2011). The 922 timing of granulite-facies metamorphism is well constrained at $391 \pm 6$ Ma (Middle 923 Devonian) by analyses of a petrographically distinct population, sometimes occurring as 924 overgrowths on older grains (Badenszki et al., 2011).

925 In Ireland, Early - Middle Ordovician arc volcanics are exposed to the south of the Fair 926 Head - Clew Bay Line (Fig. 2) in western Ireland (the Lough Nafooey arc) and in the 927 north of Ireland (the Tyrone Volcanic Group; Figs 2, 8). The Lough Nafooey arc is 928 exposed in a series of small, fault-bounded inliers and may form some of the basement 929 to the Grampian fore-arc basin (the South Mayo Trough). As arc volcanism spans the 930 Grampian arc-continent collision event, the chemistry of the arc volcanics can be used 931 to constrain the onset of collision. The oldest (pre-collisional) arc volcanics include the 932 lower portions of the Late Tremadoc Lough Nafooey Group and the Bohaun Volcanic 933 Succession (Fig. 6). The age of the basaltic lavas of the Bohaun Volcanic Succession is 934 not known, but their boninitic chemistry (Clift and Ryan, 1994) and strongly positive $935 \varepsilon N d(t)$ values (Fig. 12) could indicate earliest-stage formation above a young 936 subduction zone. The light rare earth element (LREE) depletion and strongly positive $937 \varepsilon N d(t)$ values of the tholeiitic basalts of the basal Lough Nafooey Group (Fig. 12) and the 938 lack of continental detritus in the oldest sediments of that group also suggest an origin 
939 far from the Laurentian margin (Ryan et al., 1980), while younger volcanic units exhibit 940 a trend toward higher silica, higher-K compositions with increasing LREE enrichment 941 (Ryan et al., 1980) and lower $\varepsilon N d(t)$ values (Fig. 12). Plagiogranite boulders in the basal 942 portions of the overlying Silurian succession are unequivocally derived from the 943 underlying Lough Nafooey Group and two clasts have yielded U-Pb SIMS zircon ages of $944489.9 \pm 3.1 \mathrm{Ma}$ and $487.8 \pm 2.3 \mathrm{Ma}$ (Chew et al., 2007). Nd isotopic evidence 945 demonstrates that the plagiogranites had assimilated some old continental crust, and 946 therefore the arc volcanics were tapping subducting Laurentian margin sediments by 947490 Ma. The Arenig Tourmakeady Volcanic Group contains andesitic and rhyolitic tuffs 948 and volcaniclastic sediments (Graham et al., 1989). These volcanics are LREE enriched, 949 and have strongly negative $\varepsilon \mathrm{N}_{\mathrm{d}(\mathrm{t})}$ values indicating substantial assimilation of old 950 continental material (Fig. 12). The Tourmakeady Volcanic Group is believed to span 951 'hard' arc-continent collision (i.e. orogeny and regional deformation: Draut and Clift, 952 2001). Volcanic horizons within the the South Mayo Trough include andesitic tuffs and 953 ignimbrites of the Rosroe Formation and ignimbritic tuffs of the Llanvirn Mweelrea 954 Formation. These are interpreted as syn- to post-collisional arc volcanics, and are LREE955 enriched, with strongly negative $\varepsilon N d(t)$ values (Fig. 12). The lowermost ignimbrite 956 horizon within the Mweelrea Formation has yielded a U-Pb zircon age of 464.4 $\pm 3.9 \mathrm{Ma}$ 957 (Dewey and Mange, 1999).

958 The South Mayo Trough is interpreted as a fore-arc basin that developed between the 959 accretionary complex rocks of the Clew Bay Complex and the South Mayo volcanic arc 960 (e.g. Dewey and Mange, 1999; Fig. 6). Although many of the basal contacts are either not 961 exposed or are faulted, the sediments in the basin were presumably deposited on the 962 Early Ordovician arc volcanics of South Mayo. The basin fill of the South Mayo Trough 963 (formally known as the Murrisk Group) consists of a series of predominantly deep 964 marine volcaniclastic rocks and tuffs that shallows upwards. The South Mayo Trough is 965 of critical importance in understanding the evolution of the Grampian Orogeny. This is 966 because the basin was not inverted during the arc- continent collision event, but was 967 merely buckled into a large fold, commonly known as the Mweelrea Syncline. It 968 preserves sediment received from the deforming and unroofing orogen, and also 969 volcanic detritus from the South Mayo arc. Whole rock geochemistry demonstrates that 970 the lower portions of the northern limb of the South Mayo trough are derived from a 971 source enriched in $\mathrm{Mg}, \mathrm{Cr}$, and $\mathrm{Ni}$ indicative of an ultramafic (ophiolitic) source region 972 (Wrafter \& Graham, 1989). This prominent ultramafic signature decreases up sequence, 973 as does the abundance of detrital chrome spinel (Fig. 13). The drop in detrital chrome 974 spinel abundance coincides with a sudden influx of metamorphic detritus (garnet, 975 staurolite, sillimanite and muscovite) (Dewey \& Mange, 1999). These data suggest the 976 progressive unroofing of an ophiolite complex in the Arenig followed by the exhumation 977 of the Grampian metamorphic belt during the middle Ordovician (Wrafter \& Graham, 
978 1989, Dewey \& Mange, 1999). Detrital geochronology studies including U-Pb dating of

979 zircons and Ar-Ar dating of white mica have revealed that the South Mayo Trough was

980 derived from igneous and metamorphic complexes in Laurentia. U-Pb zircon ages

981 cluster around three important periods of crustal evolution; the Lewisian (Archaean),

982 Grenville orogeny (Mesoproterozoic) and Grampian orogeny (Ordovician) (McConnell

983 et al. 2009; Clift et al. 2009; Mange et al. 2010).

984 Despite their important role in the arc-continent collision that produced the Grampian 985 orogeny, the arc volcanics and fore-arc sediments of South Mayo are relatively 986 undeformed. The Lough Nafooey Group, which is thought to lie underneath the $6 \mathrm{~km}$ of 987 sediments that fill the South Mayo Trough, has experienced very low-grade (prehnite988 pumpellyite facies) metamorphism (Ryan et al., 1980). This suggests that South Mayo 989 did not undergo substantial tectonic burial during the Grampian Orogeny. In particular, 990 the allochthonous position of the Connemara terrane with respect to the rest of the 991 Laurentian margin cannot be explained by simple southwards thrusting of this terrane 992 over the very low-grade arc and fore-arc basins of South Mayo.

993 The predominantly extrusive rocks of the Tyrone Volcanic Group form the upper part of 994 the Tyrone Igneous Complex and consist of basaltic pillow lavas and andesitic to 995 rhyolitic lavas along with banded cherts, ironstones and mudstones (Cooper \& Mitchell 9962004 and references therein). The mudstone units have yielded graptolite fragments of 997 Arenig-Llanvirn age (Hutton \& Holland, 1992). More recently, Cooper et al. (2008) 998 document the presence of Isograptus victoriae lunatus in graptolitic mudstones from 999 Slieve Gallion, along with a U-Pb zircon age of $473 \pm 0.8$ Ma for an extrusive rhyolite 1000 that sits stratigraphically below the graptolitic mudstones. There is evidence for at least 1001 three volcanic cycles within the Tyrone Volcanic Group, each commencing with basaltic 1002 lavas, with cycle tops characterized by the presence of laminated chert and/ or 1003 mudstone (Hutton et al. 1985; Cooper \& Mitchell 2004). The basalts, andesites and 1004 rhyolites are typically LILE- and LREE-enriched with variable negative $\mathrm{Nb}$ anomalies 1005 (Cooper et al., 2011; Draut et al. 2009). A suite of calc-alkaline, arc-related intrusive 1006 rocks range in age from $470.3 \pm 1.9 \mathrm{Ma}$ to $464.3 \pm 1.5 \mathrm{Ma}$ and cut both the Tyrone 1007 Igneous Complex and the Tyrone Central Inlier (Cooper et al., 2011). They have 1008 geochemical affinities similar to the LILE- and LREE-enriched rhyolites and andesites of 1009 the Tyrone Volcanic Group (Cooper et al., 2011; Draut et al. 2009). Draut et al. (2009) 1010 suggested that the light REE (LREE)-enriched island-arc signatures of the volcanics and 1011 intrusive rocks of the Tyrone Igneous Complex were produced by an oceanic arc that 1012 assimilated considerable detritus from the Laurentian margin. The component of 1013 continentally derived material was observed to increase up sequence, similar to the 1014 transition from primitive intra-oceanic arc magmatism to magmatism with substantial 1015 assimilation of Laurentian material observed in the Lough Nafooey arc of western 
1016 Ireland (Draut et al., 2004). Hollis et al. (2012) suggest the Tyrone Volcanic Group

1017 represents an evolving peri-Laurentian island-arc/backarc which underwent several 1018 episodes of intra-arc rifting prior to its accretion at ca. $470 \mathrm{Ma}$ to an outboard peri1019 Laurentian microcontinental block (the Tyrone Central Inlier). The accretion of the 1020 Tyrone arc and its associated suprasubduction-zone ophiolite was inferred to represent 1021 the final of three stages of arc-ophiolite emplacement onto the Laurentian margin 1022 recognized both in the Scottish and Irish Caledonides and the Newfoundland 1023 Appalachians.

1024 Studies of crustal magnetization and high-level granite geochemistry in the Midland 1025 Valley and Southern Uplands - Longford Down terranes (Kimbell \& Stone, 1995; Stone 1026 et al., 1997) suggest that a hidden crustal block is located beneath an allochthonous 1027 Southern Uplands Terrane. Armstrong \& Owen (2001) termed this block 'Novantia' (Fig. 1028 14) and equated it with the Annieopsquotch Accretionary Tract (ophiolite-arc terrane) 1029 of Newfoundland. They proposed that the accretion of this block in the Arenig to the 1030 southern margin of the Midland Valley Terrane was associated with obduction of the 1031 Ballantrae Igneous Complex (Fig. 14).

1032 Silurian inter-arc sedimentation in the Midland Valley terrane

1033 A series of geographically separate Silurian successions within the Midland Valley 1034 terrane contain evidence for contemporaneous volcanism and are inferred to have 1035 accumulated in inter-arc basins above a north-dipping subduction zone (Bluck 2002; 1036 Holland 2009 and references therein). In western Ireland, Silurian sediments rest 1037 unconformably on a range of older rocks that had been exhumed following the 1038 Grampian orogeny. The most complete succession in North Galway unconformably 1039 overlies the Dalradian of Connemara and the Ordovician sediments and volcanics of the 1040 South Mayo Trough. The $3 \mathrm{~km}$ thick succession is Llandovery to Wenlock in age and 1041 accumulated in a range of fluvial, shallow marine and shelf environments. In the 1042 Midland Valley terrane of Scotland, Silurian rocks are only observed to rest 1043 unconformably on older rocks in the Girvan inlier where they overlie Mid- to Late 1044 Ordovician sediments. Elsewhere, the stratigraphic bases of the local Silurian 1045 successions are unexposed. In most of the Scottish inliers, Llandovery marine turbidite 1046 sequences pass up into Wenlock fluvial sediments that include distinctive southerly1047 derived alluvial fan conglomerates (Bluck 1983, 1984). These include clasts of volcanic 1048 and plutonic igneous rocks, as well as a rangle of sedimentary and metasedimentary 1049 lithologies. Detrital zircons obtained from the Silurian rocks in Scotland have a very 1050 similar age distribution, irrespective of whether the samples were derived from the 1051 south or north (Phillips et al., 2009). The bimodal age distribution comprises an Arenig1052 Llanvirn (c. $475 \mathrm{Ma}$ ) component, probably derived from a mixed ophiolite-volcanic1053 plutonic source (presumably the Midland Valley arc and the Ballantrae-Tyrone 
1054 ophiolites), and a Mesoproterozoic (c. 1 Ga) component. The latter could have been

1055 derived from the now-unexposed basement of the Midland Valley terrane.

1056 Successor sedimentary basins: the Girvan fore-arc and the Southern Uplands1057 Longford Down terrane accretionary prism

\section{The Girvan fore-arc}

1059 A succession of mainly clastic sedimentary rocks, c. $2.6 \mathrm{~km}$ thick, was deposited 1060 unconformably upon the Ballantrae Igneous Complex in Llanvirn-Ashgill times 1061 (Williams, 1962; Ingham, 1978; Bluck, 1983; Ince, 1984; Bluck, 2002). It is viewed as 1062 having accumulated in a fore-arc basin that developed after the accretion of the 1063 Grampian arc to the Laurentian margin and a switch in the polarity of subduction to 1064 northward-directed (Bluck, 2002 and references therein). The Girvan succession was 1065 deposited in fluvio-deltaic and marine environments and the bulk of sedimentation was 1066 controlled by displacement on normal faults with downthrow to the southeast. The 1067 succession is historically important as its rich Laurentian faunal assemblages were 1068 amongst the first to be compared with those of the Appalachians (Reed, 1935). It has 1069 assumed further importance in regional tectonic models because of provenance studies 1070 focused on the wide range of igneous and metamorphic detritus contained within major 1071 conglomerate units. These were deposited in a range of fluvial to submarine fan 1072 environments by southeast-flowing palaeocurrents. They contain basic and ultrabasic 1073 clasts, derived most probably from the Ballantrae Igneous Complex, as well as acid to 1074 intermediate igneous clasts, including hornblende-biotite granite. These clasts have a 1075 calc-alkaline chemistry and their size (some $>1 \mathrm{~m}$ in diameter) indicates a proximal 1076 source within the Midland Valley. $\mathrm{Rb}-\mathrm{Sr}$ ages derived from these clasts are imprecise 1077 but consistent with more or less continuous Cambrian to Ordovician magmatism 1078 (Longman et al., 1979; Bluck, 1983). The oldest clasts could have been derived from the 1079 remnant arc that collided with the Laurentian margin during the early Ordovician, and 1080 the younger clasts likely represent the continuation of magmatic activity following a 1081 switch in subduction polarity (Bluck, 2002). Detrital garnet was derived from a number 1082 of sources, including a Barrovian metamorphic terrane which has been argued to be the 1083 uplifted and eroded Dalradian Supergroup (Hutchison \& Oliver 1998).

\section{The Southern Uplands accretionary prism}

1085 South of the Southern Uplands Fault, the Southern Uplands-Longford Down terrane 1086 comprises Ordovician and Silurian sedimentary rocks that are interpreted as an 1087 accretionary prism developed above a northwest-dipping subduction zone (Leggett et 1088 al., 1979; Leggett, 1987; Oliver et al., 2002 and references therein). The Arenig age of 1089 the oldest sedimentary rocks is consistent with initiation of subduction shortly after the 1090 Grampian orogenic event. In Scotland, the terrane comprises three fault-bounded units, 
1091 the Northern, Central and Southern Belts; the Northern and Central belts probably

1092 extend laterally into Ireland. Each is divided into individual tracts a few kilometres wide 1093 and bounded by major reverse faults (Fig. 15). The sediments are all steeply dipping 1094 and strongly folded, but the overall younging direction within each tract is towards the 1095 northwest. Each fault-bounded tract is interpreted as a slice of ocean plate sedimentary 1096 cover that was detached during subduction from the down-going oceanic lithosphere 1097 and added to the leading edge of the accretionary prism (Fig. 15).

1098 The Ordovician rocks of the Northern Belt consist of basal sequences of lava and chert 1099 (Crawford Group) and black shale (Moffat Shale Group) which were gradually buried 1100 under a southeast-prograding wedge of clastic turbidites (Leadhills Supergroup) 1101 deposited as large-scale submarine fans. The basal lavas (Arenig-Llanvirn) have diverse 1102 origins with possible MORB, within-plate and ocean island lavas and perhaps arc1103 related rocks all present (Oliver et al., 2002). In situ Caradoc volcanic rocks are mainly 1104 within-plate and ocean-island types (Phillips et al., 1995). Major conglomerate horizons 1105 derived from the northwest are dominated by clasts, some up to 1-1.5 metres in 1106 diameter, of hornblende-biotite granite (Elders, 1987). The size of the clasts implies a 1107 proximal source, thought to be the Ordovician magmatic arc that is presumed to 1108 underlie much of the nearby Midland Valley Terrane (Bluck, 1983). Dating of detrital 1109 muscovite and garnet from sandstone turbidites has yielded isotopic ages mostly in the 1110 range 480-460 Ma, consistent with derivation from the Dalradian Supergroup which 1111 was being exhumed to the northwest following the Grampian orogenic event (Kelley \& 1112 Bluck, 1989; Hutchinson \& Oliver, 1998).

1113 The pattern of sedimentation established in the Northern Belt continues through the 1114 Central and Southern belts with only minor differences (Fig. 15). The Central Belt is 1115 dominated by thick successions of Silurian greywacke sandstones and minor 1116 conglomerates deposited in submarine fans. The influx of sandstones occurred 1117 diachronously southwards through the Llandovery and possibly into the Wenlock. 1118 Palaeocurrents are often southwest-directed and interpreted as axial flows along the 1119 strike of the basin (Kelling et al., 1987). High levels of ultrabasic and basic elements in 1120 some turbidites imply derivation from ophiolites. Conglomerates carry a similar clast 1121 suite to those of the Northern Belt, although the maximum clast size is $30 \mathrm{~cm}$ and granite 1122 clasts represent a much smaller proportion of the total clast suite. The Southern Belt is 1123 composed entirely of Wenlock greywacke sandstones.

1124 A similar structural evolution is recorded throughout the terrane. The main phase of 1125 deformation is associated with southeast-vergent thrusting/reverse faulting and folding 1126 (e.g. Leggett et al., 1979; Stone, 1995). Deformation may have initiated in partly-lithified 1127 sediments and progressed into prehnite-pumpellyite grade conditions during cleavage 1128 development. Evidence that deformation and metamorphism of the older parts of the 
terrane was contemporaneous with deposition of the younger parts is provided by the presence of recycled grains of prehnite and pumpellyite in turbidites. In the Northern Belt, the cleavage is axial-planar to folds. In contrast, in the Central Belt the obliquity between cleavage and fold hinges indicates a deformation regime dominated by sinistral transpression (e.g. Stringer \& Treagus, 1980; Anderson, 1987; Holdsworth et al., 2002). The change from early coaxial deformation in the Northern Belt to sinistral tranpression in the central Belt may reflect a change in the angle of subduction relative to the continental margin. A final stage of deformation resulted in low-angle, northwestdirected thrusts.

1138 The overall sedimentological and tectonic features of the Southern Uplands-Longford Down terrane compare closely with modern examples of acccretionary prisms such as the Oaxaca prism off Mexico (Leggett, 1987). An alternative interpretation, that the Northern Belt rocks were deposited in a back-arc basin, hinged critically on horizons of southeast-derived volcaniclastic detritus that were thought to have been derived from an active volcanic arc (Stone et al., 1987). Phillips et al. (2003) found no detrital zircons in these rocks that yielded $\mathrm{U}-\mathrm{Pb}$ ages younger than the Neoproterozoic, and inferred a provenance from a peri-Gondwanan terrane to the south. The larger $\mathrm{U}-\mathrm{Pb}$ detrital zircon dataset of Waldron et al. (2008) demonstrates the Neoproterozoic zircons are likely derived from igneous rocks associated with Iapetan rifting of the Laurentian margin with only a minor population that overlaps the Caradocian depositional age of the host sedimentary rocks. These data are difficult to reconcile with extensional continental-margin and back-arc models. With the key objection to an accretionary prism model removed they instead support an active continental-margin subductionaccretion model. Clay mineral assemblages and white mica compositions within the sedimentary rocks of the Southern Uplands-Longford Down terrane are indicative of deposition in a low heat-flow tectonic setting, consistent with an accretionary prism (Stone \& Merriman, 2004).

1157 Summary of the temporal evolution of the Grampian Orogeny: arc-continent collision along the Laurentian margin

1159 Lambert and McKerrow (1976) recognized that the Dalradian sequences of the Scottish 1160 Highlands had undergone polyphase deformation and metamorphism during the 1161 Ordovician. This phase of orogenic activity clearly predated the post-Silurian Acadian 1162 deformation which marked the final stages of Caledonian tectonism in Britain and 1163 Ireland, and they coined the term "Grampian Orogeny" to distinguish this Ordovician 1164 tectonic event. The Grampian Orogeny is now widely regarded as having resulted from 1165 the collision of Laurentia with an oceanic arc during the Arenig (Dewey and Shackleton, 
1166 1984). It is broadly equivalent to the Taconic Orogeny of the New England Appalachians

1167 and the Humberian Orogeny of the western Newfoundland Appalachians (Dewey and 1168 Mange, 1999; van Staal et al., 1998; Dewey and Shackleton, 1984).

1169 Closure of the Iapetus Ocean is thought to have commenced with the subduction of 1170 Iapetan crust of the Laurentian margin under a chain of primitive, continent-facing 1171 oceanic arcs during the Late Cambrian / Tremadocian (c. 500 - 480 Ma; Dewey \& 1172 Mange, 1999; Van Staal et al., 1998; Fig. 16). It has been suggested that these arcs may 1173 have originally nucleated on oceanic transform faults (Karson \& Dewey, 1978) during

1174 the Middle Cambrian (Dewey \& Mange 1999). In SW Scotland and western Ireland the 1175 formation of oceanic crust and high-grade metamorphism associated with ophiolite 1176 obduction in the Highland Border and Deerpark (=Clew Bay) ophiolites is dated at c. 1177500 - 490 Ma (Chew et al., 2010) and a subduction-related magmatic arc founded on 1178 ophiolitic basement was active in both regions by ca. $490 \mathrm{Ma}$ (Chew et al., 2007, 2010).

1180 With the onset of subduction, these mafic, infant Grampian - Taconic arcs evolved into 1181 Early Ordovician intermediate arcs with associated suprasubduction ophiolites (Dewey 1182 \& Mange 1999). Collision of the arc and ophiolite with the Laurentian margin is well 1183 constrained in the Baie Verte Oceanic Tract of the Notre Dame Subzone in 1184 Newfoundland. Upper Cambrian - Middle Tremadoc suprasubduction ophiolites and 1185 juvenile volcanic-plutonic complexes were obducted onto the Laurentian margin, which 1186 is thought (based on seismic reflection data) to structurally underlie the entire Notre 1187 Dame Subzone (Keen et al., 1986). The arc / ophiolite allochthon and the underlying 1188 ophiolitic mélange are cut by arc-related plutons as old as Early Arenig (Van Staal et al., 1189 1998) and the isotope geochemistry of these tonalitic - granitic stitching plutons 1190 suggests they have ascended through continental crust (Whalen et al., 1997). Hence, if 1191 the Baie Verte Oceanic Tract does indeed structurally overlie Laurentian crust, then slab 1192 break off and a subsequent polarity reversal is implied.

1193 In western Ireland, the detrital record of the South Mayo Trough (the Grampian fore-arc 1194 basin) implies the progressive unroofing of an ophiolite complex in the Arenig followed 1195 by the exhumation of the Grampian metamorphic belt during the middle Ordovician 1196 (Fig. 13, Wrafter \& Graham, 1989, Dewey \& Mange, 1999). The chemistry of the arc 1197 volcanic rocks (Lough Nafoeey arc) changes from a primitive boninitic and tholeiitic 1198 chemistry to higher silica, higher-K compositions with increasing LREE enrichment and 1199 lower $\varepsilon N d(t)$ values (Fig. 12, Clift and Ryan, 1994; Ryan et al., 1980), indicating 1200 progessive assimilation of old continental material associated with the subduction of 1201 continental margin sediments. The change in subduction polarity inferred in the 1202 Newfoundland sector of the orogen has also been suggested to have occurred in Ireland 
1203 and Scotland with the voluminous basic intrusions in the Dalradian of Connemara and 1204 NE Scotland having been interpreted as the roots of a volcanic arc (Yardley et al., 1982; 1205 Yardley \& Senior, 1982), generated by subduction underneath the Laurentian margin.

1206 Several models for the Grampian and Taconic orogens (e.g. Dewey \& Mange, 1999; Van 1207 Staal et al., 1998; Dewey \& Shackleton, 1984) attribute the bulk of the deformation and 1208 metamorphism to the obduction of the forearc ophiolite onto the Laurentian margin. In 1209 such models, SE-directed subduction is accompanied by obduction of a thick arc1210 ophiolite nappe onto the Laurentian margin which stacked the Dalradian nappe pile and 1211 accreted the arc to the margin with the collisional suture represented by the Baie Verte 1212 - Clew Bay - Highland Border Line, a diverse package of accreted material 'swept up' by 1213 the oceanic arc (Figs. 3, 14, 16; Dewey \& Mange, 1999). In contrast, Tanner (this

1214 volume) proposes a model for the Grampian Orgeny in Scotland based on the regional 1215 kinematics of the polyphase-deformed Dalradian rocks, including a top-to-the-SE shear 1216 sense for D1 structures on the upper limb of the Tay nappe. The Tanner model thus 1217 infers an early stage of NW-directed subduction accompanied by obduction of an 1218 ophiolite onto the Laurentian margin. There is no difference in the timing of Barrovian 1219 metamorphism of the Dalradian Supergroup between the Scottish and Irish sectors of 1220 the orogenic belt, with abundant geochronological data demonstrating that polyphase 1221 deformation and regional metamorphism up to upper-amphibolite-facies conditions 1222 occurred over a short time period ( 10 m.y.) during the Grampian orogeny between c. 1223475 and 465 Ma (Dewey, 2005). Subsequent subduction of the Iapetus Ocean under the 1224 Laurentian margin is believed to continue into the Silurian (Van Staal et al., 1998), with 1225 large amounts of material being shed off the uplifting orogen into thick accretionary 1226 prisms such as the Southern Upland and Longford - Down belts (Hutchison \& Oliver, 1227 1998).

1228

1229 Summary of the Silurian orogenic events resulting from the collision of Laurentia, 1230 Baltica and Avalonia and the closure of the Iapetus Ocean

1231 Silurian collision between Baltica and Laurentia: the Scandian orogeny in the Northern 1232 Highlands Terrane

1233 The Northern Highlands Terrane of Scotland (Figs 2, 4) records evidence for significant 1234 Silurian regional deformation and metamorphism that is attributed to the collision of 1235 the Laurentian margin of Scotland and East Greenland with Baltica (the Scandian 1236 Orogeny), resulting in widespread reworking of the Moine Supergroup. Regional-scale, 1237 NW-directed 'D2' ductile thrusting that culminated in development of the Moine Thrust 1238 Zone was accompanied by widespread folding and fabric development under 1239 amphibolite- to greenschist-facies conditions (e.g. Strachan \& Holdsworth, 1988; 
1240 Holdsworth, 1989; Holdsworth et al., 2001, 2007; Kinny et al., 2003a; Kocks et al., 2006;

1241 Krabbendam et al., 2011). Field-based structural models have long-viewed the Sgurr

1242 Beag, Naver and Moine thrusts as part of the same kinematically linked system of 1243 foreland-propagating deformation (Barr et al., 1986).

1244 Regional metamorphic grade during the Scandian event varies from low to mid1245 amphibolite facies in the central Moine outcrop to greenschist-facies in the vicinity of 1246 the Moine Thrust Zone (Johnson \& Strachan, 2006). In north Sutherland, temperatures 1247 of $>500^{\circ} \mathrm{C}$ are indicated by 1 ) a U-Pb SIMS monazite age of $431 \pm 10$ Ma obtained from 1248 the Naver nappe (Kinny et al., 1999); 2) kyanite, staurolite and the euhedral rims of 1249 recystallised and zoned garnets overgrowing the main Scandian schistosity 1250 (Holdsworth et al., 2001) and 3) a Scandian lineation defined by aligned hornblende 1251 needles and recrystallised feldspar augen. A partial clockwise pressure-temperature 1252 path for the Scandian event here indicates metamorphic conditions of $640-660^{\circ} \mathrm{C}$ and 5 1253 kbar (Friend et al. 2000). Rb-Sr and ${ }^{40} \mathrm{Ar} /{ }^{39} \mathrm{Ar}$ mineral ages obtained in an east-west 1254 traverse across the Moine outcrop of Sutherland generally range between c. 440 Ma and 1255 c. $410 \mathrm{Ma}$ (Dallmeyer et al., 2001) confirming widespread reheating during the Scandian 1256 event, even in the eastern Moines where the structural imprint is restricted.

1257 Widespread Scandian upright folding in the central part of the Moine outcrop resulted 1258 in the formation of the Northern Highland Steep Belt (Clifford, 1957; Powell et al., 1981; 1259 Roberts \& Harris, 1983). In the area south of Fannich, the Moine rocks between the 1260 'Loch Quoich Line' and the western seaboard are generally steeply-dipping, although 1261 some areas in Knoydart and Ardnamurchan escaped the pervasive folding. A large part 1262 of the steep belt is occupied by the Glenfinnan Group. N-S to NNE-trending tight folds 1263 are developed on all scales, typically with highly curvilinear hinges and accompanied by 1264 crenulation cleavage. The stability of garnet, biotite and hornblende within crenulations 1265 suggests that deformation occurred at temperatures $>500^{\circ} \mathrm{C}$. There is clear evidence in 1266 the Fannich and Lochailort areas that the Sgurr Beag Thrust is folded by upright folds 1267 (Powell et al., 1981; Kelley \& Powell, 1985; Krabbendam et al., 2011). The upright folds 1268 may themselves detach on the structurally underlying Moine Thrust. A U-Pb TIMS 1269 zircon age of $426 \pm 3$ Ma obtained from the Glen Scaddle Metagabbro which predates 1270 upright folding indicates that deformation occurred during the final stages of the 1271 Scandian event (Strachan \& Evans, 2008).

1272 The Scandian orogenic event culminated in the development of the Moine Thrust Zone 1273 which represents the western margin of the Scottish Caledonides (Figs 2, 3, 4). Within 1274 the thrust zone, Lewisian basement gneisses, and Torridonian and Cambrian1275 Ordovician sedimentary rocks are complexly thrust-faulted and folded (e.g. Peach et al., 1276 1907; Elliott \& Johnson, 1980; McClay \& Coward, 1981). The Cambrian-Ordovician 1277 rocks record peak metamorphic temperatures of only c. $275^{\circ} \mathrm{C}$ in the upper anchizone 
1278 (Johnson et al., 1985), and so the thrust zone developed at much higher crustal levels

1279 than the internal ductile thrusts described above. Balanced cross-sections constructed

1280 from within the thrust zone itself, as well as the association of the Moine Thrust sensu

1281 stricto with a thick belt of mylonites, suggest substantial displacements (Elliott \&

1282 Johnson, 1980; Butler \& Coward, 1984). A total minimum displacement for the Moine

1283 Thrust Zone of c. $100 \mathrm{~km}$ is generally accepted. U-Pb TIMS zircon ages obtained from a

1284 range of syn- to post-thrusting intrusions in the Assynt area constrain thrusting to have

1285 occurred at c. 430 Ma (Fig. 3, Goodenough et al., 2011). This is consistent with Rb-Sr and

$1286 \mathrm{~K}-\mathrm{Ar}$ ages of c. 435-430 Ma obtained from recrystallised mica within mylonitic Moine

1287 rocks just above the Moine Thrust (Johnson et al., 1985; Kelley, 1988; Freeman et al., 1288 1998).

\section{Silurian collision between Avalonia and Laurentia}

1290 In contrast to the 'hard' Laurentia-Baltica collision detailed above, reference has already 1291 been made to the highly oblique and relatively 'soft' nature of the collision between 1292 Avalonia and Laurentia. NW-directed contractional structures such as folds, cleavage 1293 development and thrusts that developed under generally low-grade metamorphic 1294 conditions may have in part developed in conjunction with significant strike-slip 1295 displacements along the Highland Boundary and Southern Uplands faults.

1296 The initial collision of Avalonia and Laurentia occurred after the Wenlock and it was 1297 probably at this stage that the Southern Uplands accretionary prism was overthrust 1298 onto the southern margin of the Midland Valley Terrane. A 'lost' metamorphic-igneous 1299 source for the southerly-derived Silurian conglomerates of the Midland Valley is 1300 inferred to be located at depth beneath the accretionary prism (Bluck 1984). Deep 1301 seismic reflection profiling suggests that the accretionary prism is underlain by a 1302 southward-dipping reflector which is interpreted as a north-directed thrust formed 1303 during Avalonia-Laurentia collision (Hall et al. 1984). Late, low-angle thrusts (e.g. 1304 Needham 1993) within the Northern and Central belts of the accretionary prism in 1305 Scotland probably formed at this time. The Mid-Ordovician to Silurian rocks of the 1306 Girvan inlier were deformed by NW-vergent folds and thrusts, accompanied by very 1307 low-grade metamorphism. In contrast, the Silurian rocks elsewhere in the Midland 1308 Valley terrane in Scotland were only weakly deformed, testifying to the generally 'soft' 1309 nature of the collision.

1310 Structures developed within the Ordovician and Silurian rocks of the South Mayo 1311 Trough are consistent with the highly oblique nature of the collision indicated by 1312 palaeomagnetic studies. Widespread folding and cleavage development is known to 1313 have occurred after the Wenlock but prior to the deposition of unconformably overlying 1314 Lower Devonian strata. The upright Croagh Patrick Syncline is associated with three 
1315 sets of overprinting folds and cleavages that developed during sinistral transpression

1316 (Hutton \& Dewey, 1986). Metamorphic grade was sub-greenschist facies.

\section{Current controversies in the Laurentian Caledonides of Scotland and Ireland}

1318 Despite being one of the most intensively studies orogenic belts in the world, there 1319 remain various outstanding issues in our understanding of the Laurentian Caledonides 1320 of Scotland and Ireland. These problems stem at least in part from a lack of 1321 chronological control and the difficulties in recognizing orogenic unconformities in 1322 polyphase-deformed rocks (Tanner and Bluck, 1999). Some of the outstanding issues 1323 are discussed below.

1324 The relationship between Neoproterozoic orogenesis and the Grampian/Caledonian 1325 overprint

1326 Geochronological studies indicate that a complex series of early to mid-Neoproterozoic 1327 orogenic events affected the Moine Supergroup and correlative units. The earliest event 1328 at c. $930 \mathrm{Ma}$ is recorded in the Westing Group in Shetland (Fig. 3; Cutts et al. 2009), and 1329 a range of metamorphic events in the 840-725 Ma interval have been proposed for the 1330 Moine Supergroup and Badenoch Group (Fig. 3; Noble et al. 1996; Rogers et al. 1998; 1331 Vance et al. 1998; Highton et al. 1999; Tanner \& Evans 2003; Cutts et al. 2010). These 1332 successions were probably located near to the periphery of Rodinia during the 1333 Neoproterozoic (Li et al. 2008) and it seems likely that these metamorphic events 1334 resulted from accretionary processes (Cawood et al. 2010; Kirkland et al. 2011).

1335 The relative intensities of Neoproterozoic versus Lower Palaeozoic orogenic events has 1336 been much debated at different localities. The early $\left(D_{1}\right)$ nappe-scale folds within the 1337 Morar Group between Morar and Glenelg (Ramsay, 1958; Powell, 1974) seem likely to 1338 be Neoproterozoic in age, although this is the only area where such structures have 1339 been yet identified. Tanner \& Evans (2003) further argued that the Sgurr Beag Thrust 1340 between Lochailort and Kinlochourn is Neoproterozoic in age, although it is regarded as 1341 essentially a Caledonian structure in the Fannich area to the north (Kelley \& Powell 1342 1985; Krabbendam et al. 2011). East of Fannich, intrusion of the Carn Chuinneag 1343 Granite at 594 Ma (Oliver et al. 2008) was thought to have post-dated $\mathrm{D}_{1}$ deformation 1344 and metamorphism (Wilson \& Shepherd 1979), although this was challenged by Soper 1345 \& Dalziel (1997) who concluded that intrusion occurred pre- $\mathrm{D}_{1}$. Further 1346 geochronological and structural studies are necessary in all these areas. In general, it 1347 seems to be the case that ductile reworking during the Caledonian orogeny effected 1348 considerable modification of Neoproterozoic structures and metamorphic assemblages 1349 in most if not all areas. The Neoproterozoic events are now represented by the oldest 1350 (and often composite) foliations, isoclinal folds and porphyroblasts with few examples 1351 of tectonic windows of low Caledonian strain. 
1352 The duration of Dalradian Supergroup sedimentation and the presence and significance of 1353 intra-Dalradian unconformities

1354 The stratigraphically lowest part of the Dalradian Supergroup that is constrained by 1355 reliable geochronological data is the c. $600 \mathrm{Ma}$ (U-Pb zircon; Halliday et al., 1989; 1356 Dempster et al. 2002) Tayvallich Volcanic Group which marks the top of the Argyll 1357 Group. Much debate has centred around the duration of sedimentation represented by 1358 the underlying Argyll, Appin and (basal) Grampian groups. The Badenoch Group that 1359 forms part of the basement to the Dalradian Supergroup in Scotland was affected by 1360 high-grade metamorphism at c. 840 Ma (Highton et al., 1999) and this must represent a 1361 lower limit for Dalradian sedimentation. However, whether the Dalradian basin was 1362 initiated at, say, c. $800 \mathrm{Ma}$, or substantially later, remains controversial. Debate centres 1363 around two issues. The first concerns the field relations of deformed pegmatites in the 1364 Grampian Highlands that have yielded U-Pb monazite ages of c. $800 \mathrm{Ma}$ (Noble et al., 1365 1996). One view holds that these pegmatites intrude the basal Grampian Group 1366 (Piasecki \& van Breemen 1983), in which case Dalradian sedimentation must have 1367 commenced prior to $800 \mathrm{Ma}$ (Noble et al., 1996). The alternative view is that these 1368 pegmatites only intrude the Badenoch Group (Smith et al., 1999), in which case they 1369 place no constraint on the age of the Grampian Group. The second issue concerns the 1370 age of the Port Askaig Tillite at the base of the Argyll Group. The general consensus has 1371 been that this correlates with the global c. 720 Ma Sturtian glacial event (Prave et al., 1372 2009). However, a rather younger age is implied by the data of Rooney et al. (2011) who 1373 have presented a Re-Os age of $660 \pm 10$ Ma for deposition of the Ballachulish Slate in the 1374 middle of the underlying Appin Group. They correlate the Port Askaig Tillite with the $1375 \sim 650$ Ma end-Sturtian glacial events in Australia, and thus Dalradian sedimentation 1376 may have been initiated as late as $700 \mathrm{Ma}$.

1377 Irrespective of whether or not Dalradian sedimentation was initiated at $>800$ Ma or 700 1378 Ma, a related issue concerns the continuity or otherwise of the succession. The general 1379 consensus has been that it is broadly continuous and has only been affected by one 1380 orogenic event (the Caledonian sensu lato). However, Hutton \& Alsop (2004) proposed 1381 that the Dalradian succession contains a fundamental orogenic unconformity located 1382 within the Argyll Group. They infer that the intra-Argyll Group Stralinchy Conglomerate 1383 in Donegal, NW Ireland, contains clasts that closely resemble the local Dalradian rocks 1384 and that these clasts include pre-incorporation deformation fabrics formed at low-mid 1385 greenschist facies grade. Hutton \& Alsop (2004) attributed these fabrics to a 1386 Neoproterozoic orogenic event that affected the lower part of the Dalradian succession. 1387 If Dalradian sedimentation commenced at c. $800 \mathrm{Ma}$, then such an event might, for 1388 example, correlate with the youngest of the Knoydartian events identified within the 1389 Moine Supergroup at c. 735-725 Ma (Tanner \& Evans, 2003; Cutts et al., 2010). 
1390 Reinterpretation of the Stralinchy Conglomerate as a glacial tillite by McCay et al. 1391 (2006) does not change the nature of the debate if the clasts were derived from the local 1392 Dalradian. This was disputed by Tanner (2005) who argued that the clasts are more 1393 likely to be extrabasinal, and also that there was no evidence of an orogenic 1394 unconformity at the equivalent lithostratigraphic level within the Scottish Dalradian 1395 succession.

1396 When did Iapetus open in this segment of the Caledonian - Appalachian belt?

1397 There is abundant evidence that the final rifting event to affect Laurentia initiated 1398 during the late Neoproterozoic. Such evidence includes the stratigraphic rift-to-drift 1399 transition in Laurentian margin sequences at the Precambrian-Cambrian boundary (e.g. 1400 Bond et al., 1984, Williams \& Hiscott, 1987), and the voluminous rift-related magmatism 1401 along the Laurentian margin which lasted from 620 Ma to $550 \mathrm{Ma}$ (e.g. Kamo et al., 1402 1989; Bingen et al. 1998; Cawood et al., 2001, Kinny et al., 2003b). However the precise 1403 timing of break-up is more difficult to assess, mainly because of the poor available 1404 constraints on the timing of the rift-drift transition along many sectors of the 1405 Laurentian margin. Van Staal et al. (in review) consider that although the sense of 1406 diachoneity is poorly constrained, available data suggest that rifting progressed from 1407 northeast to southwest in present coordinates, being the oldest in Baltica (Bingen et al., 1408 1998; Svenningsen, 2001) and becoming younger in Scotland (e.g. Leslie et al., 2008) 1409 and the Appalachians (van Staal et al., 1998; Cawood et al., 2001).

1410 The timing of rifting is probably best constrained on the Appalachian margin. Here the 1411 last major magmatic pulse between 615 and $570 \mathrm{Ma}$ is generally thought to be related 1412 to the opening of the Iapetus Ocean (Kamo et al., 1989; Cawood et al., 2001), consistent 1413 with paleomagnetic evidence that suggests that eastern Laurentia had separated from 1414 its conjugate margin(s) during the Late Ediacaran (McCausland et al., 2007). However, 1415 thermal subsidence analysis suggests the rift-drift event appears to have taken place 1416 during the late Early Cambrian, at least 30-40 my later, along the length of the 1417 Appalachian margin (Bond et al., 1984; Williams and Hiscott, 1987; Cawood et al., 2001; 1418 Waldron and van Staal, 2001), which is supported by a small, latest Ediacaran rift1419 related pulse of predominantly MORB magmatism between 565 and $550 \mathrm{Ma}$ along the 1420 Appalachian Humber margin (Cawood et al., 2001, Hodych and Cox, 2007). To explain 1421 this apparent paradox, Cawood et al. (2001) and Waldron and van Staal (2001) invoked 1422 a multistage rift history that involved an initial separation of Laurentia from the west 1423 Gondwana cratons at ca. $570 \mathrm{Ma}$, followed by rifting of a further block or blocks from 1424 Laurentia (e.g. the Dashwoods ribbon microcontinent) at ca. 540-535 Ma into an 1425 already open Iapetus Ocean to establish the main passive-margin sequence in eastern 1426 Laurentia. 
1427 On the Scottish-Irish sector of the Laurentian margin, basic volcanic activity in the

1428 Dalradian Supergroup occurred throughout the Argyll Group and the lower part of the 1429 Southern Highland Group, reaching its greatest development in the Easdale and 1430 Tayvallich subgroups of the Argyll Group (Fettes et al., 2011). Absolute age constraints 1431 on the timing of volcanic activity are poor, with the only reliable geochronology being 1432 the U-Pb zircon dates of $595 \pm 4 \mathrm{Ma}$ on a keratophyre intrusion (Halliday et al., 1989) 1433 and of $601 \pm 4$ Ma on a felsic tuff (Dempster et al., 2002) from within the Tayvallich 1434 Volcanic Formation of the upper Argyll Group. Fettes et al. (2011) provided age 1435 estimates on the age of volcanic activity within the Dalradian Supergroup based on 1436 lithostratigraphic and chemostratigraphic correlation arguments that are summarised 1437 as follows. The first, minor, volcanic episode occurred at the base of the Argyll Group 1438 (Islay Subgroup) in NE Scotland (Stephenson and Gould, 1995; Chew et al., 2010). The 1439 age is uncertain, with a maximum age of $720 \mathrm{Ma}$ and a minimum age of $640 \mathrm{Ma}$ 1440 depending on whether the main Dalradian glacial horizon (the Port Askaig Tillite and its 1441 correlative horizons) is equivalent to the Sturtian or Marinoan global glacial. This phase 1442 of volcanism was followed by a period of relative quiescence. The major phase of 1443 activity occurred during Easdale Subgroup times (at around $\sim 630$ to $620 \mathrm{Ma}$ ) 1444 associated with increased crustal extension. The final phase took place during 1445 Tayvallich Subgroup - basal Southern Highland Group times (between $\sim 610$ and 590 $1446 \mathrm{Ma}$ ), with all activity finished by $\sim 570 \mathrm{Ma}$. An extensive suite of rift-related silicic 1447 intrusions, the Vuirich suite (along with temporal equivalents in the Northern 1448 Highlands Terrane such as the Carn Chuinneag granite), is believed to have been 1449 emplaced at 590 Ma (Fig. 3; Rogers et al., 1989) suggesting a major episode of bimodal 1450 magmatism at that time (Macdonald \& Fettes, 2006).

1451 Associated with the Easdale Subgroup volcanism is a stratigraphic horizon with 1452 abundant serpentinite olistoliths embedded in a graphitic pelite matrix (Kennedy, 1453 1980). The serpentinite bodies are also associated with deep-marine psammitic wackes 1454 and graphitic pelites. A discontinuous horizon of serpentinite bodies has also been 1455 documented in Easdale Subgroup rocks of central and NE Scotland (Garson \& Plant, 1456 1973). These serpentinite bodies in Ireland and Scotland have been interpreted as 1457 protrusions of serpentinized mantle onto the seafloor that were generated in Easdale 1458 Subgroup times during a phase of major crustal extension leading to the formation of an 1459 ocean-continent transition zone (Chew, 2001). Easdale Subgroup volcanism has been 1460 suggested above to have occurred at around 630 to $620 \mathrm{Ma}$ (Fettes et al., 2011), and 1461 therefore the onset of hyperextension and break-up is inferred to have started at this 1462 time. This is substantially older than the timing of hyperextension and break-up on the 1463 Appalachian Humber margin. The Birchy Complex of Newfoundland is regarded to 1464 represent a fossil ocean-continent transition zone (van Staal et al., in press), and 1465 although it closely resembles and has been correlated with the Easdale Subgroup in 
1466 western Ireland (Winchester et al., 1992), it is substantially younger at c. 558 Ma (van

1467 Staal et al., in press).

1468 The supra-subduction ophiolite vs sub-continental lithospheric mantle debate in the 1469 Highland Border

1470 The recent reinterpretation of the Highland Border Complex (Tanner and Sutherland, 1471 2007) suggests that the majority of the sequence is in stratigraphic continuity with the 1472 Dalradian Supergroup, with the exception of a series of poorly exposed fault-bound 1473 slivers of ophiolitic rocks within the fault zone, known as the Highland Border Ophiolite 1474 (Tanner and Sutherland, 2007). The affinity of this suite of ophiolitic rocks has also been 1475 called into question by Tanner, who suggests that they represent exhumed 1476 serpentinised sub-continental lithospheric mantle, similar to the Ligurian-type 1477 ophiolites of northern Italy.

1478 The principal findings of Highland Workshop 2008 field excursion to the Highland 1479 Border that addressed these issues have been synthesized by Leslie (2009) and 1480 Henderson et al. (2009) and are summarized here. Fragmental ophicarbonate-rock is 1481 widespread from Aberfoyle to Bute along the Highland Boundary Fault (Fig. 10) and 1482 exhibits a striking resemblance to material recovered from modern Iberia-type ocean1483 continent transitions. Additionally the more tectonised examples of HBO serpentinites 1484 and ophicarbonate-rocks are also remarkably similar to examples from Ligurian-type 1485 ophiolites. The field observations broadly support a model in which the sheared and 1486 fragmental ophicarbonate-rocks and associated sediments of the HBO originated in a 1487 stretching ocean-continent transition setting, now preserved as a fragment of Ligurian1488 type ophiolite on the southeastern margin of the Grampian orogenic belt. The 1489 discontinuous horizon of serpentinite bodies in the Easdale Subgroup rocks of the 1490 Dalradian Supergroup of Ireland and Scotland described by Chew (2001) are likely 1491 intimately associated with the HBO, with both units representing small slices of 1492 exhumed serpentinised sub-continental mantle that originally lay beneath an extending 1493 Dalradian basin during the opening of the Iapetus Ocean.

1494 However, not all exposures of mafic and ultramafic rocks within the HBO represent 1495 exhumed serpentinised sub-continental lithospheric mantle. For example, the 1496 geochronology and P-T work presented by Chew et al. (2010) demonstrate that the 1497 Bute Amphibolite (Fig. 10) represents a fragment of a Grampian supra-subduction zone 1498 ophiolite that was obducted at c. 490 Ma. A similar scenario is present on the Baie Verte 1499 peninsula in Newfoundland, where the Birchy Complex of Newfoundland that 1500 represents a c. 558 Ma ocean-continent transition zone (van Staal et al., in review) is in 1501 tectonic contact (along the Baie Verte - Brompton line) with the 490 Ma supra1502 subduction zone Taconic ophiolites of the Baie Verte Oceanic Tract. The fragmentary 
1503 and challenging nature of the geological record within the Highland Boundary fault zone

1504 means that the tectonic affinity of many slivers of mafic and ultramafic rock within the 1505 HBO will remain unknown.

1506 The cause of the rapid, synchronous 475 - 470 Ma Grampian orogenic peak

1507 A short, synchronous Grampian orogenic episode is inconsistent with models of 1508 conductive heat transfer in thickened crust (e.g. Dewey, 2005; Baxter et al., 2002), and 1509 these authors suggest that the ca. 470 Ma Grampian metamorphic peak may have 1510 resulted from advective heat transfer from voluminous syn-orogenic intrusive rocks in 1511 the Dalradian block, similar to the original suggestion of Barrow (1893). This 1512 hypothesis is supported by thermal modeling of Sr diffusion profiles in apatite from the

1513 Barrovian zones of NE Scotland which demonstrates that the thermal peak was brief 1514 and lasted only a few hundred thousand years, which is one or two orders of magnitude 1515 shorter than the timescales predicted by conductive relaxation of over-thickened crust 1516 (Ague and Baxter, 2007). However, although this model may be appropriate for much of 1517 NE Scotland and Connemara, most of the Dalradian block is devoid of syn-orogenic 1518 intrusive rocks, and a ca. 470 Ma orogenic peak is still detected in such rocks by 1519 geochronological studies in NW Ireland (e.g. Flowerdew et al., 2000). Vorhies \& Ague 1520 (2011) constrained the P-T evolution of the Barrovian metamorphic zones in the 1521 Grampian Terrane in Scotland along orogenic strike using a combination of 1522 thermobarometry and pseudosection analysis. They attributed regional metamorphism 1523 to be associated with the thermal relaxation of tectonically overthickened crust, but that 1524 the NE part of the Grampian terrane required additional advective heat input driven by 1525 a brief (of the order of 1 Ma or less) thermal pulse to achieve peak thermal conditions. 1526 This heat was probably supplied by synorogenic magmas (e.g. Newer Gabbros) and the 1527 associated elevated crustal heat flow. Chew et al. (2010) invoked a phase of collisional 1528 thickening beginning at c. 490 Ma based on geochronological constraints from 1529 Grampian ophiolites on the timing of obduction. As there is limited evidence for 1530 obduction of a thick slab of oceanic lithosphere, Chew et al. (2010) inferred that the 1531 deformed Laurentian margin structural pile comprised mainly Dalradian nappes. 1532 However the cause of the rapid, synchronous Grampian orogenic peak remains 1533 enigmatic.

1534 Is there evidence for a Late Ordovician accretionary event in Scotland and Ireland?

1535 The existing two stage Grampian-Scandian tectonic model for the Caledonides in the 1536 British Isles is likely to be overly simplistic. More protracted accretionary histories have 1537 been developed for other parts of the Laurentian margin such as Newfoundland and the 1538 Laurentian-derived Uppermost Allochthon in Norway. In addition to early Ordovician 1539 tectonism broadly equivalent to the Grampian event in Scotland and Ireland, these 
1540 other areas also contain evidence for accretionary events at c. 450 Ma. In Newfoundland 1541 this is represented by the 'Taconic II' collision of arcs and the Laurentian margin (van 1542 Staal et al., 2009), and in the Uppermost Allochthon of Norway by eclogite-facies 1543 metamorphism (Roberts, 2003; Corfu et al., 2002). Mention has been made above of the 1544 probable existence of a hidden crustal block located beneath an allochthonous Southern 1545 Uplands - Longford Down Terrane (Kimbell \& Stone, 1995; Stone et al., 1997). 1546 Armstrong \& Owen (2001) proposed that this is composed of two seperately accreted 1547 terranes: 'Novantia' that was accreted during the Arenig, and an outboard terrane that 1548 was accreted in the late Caradoc-Ashgill. The time of accretion corresponds to a brief 1549 hiatus in the Late Ordovician sedimentary record of the Southern Uplands accretionary 1550 prism (equivalent to one graptolite zone in Scotland with a longer break in Ireland; 1551 Barnes et al., 1995). Armstrong \& Owen (2001) equated this outboard terrane with the 1552 Popelogan - Victoria Arc - Grangegeeth Terrane of Newfoundland - Ireland (Fig. 14; 1553 van Staal et al. 1998 and references therein).

1554 To date, there has been little consideration of the potential record of Late Ordovician 1555 accretion within the 'Orthotectonic' Caledonides north of the Highland Boundary Fault. 1556 However, we note that it is broadly coincident with formation of the downward-facing 1557 Highland Downbend in western Ireland (Fig 7C; dated at c. $448 \mathrm{Ma}$, Chew et al., 2003). 1558 Furthermore, regional upright 'D3' folding of Dalradian rocks in the Central Highlands 1559 of Scotland was synchronous with the intrusion of the Glen Kyllachy granite (van 1560 Breemen \& Piasecki, 1983) that has recently yielded a U-Pb zircon age of $451 \pm 4 \mathrm{Ma}$ 1561 (Oliver et al., 2008). Shortening was only of the order of c. 5-10\% and associated with 1562 crenulation of pre-existing schistosities at greenschist-facies temperatures (Phillips et 1563 al., 1999).

1564 In the Northern Highlands Terrane, Bird et al. (2013) have identified evidence for c. 450 1565 Ma garnet-grade metamorphism and accompanying deformation in the western Moine 1566 Supergroup (Morar Group). Various pegmatites in the Glenfinnan Group that have 1567 yielded $\mathrm{Rb}-\mathrm{Sr}$ ages of c. 445-450 Ma (van Breemen et al., 1974) may have been 1568 associated with this tectonic event, as well as the Glen Dessary syenite (448 \pm 3 Ma; 1569 Goodenough et al., 2011). Bird et al. (2013) explain this tectonic event by invoking 1570 collision of an arc or a microcontinental fragment with the segment of the Laurentian 1571 margin that contained the Northern Highland Terrane (far removed at that time from 1572 the Grampian Terrane).

1573 The Caledonides of Britain and Ireland have proven to be a superb natural laboratory 1574 for the development of many key geological concepts. The abundance of detailed 1575 regional field mapping undertaken during the $20^{\text {th }}$ century has been more recently 1576 augmented by a substantial geochemical, petrological and high-precision 1577 geochronological database along with targeted field mapping studies. Certain questions 
1578 are likely to remain difficult to resolve, such as obtaining absolute age constraints on

1579 key horizons within the non-fossiliferous Neoproterzoic successions which are typically

1580 devoid of volcanic horizons amenable to producing high-precision magmatic

1581 crystallization ages. However, with the ever increasing sophistication of

1582 geochronological and petrological techniques, key research questions such as the cause

1583 of the rapid Grampian regional metamorphic peak and also the relationship between

1584 Neoproterzoic orogenesis and the Caledonian overprint (a common feature of the

1585 northeast Laurentian margin in the North Atlantic, Cawood et al., 2010) may ultimately

1586 prove possible to disentangle.

1587

1588 Acknowledgements

1589 DC would like to thank Stephen Daly, John Dewey, Michael Flowerdew, John Graham, 1590 Ben Kennedy, Barry Long, Geoff Tanner and Ken Chew for many stimulating discussions 1591 about Caledonide geology. Cees van Staal, an anonymous reviewer and volume editor

1592 Deta Gasser are thanked for comments and suggestions that significantly improved this 1593 manuscript.

1594

\section{Figure captions}

1596 Figure 1. Schematic tectonic evolution of the Caledonian orogenic cycle (the closure of 1597 the Iapetus Ocean), showing major orogenic events (e.g. the Grampian, Scandian and 1598 Acadian). Volcanic arcs are shown in green; trenches are shown in blue and indicate the 1599 polarity of subduction; collisional orogens are shown in red.

1600 a) south-directed subduction creates a volcanic arc within the Iapetus Ocean outboard 1601 of Laurentia. b) This arc collides with Laurentia causing the Grampian Orogeny, and 1602 north-directed subduction under Laurentia begins, contemporaneous with south1603 directed subduction beneath Avalonia. c) The Iapetus Ocean has nearly closed. The 1604 "head-on" collision of Baltica and Laurentia causes the Scandian Orogeny, while the 1605 highly-oblique collision between Laurentia and Avalonia causes the Acadian Orogeny.

1606 Figure 2. Geological map of the Caledonides of NW Ireland and Scotland. Inset shows a 1607 simplified geological map of Shetland and its relationship to the British and Irish 1608 Caledonides.

1609 Figure 3. Tectonostratigraphic scheme for the Laurentian Caledonides of Scotland and 1610 Ireland. Time is represented on the y-axis (note the change of scale at $600 \mathrm{Ma}$ ) and 
1611 distance from the Laurentian foreland is represented along the x-axis. Colours of the 1612 different units where possible follow those used in Figure 2.

1613 Figure 4. Geological map of the Laurentian foreland and the Northern Highlands 1614 terrane after Strachan et al. (2010) with Caledonian thrusts and $\mathrm{L}_{2}$ mineral lineations 1615 within the Moine rocks of Ross-shire and Sutherland after Law et al. (2010). Lineations 1616 are dominantly of Scandian and Grampian age west and east of the Naver/Swordly 1617 thrusts repectively. Abbreviations as follows from north to south: LE, Loch Erribol; SC, 1618 Strathy Complex; TT, Torrisdale Thrust; ST, Sole Thrust; MT, Moine Thrust; BHT, Ben 1619 Hope Thrust; SWT, Swordly Thrust; SKT, Skinsdale Thrust; AT, Achness Thrust; LB, 1620 Loch Borrolan; NT, Naver Thrust; CCG, Carn Chuinneag Granite; SBT, Sgurr Beag Thrust; 1621 G, Glenelg; FAGG, Fort Augustus Granite Gniess; AGG, Ardgour Granite Gneiss. The 1622 Naver and Skinsdale nappes lie above the Naver and Skinsdale thrusts respectively.

1623 Figure 5. Cross-sections across the Morar Group in Sutherland (after Alsop et al., 2010) 1624 and the Fannich area (after Krabbendam et al., 2011).

1625 Figure 6. Geological map of the pre-Devonian rocks of western Ireland after Chew et al. 1626 (2007).

1627 Figure 7. Schematic structural sections though (a) the Grampian Belt in Scotland, (b) 1628 NW Mayo and (c) Donegal. Adapted from Strachan (2000) and Chew (2003). The profile 1629 traces are shown on Figs 2, 4 and 5.

1630 Figure 8. Geological map of the Tyrone Igneous Complex and the Tyrone Central Inlier 1631 (Hutton et al., 1985).

1632 Figure 9. Geological map of the Slishwood Division after Flowerdew and Daly (2005). 1633 Pressure - temperature estimates and Sm-Nd garnet ages for the pre-Grampian 1634 granulite facies event in the Slishwood Division from Flowerdew and Daly (2005) and 1635 Sanders et al. (1987) are also illustrated.

1636 Figure 10. Geology and the revised stratigraphic model of the Highland Border region 1637 after Tanner and Sutherland (2007).

1638 Figure 11. Simplified map of the Ballantrae complex. Modified from Sawaki et al. 1639 (2010) after Smellie and Stone (2001) and Kimbell and Stone (1995).

1640 Figure 12. Temporal evolution of some geochemical parameters of the South Mayo 1641 volcanic arc and its proposed link with orogenic evolution (Draut et al., 2004).

1642 Figure 13. Temporal evolution of detrital heavy mineral assemblages of sandstones 1643 from the northern limb of the South Mayo Trough. The percentage of each component 1644 (e.g. chrome spinel or metamorphic detritus) is illustrated in the histogram. Also shown 
1645 is the whole rock geochemistry (Wrafter and Graham, 1989) and a U-Pb zircon age from 1646 an ignimbrite (Dewey and Mange, 1999).

1647 Figure 14. Simplified tectonic reconstruction illustrating the relative position of 1648 terranes up to and during the Grampian Orogeny (after Armstrong and Owen, 2001). $1649 \mathrm{NH}=$ Northern Highland Terrane; GT = Grampian Terrane; LN-MV = Lough Nafooey 1650 Midland Valley Arc; Nov. = Novantia; PVA = Popelogan - Victoria Arc - Grangegeeth 1651 Terrane.

1652 Figure 15. The accretionary prism model for the formation of the Longford-Down 1653 Southern Uplands Terrane during Late Ordovician to Early Silurian times after 1654 Anderson (2004).

1655 Figure 16. (a) Schematic model of the tectonic evolution of the Laurentian margin in 1656 Scotland and Ireland at (a) $490 \mathrm{Ma}$ and (b) $480 \mathrm{Ma}$. HBC = Highland Border Complex, $1657 \mathrm{CBC}=$ Clew Bay Complex, HBF $=$ Highland Boundary Fault, FHCBL $=$ Fair Head - Clew 1658 Bay Line, modified after Chew et al. (2010).

1659

\section{References}

1661 AGUE, J. J. \& BAXTER, E. F. 2007. Brief thermal pulses during mountain building recorded 1662 by $\mathrm{Sr}$ diffusion in apatite and multicomponent diffusion in garnet. Earth and Planetary 1663 Science Letters, 261, 500-516.

1664

1665 AlSOP, G. I. 1991. Gravitational collapse and extension along a mid-crustal detachment: 1666 the Lough Derg Slide, northwest Ireland. Geological Magazine, 128, 345-354.

1668 AlsoP, G. I. 1996. Tectonic analysis of progressive secondary deformation in the hinge of 1669 a major Caledonian fold nappe, north-western Ireland. Geological Journal, 31, 217-233.

Alsop, G. I., Cheer, D. A., Strachan, R. A., Krabbendam, M., Kinny, P. D., Holdsworth, R. E. \& 1672 LesLIE, A. G. 2010. Progressive fold and fabric evolution associated with regional strain 1673 gradients: a case study from across a Scandian ductile thrust nappe, Scottish 1674 Caledonides. In: LaW, R., Butler, R. W. H., Holdsworth, R. E., Krabbendam, M. \& Strachan, 1675 R. A. (eds.) Continental tectonics and mountain building: the legacy of Peach and Horne. 1676 Geological Society, London, Special Publications, 335, 255-274.

1678 Alsop, G. I. \& HutTon, D. H. W. 1993. Major southeast-directed Caledonian thrusting and 1679 folding in the Dalradian rocks of mid-Ulster: implications for Caledonian tectonics and 1680 mid-crustal shear zones. Geological Magazine, 130, 233-244. 
1682 Anderson, T. B. 1987. The Onset and Timing of Caledonian Sinistral Shear in County 1683 Down. Journal of the Geological Society, 144, 817-825.

Anderton, R. 1982. Dalradian deposition and the late Precambrian-Cambrian history of the N Atlantic region: a review of the early evolution of the Iapetus Ocean. Journal of the Geological Society, London, 139, 421-431.

1688

Anderton, R. 1985. Sedimentation and tectonics in the Scottish Dalradian. Scottish Journal of Geology, 21, 407-436.

1691

Anderson, B. 2004. Southern Uplands-Down-Longford Terrane. In: Mitchell, W. I. (ed.) Survey of Northern Ireland, Belfast, 41-60.

1695

Armstrong, H. A. \& Owen, A. W. 2001. Terrane evolution of the paratectonic Caledonides of northern Britain. Journal of the Geological Society, London, 158, 475-486.

Atherton, M. P. \& GHAni, A. A. 2002. Slab breakoff: a model for Caledonian, Late Granite syn-collisional magmatism in the orthotectonic (metamorphic) zone of Scotland and Donegal, Ireland. Lithos, 62, 65-85.

1702

1703

BADENSZKI, E., DALY, J.S. \& WhiTEHOUSE, M.J. 2011. Deep crustal metasedimentary xenoliths of the Scottish Midland Valley record Middle Devonian metamorphism of Wenlock sediments. 54 ${ }^{\text {th }}$ Irish Geological Research Meeting. Galway, Ireland, 10.

1706

1708 Uplands of southwestern Scotland - a terrane boundary. Geological Magazine, 132, 5231709529.

1711 Barr, D., Holdsworth, R. E. \& Roberts, A. M. 1986. Caledonian ductile thrusting in a 1712 Precambrian metamorphic complex - the Moine of northwestern Scotland. Geological 1713 Society of America Bulletin, 97, 754-764.

1715 BARROW, G. 1893. On an intrusion of muscovite-biotite gneiss in the southeast Highlands

1716 of Scotland and its accompanying metamorphism. Quarterly Journal of the Geological 1717 Society of London, 19, 330-358.

1718 
1719 BaXter, E. F., Ague, J. J. \& Depaolo, D. J. 2002. Prograde temperature-time evolution in the 1720 Barrovian type-locality constrained by Sm/Nd garnet ages from Glen Clova, Scotland. 1721 Journal of the Geological Society, 159, 71-82.

1722

1723 Bentley, M. R., Maltman, A. J. \& Fitches, W. R. 1988. Colonsay and Islay - a suspect terrane 1724 within the Scottish Caledonides. Geology, 16, 26-28.

1725

1726 Bingen, B., Demaiffe, D. \& van Breemen, 0. 1998. The 616 Ma Old Egersund Basaltic Dyke 1727 Swarm, SW Norway, and Late Neoproterozoic Opening of the Iapetus Ocean. Journal of 1728 Geology, 106, 565-574.

1729

1730

Bird, A. F., Thirlwall, M. F. \& Strachan, R. A. 2013. Lu-Hf and Sm-Nd dating of 1731 metamorphic garnet: evidence for multiple accretion events during the Caledonian

1732 orogeny in Scotland. Journal of the Geological Society, London, 170, 301-317.

1733

1734

BLuCK, B. 1983. Role of the Midland Valley of Scotland in the Caledonian orogeny.

1735 Transactions of the Royal Society of Edinburgh: Earth Sciences, 74, 119-136.

1736

1737

BluCK, B. 1984. Pre-Carboniferous history of the Midland Valley of Scotland.

1738 Transactions of the Royal Society of Edinburgh: Earth Sciences, 75, 275-295.

1739

1740

BLuCK, B. J. 2002. The Midland Valley terrane. In: Trewin, N. H. (ed.) Geology of Scotland, 1741 4 $4^{\text {th }}$ edition. Geological Society, London, Bath, 149-166.

1742

1743 Bluck, B. J. \& Dempster, T. J. 1991. Exotic metamorphic terranes in the Caledonides:

1744 Tectonic history of the Dalradian block, Scotland. Geology, 19, 1133-1136.

1745

1746 Bluck, B. J., Halliday, A. N., Aftalion, M. \& Macintyre, R. M. 1980. Age and origin of the 1747 Ballantrae ophiolite and its significance to the Caledonian orogeny and Ordovician time 1748 scale. Geology, 8, 492-495.

1749

1750 Bond, G. C., Nickeson, P. A. \& KominZ, M. A. 1984. of a supercontinent between 625 Ma and 1751555 Ma: New evidence and implications for continental histories. Earth and Planetary 1752 Science Letters, 70, 325-345.

1753

1754 Bonsor, H. C., Strachan, R. A., Prave, A. R. \& Krabbendam, M. 2012. Sedimentology of the 1755 early Neoproterozoic Morar Group in northern Scotland: implications for basin models 1756 and tectonic setting. Journal of the Geological Society, 169, 53-65.

1757 
1758 Brewer, T. S., Storey, C. D., Parrish, R. R., Temperley, S. \& Windley, B. F. 2003. Grenvillian

1759 age decompression of eclogites in the Glenelg-Attadale Inlier, NW Scotland. Journal of 1760 the Geological Society, 160, 565-574.

1761

1762 British Geological Survey, 1998. South Islay. Scotland Sheet 19. Solid and Drift Geology. 1763 1:50,000 Provisional Series.

1764

1765 Burns, I. M., Fowler, M. B., Strachan, R. A. \& Greenwood, P. B. 2004. Geochemistry, 1766 petrogenesis and structural setting of the meta-igneous Strathy Complex: a unique 1767 basement block within the Scottish Caledonides? Geological Magazine, 141, 209-223.

1768

1769 ButLER, R. W. H. \& CoWARD, M. P. 1984. Geological constraints, structural evolution and 1770 the deep geology of the northwest Scottish Caledonides. Tectonics, 3, 347-365.

1771

1772 Carty, J. P., Connelly, J. N., Hudson, N. F. C. \& Gale, J. F. W. 2012. Constraints on the timing 1773 of deformation, magmatism and metamorphism in the Dalradian of NE Scotland. 1774 Scottish Journal of Geology, 48, 103-117.

1775

1776 Cawood, P. A., McCausland, P. J. A. \& Dunning, G. R. 2001. Opening Iapetus: Constraints 1777 from the Laurentian margin in Newfoundland. Geological Society of America Bulletin, $1778 \mathbf{1 1 3}, 443-453$.

1779

1780 Cawood, P. A., Merle, R. E., Strachan, R. A. \& Tanner, P. W. G. 2012. Provenance of the 1781 Highland Border Complex: constraints on Laurentian margin accretion in the Scottish 1782 Caledonides. Journal of the Geological Society, 169, 575-586.

1783

1784 Cawood, P. A., Nemchin, A. A., Smith, M. \& Loewy, S. 2003. Source of the Dalradian 1785 Supergroup constrained by U-Pb dating of detrital zircon and implications for the East 1786 1787

1788 Cawood, P. A., Nemchin, A. A., Strachan, R. A., Prave, T. \& Krabbendam, M. 2007a. 1789 Sedimentary basin and detrital zircon record along East Laurentia and Baltica during 1790 assembly and breakup of Rodinia. Journal of the Geological Society, London, 167, 2571791275.

1792

1793 Cawood, P. A., Nemchin, A. A. \& Strachan, R. 2007b. Provenance record of Laurentian 1794 passive-margin strata in the northern Caledonides: Implications for paleodrainage and 1795 paleogeography. Geological Society of America Bulletin, 119, 993-1003.

1796 
1797 Cawood, P. A., Strachan, R., Cutts, K., Kinny, P. D., Hand, M. \& Pisarevsky, S. 2010.

1798 Neoproterozoic orogeny along the margin of Rodinia: Valhalla orogen, North Atlantic.

1799 Geology, 38, 99-102.

1800

1801 CHEW, D. M. 2001. Basement protrusion origin of serpentinite in the Dalradian. Irish 1802 Journal of Earth Sciences, 19, 23-35.

1803

1804 CHEw, D. M. 2003. Structural and stratigraphic relationships across the continuation of 1805 the Highland Boundary Fault in western Ireland. Geological Magazine, 140, 73-85.

1806

1807 Chew, D. M., Daly, J. S., Magna, T., Page, L. M., Kirkland, C. L., Whitehouse, M. J. \& Lam, R. 1808 2010. Timing of ophiolite obduction in the Grampian orogen. Geological Society of 1809 America Bulletin, 122, 1787-1799.

1810

1811 Chew, D. M., Daly, J. S., Page, L. M. \& Kennedy, M. J. 2003. Grampian orogenesis and the

1812 development of blueschist-facies metamorphism in western Ireland. Journal of the 1813 Geological Society, London, 160, 911-924.

1814

1815 Chew, D. M., Fallon, N., Kennelly, C., Crowley, Q. \& Pointon, M. 2010. Basic volcanism 1816 contemporaneous with the Sturtian glacial episode in NE Scotland. Earth and 1817 Environmental Science Transactions of the Royal Society of Edinburgh, 100, 399-415.

1818

1819 Chew, D. M., Flowerdew, M. J., Page, L. M., Crowley, Q. G., Daly, J. S. \& Cooper, M. 2008. The 1820 tectonothermal evolution of the Tyrone Central Inlier, Ireland: Grampian imbrication of 1821 an outboard Laurentian microcontinent? Journal of the Geological Society, London, 165, 1822 675-685.

1823

1824 Chew, D. M., Graham, J. R. \& Whitehouse, M. J. 2007. U-Pb zircon geochronology of 1825 plagiogranites from the Lough Nafooey (= Midland Valley) arc in western Ireland: 1826 constraints on the onset of the Grampian orogeny. Journal of the Geological Society, 164, 1827 747-750.

1828

1829 CLIFF, R. A. 1985. Isotopic dating in metamorphic belts. Journal of the Geological Society, 1830 London, 142, 97-110.

1831

1832 Cliff, R. A., YARdley, B. W. D. \& Bussy, F. R. 1996. U-Pb and Rb-Sr geochronology of 1833 magmatism and metamorphism in the Dalradian of Connemara, western Ireland. 1834 Journal of the Geological Society, London, 153, 109-120.

1835 
1836 Clifford, T. N. 1957. The stratigraphy and structure of part of the Kintail district of 1837 southern Ross-shire - its relationship to the Northern Highlands. Quarterly Journal of the 1838 Geological Society of London, 113, 57-92.

1839

1840 Clift, P. D., Carter, A., Draut, A. E., Van Long, H., Chew, D. M. \& Schouten, H. A. 2009. 1841 Detrital U-Pb zircon dating of lower Ordovician syn-arc-continent collision 1842 conglomerates in the Irish Caledonides. Tectonophysics, 479, 165-174.

1843

1844 ClifT, P. D. \& RYAN, P. D. 1994. Geochemical evolution of an Ordovician Island-Arc, South 1845 Mayo, Ireland. Journal of the Geological Society, 151, 329-342.

1846

1847 Cocks, L. R. M. \& FoRTEY, R. A. 1982. Faunal evidence for oceanic separations in the 1848 Palaeozoic of Britain. Journal of the Geological Society, London, 139, 465-478.

1849

1850

Cocks, L. R. M., McKerrow, W. S. \& van StaAl, C. R. 1997. The margins of Avalonia. 1851 Geological Magazine, 134, 627-636.

1852

1853

Cohen, A. S., O'Nions, R. K., Siegenthaler, R. \& Griffin, W. L. 1988. Chronology of the 1854 pressure-temperature history recorded by a granulite terrain. Contributions to 1855 Mineralogy and Petrology, 98, 303-311.

1856

1857

Cooper, M. R., Crowley, Q. G., Hollis, S. P., Noble, S. R., Roberts, S., CheW, D., Earls, G., 1858 Herrington, R. \& MErriman, R. J. 2011. Age constraints and geochemistry of the 1859 Ordovician Tyrone Igneous Complex, Northern Ireland: implications for the Grampian 1860 orogeny. Journal of the Geological Society, 168, 837-850.

1861

Cooper, M. R., Crowley, Q. G. \& Rushton, A. W. A. 2008. New age constraints for the 1863 Ordovician Tyrone Volcanic Group, Northern Ireland. Journal of the Geological Society, 1864 165, 333-339.

1865

1866 Cooper, M. R. \& Mitchell, W. I. 2004. Midland Valley Terrane. In: Mitchell, W. I. (ed.) The 1867 Geology of Northern Ireland - Our Natural Foundation (2nd edition). Geological Survey of 1868 Northern Ireland, Belfast, 25-40.

1870 Corfu, F., Ravna, E. J. K. \& Kullerud, K. 2003. A Late Ordovician U-Pb age for the Tromso 1871 Nappe eclogites, uppermost allochthon of the Scandinavian Caledonides. Contributions 1872 to Mineralogy and Petrology, 145, 502-513. 
1874 Curry, G. B., Bluck, B. J., Burton, C. J., Ingham, J. K., Siveter, D. J. \& Williams, A. 1984. Age, 1875 evolution and tectonic history of the Highland Border Complex, Scotland. Transactions 1876 of the Royal Society of Edinburgh: Earth Sciences, 75, 113-133.

1877

1878 Curry, G. B., Ingham, J. K., Bluck, B. J. \& Williams, A. 1982. The significance of a reliable 1879 Ordovician age for some Highland Border rocks in Central Scotland. Journal of the 1880 Geological Society, London, 139, 451-454.

1881

1882

Cutts, K. A., Hand, M., Kelsey, D. E., Wade, B., Strachan, R. A., Clark, C. \& Netting, A. 2009. 1883 Evidence for 930 Ma metamorphism in the Shetland Islands, Scottish Caledonides: 1884 implications for Neoproterozoic tectonics in the Laurentia-Baltica sector of Rodinia. 1885 Journal of the Geological Society, 166, 1033-1047.

1886

1887

Cutts, K. A., Kinny, P. D., Strachan, R. A., Hand, M., Kelsey, D. E., Emery, M., Friend, C. R. L. \& 1888 LESLIE, A. G. 2010. Three metamorphic events recorded in a single garnet: Integrated phase modelling, in situ LA-ICPMS and SIMS geochronology from the Moine Supergroup, NW Scotland. Journal of Metamorphic Geology, 28, 249-267.

1891

Dallmeyer, R. D., Strachan, R. A., Rogers, G., Watt, G. R. \& Friend, C. R. L. 2001. Dating 1893 deformation and cooling in the Caledonian thrust nappes of north Sutherland, Scotland: 1894 1895 insights from ${ }^{40} \mathrm{Ar} /{ }^{39} \mathrm{Ar}$ and $\mathrm{Rb}-\mathrm{Sr}$ chronology. Journal of the Geological Society, 158, 501-512.

1896

DALY, J. S. 1996. Pre-Caledonian history of the Annagh Gneiss Complex, north-western Ireland, and correlation with Laurentia-Baltica. Irish Journal of Earth Sciences, 15, 5-18.

DAlY, J. S. 2009. Precambrian. In: Holland, C. H. \& SAnders, I. S. (eds.) The Geology of 1901 Ireland, 2nd edition. Dunedin Academic Press, Edinburgh, 7-42.

1902

1903 DAlY, J. S. \& FlowerdeW, M. J. 2005. Grampian and late Grenville events recorded by 1904 mineral geochronology near a basement-cover contact in north Mayo, Ireland. Journal of 1905 the Geological Society, 162, 163-174. 1908 M. 2009. Palaeoproterozoic orthogneiss on Colonsay, SW Scotland. Abstracts 52nd 1909 Annual Irish Geological Research Meeting. Trinity College Dublin, 28. 
1911 Daly, J. S., Flowerdew, M. J. \& Whitehouse, M. J. 2004. The Slishwood Division really does

1912 have a pre-Grampian high-grade history, but is it exotic to Laurentia. Irish Journal of 1913 Earth Sciences, 22, 59.

1914

1915 DALY, J. S., MuIR, R. J. \& ClifF, R. A. 1991. A precise U-Pb zircon age for the Inishtrahull 1916 syenitic gneiss, County Donegal, Ireland. Journal of the Geological Society, London, 148, 1917 639-642.

1918

1919

DEMPSTER, T. J. 1985. Uplift patterns and orogenic evolution in the Scottish Dalradian.

1920 Journal of the Geological Society, London, 142, 111-128.

1921

1922

Dempster, T. J., Hudson, N. F. C. \& Rogers, G. 1995. Metamorphism and cooling of the NE

1923

Dalradian. Journal of the Geological Society, London, 152, 383-390.

1924

1925

Dempster, T. J., Rogers, G., Tanner, P. W. G., Bluck, B. J., Muir, R. J., Redwood, S. D., Ireland,

1926

T. E. \& PATERSON, B. A. 2002. Timing of deposition, orogenesis and glaciation within the

1927

Dalradian rocks of Scotland: constraints from U-Pb zircon ages. Journal of the Geological

1928

Society, London., 159, 83-94.

1929

1930

Dewey, J. \& Mange, M. 1999. Petrography of Ordovician and Silurian sediments in the

1931 western Ireland Caledonides: tracers of a short-lived Ordovician continent-arc collision orogeny and the evolution of the Laurentian Appalachian-Caledonian margin. In: MacNiocaill, C. \& Ryan, P. D. (eds.) Continental Tectonics. Geological Society, London, Special Publications, 164, 55-107.

1935

1936

Dewey, J. F. 2005. Orogeny can be very short. Proceedings of the National Academy of 1938 Sciences of the United States of America, 102, 15286-15293.

Dewey, J. F. \& SHACKLETon, R. M. 1984. A model for the evolution of the Grampian tract in 1941 the early Caledonides and Appalachians. Nature, 312, 115-121.

1943 the Caledonides: sinistral transpression to sinistral transtension. Journal of the 1944 Geological Society, 160, 219-229.

1945

1946 Draut, A. E. \& Clift, P. D. 2001. Geochemical evolution of arc magmatism during arc1947 continent collision, South Mayo, Ireland. Geology, 29, 543-546. 
1949 Draut, A. E., Clift, P. D., Amato, J. M., Blusztajn, J. \& Schouten, H. 2009. Arc-continent 1950 collision and the formation of continental crust: a new geochemical and isotopic record 1951 from the Ordovician Tyrone Igneous Complex, Ireland. Journal of the Geological Society, 1952 166, 485-500.

1953

1954 ELDERS, C. F. 1987. The provenance of granite boulders in conglomerates of the Northern 1955 and Central Belts of the Southern Uplands of Scotland. Journal of the Geological Society, 1956 144, 853-863.

1957

1958 ElliotT, D. \& Johnson, M. R. W. 1980. Structural evolution in the northern part of the 1959 Moine thrust belt, NW Scotland. Transactions of the Royal Society of Edinburgh: Earth 1960 Sciences, 71, 69-96.

1961

1962 Evans, J. A. \& SoPER, N. J. 1997. Discussion on metamorphism and cooling of the NE 1963 Dalradian and $\mathrm{U}-\mathrm{Pb}$ and $\mathrm{Rb}-\mathrm{Sr}$ geochronology of magmatism and metamorphism in the 1964 Dalradian of Connemara, western Ireland: Comment. Journal of the Geological Society, 1965 London, 154, 357-360.

1966

Fettes, D. J., Graham, C. M., Sassi, F. P. \& Scholari, A. 1976. The basal spacing of potassic 1968 white micas and facies series variation across the Caledonides. Scottish Journal of 1970 Geology, 12, 227-236.

Fettes, D. J., Macdonald, R., Fitton, J. G., Stephenson, D. \& Cooper, M. R. 2011. Geochemical evolution of Dalradian metavolcanic rocks: implications for the break-up of the Rodinia 1974 supercontinent. Journal of the Geological Society, 168, 1133-1146.

FLETT, J. S. 1905. On the petrographic characters of the inliers of Lewisian rocks among 1977 the Moine gneisses of the north of Scotland. Memoirs of the Geological Survey, Summary of Progress for 1905. HMSO, London, 155-167.

FLINN, D. 1956. On the deformation of the Funzie conglomerate, Fetlar, Shetland. The 1981 Journal of Geology, 480-505.

FLINN, D. 1958. The nappe structure of north-east Shetland. Quarterly Journal of the 1984 Geological Society of London, 114, 107-136. 
1988 Flinn, D. 1988. The Moine rocks of Shetland. In: Winchester, J. A. (ed.) Later Proterozoic

1989 Stratigraphy of the Northern Atlantic Regions. Blackie, Glasgow, 74-85.

1990

1991 FlinN, D. 2000. The architecture of the Shetland ophiolite. Scottish Journal of Geology, 36, 1992 123-135.

1993

1994 FLOWERDEW, M. J. 2000. The thermal history of Proterozoic rocks in the Caledonides of NW 1995 Ireland and the response of mineral dating systems to deformation. PhD thesis, University 1996 College Dublin.

1997

1998 Flowerdew, M. J., Chew, D. M., Daly, J. S. \& Millar, I. L. 2009. Hidden Archaean and 1999 Palaeoproterozoic crust in NW Ireland? Evidence from zircon Hf isotopic data from 2000 granitoid intrusions. Geological Magazine, 146, 903-916.

2001

2002 FlOWERDEW, M. J. \& DALY, J. S. 2005. Sm-Nd mineral ages and P-T constraints on the pre2003 Grampian high grade metamorphism of the Slishwood Division, north-west Ireland. 2004 Irish Journal of Earth Sciences, 23, 107-123.

2005

2006

FlowerdeW, M. J., DALY, J. S., GuISE, P. G. \& REX, D. C. 2000. Isotopic dating of overthrusting, 2007 collapse and related granitoid intrusion in the Grampian orogenic belt, northwestern 2008 Ireland. Geological Magazine, 137, 419-435.

2009

2010 FlowerdeW, M. J., DALY, J. S. \& WhitehouSE, M. J. 2005. 470 Ma granitoid magmatism 2011 associated with the Grampian Orogeny in the Slishwood Division, NW Ireland. Journal of 2012 the Geological Society, 162, 563-575.

2013

2014

2015

Freeman, S. R., Butler, R. W. H., Cliff, R. A. \& Rex, D. C. 1998. Direct dating of mylonite 2016 2017

2018 FRIEDRICH, A. M. 1998. ${ }^{40} \mathrm{Ar} /{ }^{39} \mathrm{Ar}$ and $\mathrm{U}$-Pb geochronological constraints on the thermal 2019 and tectonic evolution of the Connemara Caledonides, Western Ireland. PhD thesis, 2020 Massachusetts Institute of Technology.

2021

2022 Friedrich, A. M., Bowring, S. A., Martin, M. W. \& Hodges, K. V. 1999a. Short-lived 2023 continental magmatic arc at Connemara, western Ireland Caledonides: Implications for 2024 the age of the Grampian orogeny. Geology, 27, 27-30.

2025 
2026 Friedrich, A. M., Hodges, K. V., Bowring, S. A. \& Martin, M. W. 1999b. Geochronological

2027 constraints on the magmatic, metamorphic and thermal evolution of the Connemara

2028 Caledonides, western Ireland. Journal of the Geological Society, London, 156, 1217-1230.

2029

2030

FRIEND, C. R. L., JonES, K. A. \& BuRns, I. M. 2000. New high-pressure granulite event in the 2031 Moine Supergroup, northern Scotland: Implications for Taconic (early Caledonian) crustal evolution. Geology, 28, 543-546.

2033

2034

Friend, C. R. L., Kinny, P. D., Rogers, G., Strachan, R. A. \& Paterson, B. A. 1997. U-Pb zircon geochronological evidence for Neoproterozoic events in the Glenfinnan Group (Moine Supergroup): the formation of the Ardgour granite gneiss, north-west Scotland. 2037 2038 Contributions to Mineralogy and Petrology, 128, 101-113.

Friend, C. R. L., Strachan, R. A. \& KinnY, P. D. 2008. U-Pb zircon dating of basement inliers within the Moine Supergroup, Scottish Caledonides: implications of Archaean protolith ages. Journal of the Geological Society, 165, 807-815.

2042

2043

Friend, C. R. L., Strachan, R. A., Kinny, P. D. \& Watt, G. R. 2003. Provenance of the Moine Supergroup of NW Scotland: evidence from geochronology of detrital and inherited 2045 zircons from (meta) sedimentary rocks, granites and migmatites. Journal of the Geological Society, London, 160, 247-257.

Garson, M. S. \& Plant, J. 1973. Alpine type ultramafic rocks and episodic mountain 2050

Gass, I. G., Prichard, H. M., Neary, C. R. \& Bartholomew, I. D. 1982. The chromite of the 2052 Shetland ophiolite. A reappraisal in the light of new theory and technique. A report for

2053 the Commission of European Communities. Department of Earth Sciences, The Open 2054 University, Milton Keynes.

2055

2056 GLEndinning, N. 1988. Sedimentary structures and sequences within a late Proterozoic 2057 tidal shelf deposit: the Upper Morar Psammite Formation of northwestern Scotland. In: 2058 Winchester, J. A. (ed.) Later Proterozoic stratigraphy of the northern Atlantic regions. 2059 Springer, Glasgow, 14-31.

2060

2061 Goodenough, K. M., Millar, I., Strachan, R. A., Krabbendam, M. \& Evans, J. A. 2011. Timing 2062 of regional deformation and development of the Moine Thrust Zone in the Scottish 2063 Caledonides: constraints from the U-Pb geochronology of alkaline intrusions. Journal of 2064 the Geological Society, 168, 99-113. 
2066 Graham, J. R., LeaKe, B. E. \& RyAN, P. D. 1989. The geology of south Mayo, western Ireland. 2067 Scottish Academic Press, Edinburgh, 75.

2068

2069

Gray, J. R. \& Yardley, B. W. D. 1979. A Caledonian blueschist from the Irish Dalradian. 2070 Nature, 278, 736-737.

2071

2072 Hall, J., Brewer, J., Matthews, D. \& Warner, M. 1984. Crustal structure across the 2073 Caledonides from the WINCH seismic reflection profile: influences on the evolution of 2074 the Midland Valley of Scotland. Transactions of the Royal Society of Edinburgh: Earth 2075 Sciences, 75, 97-109.

2076

Halliday, A. N., Aftalion, M., Upton, B. G. J., Aspen, P. \& Jocelyn, J. 1984. U-Pb isotopic ages 2078 from a granulite-facies xenolith from Partan Craig in the Midland Valley of Scotland. 2079 Transactions of the Royal Society of Edinburgh: Earth Sciences, 75, 71-74.

2080

2081

Halliday, A. N., Dickin, A. P., Hunter, R. N., Davies, G. R., Dempster, T. J., Hamilton, P. J. \& 2082 UPTON, B. G. J. 1993. Formation and composition of the lower continental crust: evidence 2083 from Scottish xenolith suites. Journal of Geophysical Research, 98B, 581-607.

2084

2085

Halliday, A. N., Graham, C. M., Aftalion, M. \& Dymoke, P. 1989. Short Paper: The 2086 depositional age of the Dalradian Supergroup: $\mathrm{U}-\mathrm{Pb}$ and $\mathrm{Sm}-\mathrm{Nd}$ isotopic studies of the 2087 2088 Tayvallich Volcanics, Scotland. Journal of the Geological Society, London, 146, 3-6.

2090

Hamilton, P. J., Bluck B. J. \& Halliday, A.N. 1984. Sm-Nd ages from the Ballantrae complex, SW Scotland. Transactions of the Royal Society of Edinburgh: Earth Sciences, 75, 2091 183-187.

2092

2093 Harper, D. A. T., Williams, D. M. \& Armstrong, H. A. 1989. Stratigraphical correlations 2094 adjacent to the Highland Boundary fault in the west of Ireland. Journal of the Geological 2095 Society, London, 146, 381-384.

2096

2097

Harris, A. L., Bradbury, H. J. \& McGonigal, M. H. 1976. The evolution and transport of the 2098 Tay Nappe. Scottish Journal of Geology, 12, 103-113.

2099

2100 Harris, A. L., Haselock, P. J., Kennedy, M. J. \& Mendum, J. R. 1994. The Dalradian 2101 Supergroup in Scotland, Shetland and Ireland. In: Gibbons, W. \& Harris, A. L. (eds.) $A$ 2102 revised correlation of Precambrian rocks in the British Isles. Geological Society of London 2103 Special Reports, 22, 33-53. 
Harris, P. M., Farrar, E., Macintyre, R. M., York, D. \& Miller, J. A. 1965. Potassium-argon age measurements on two igneous rocks from the Ordovician System of Scotland. Nature, 205, 352-353.

2108

Harte, B., Booth, J. E., Dempster, T. J., Fettes, D. J., Mendum, J. R. \& Watts, D. 1984. Aspects of the post-depositional evolution of Dalradian and Highland Border Complex rocks in the Southern Highlands of Scotland. Transactions of the Royal Society of Edinburgh: Earth Sciences, 75, 151-163.

2113

Harte, B. \& HudSON, N. F. C. 1979. Pelite facies series and the temperatures and pressures of Dalradian metamorphism. In: HARris, A. L., Holland, C. H. \& LEAKE, B. E. (eds.) The Caledonides of the British Isles reviewed. Geological Society, London, Special Publications, 8, 323-337.

2118

Henderson, W. G. \& Robertson, A. H. F. 1982. The Highland Border rocks and their relation to marginal basin development in the Scottish Caledonides. Journal of the Geological Society, London, 139, 433-450.

2124

Henderson, W. G., Tanner, P. W. G. \& Strachan, R. A. 2009. The Highland Border Ophiolite of Scotland: observations from the Highland Workshop field excursion of April 2008. Scottish Journal of Geology, 45, 13-18.

2126

2127

Highton, A. J., Hyslop, E. K. \& Noble, S. R. 1999. U-Pb zircon geochronology of migmatization in the northern Central Highlands: evidence for pre-Caledonian (Neoproterozoic) tectonometamorphism in the Grampian block, Scotland. Journal of the Geological Society, 156, 1195-1204.

2131

2132

Hodych, J. P. \& CoX, R. A. 2007. Ediacaran U-Pb zircon dates for the Lac Matapedia and Mt.

2133 St.-Anselme basalts of the Quebec Appalachians: support for a long-lived mantle plume 2134 during the rifting phase of Iapetus opening. Canadian Journal of Earth Sciences, 44, 5652135581.

2136

2137 Holdsworth, R., STRACHAN, R. \& HARRIS, A. 1994. Precambrian rocks in northern Scotland 2138 east of the Moine Thrust: the Moine Supergroup. In: GibBons, W. \& HarRis, A. L. (eds.) $A$ 2139 Revised Correlation of Precambrian Rocks in the British Isles. Geological Society, London, 2140 Special Reports, 22, 23-32. 
2142 HoldsworTh, R. E. 1987. Basement/cover relationships, reworking and Caledonian ductile

2143 thrusts of the Northern Moine, NW Scotland. PhD thesis, University of Liverpool.

2144

2145

HoldsworTh, R. E. 1989. The geology and structural evolution of a Caledonian fold and

2146 ductile thrust zone, Kyle of Tongue Region, Sutherland, northern Scotland. Journal of the 2147 Geological Society, 146, 809-823.

2148

2149

Holdsworth, R. E., Alsop, G. I. \& Strachan, R. A. 2007. Tectonic stratigraphy and

2150 structural continuity of the northernmost Moine Thrust Zone and Moine Nappe, Scottish

2151 Caledonides. In: RIES, A. C. (ed.) Global Tectonic Processes. Geological Society, London, Special Publications, 272, 121-142.

2153

2154

Holdsworth, R. E. \& RoBerts, A. M. 1984. Early curvilinear fold structures and strain in 2155 the Moine of the Glen Garry Region, Inverness-shire. Journal of the Geological Society, 2156

2157

2158 141, 327-338.

2159

Holdsworth, R. E., Strachan, R. A. \& Alsop, G. I. 2001. Geology of the Tongue District. Memoir of the British Geological Survey. HMSO.

2160

2161

Holdsworth, R. E., Tavarnelli, E., ClegG, P., Pinheiro, R. V. L., Jones, R. R. \& McCaffrey, K. J. 2162

2163 W. 2002. Domainal deformation patterns and strain partitioning during transpression: an example from the Southern Uplands terrane, Scotland. Journal of the Geological 2164 Society, 159, 401-415.

2165

2166

Holland, C. H. 2009. Silurian. In: Holland, C. H. \& SAnders, I. S. (eds.) The Geology of 2167 Ireland, 2nd edition. Dunedin Academic Press, Edinburgh, 119-142.

2168

2169

Hollis, S. P., Roberts, S., Cooper, M. R., Earls, G., Herrington, R., Condon, D. J., Cooper, M. J., 2170 ARChibAlD, S. M. \& PierCEY, S. J. 2012. Episodic arc-ophiolite emplacement and the growth of continental margins: Late accretion in the Northern Irish sector of the GrampianTaconic orogeny. Geological Society of America Bulletin, 124, 1702-1723.

2173

2174

Hutchison, A. R. \& Oliver, G. J. H. 1998. Garnet provenance studies, juxtaposition of

2175 Laurentian marginal terranes and timing of the Grampian orogeny in Scotland. Journal 2176 of the Geological Society, London, 155, 541-550.

2177

2178 Hutton, D. H. W., Aftalion, M. \& Halliday, A. N. 1985. An Ordovician ophiolite in County 2179 Tyrone, Ireland. Nature, 315, 210-212.

2180 
2181 Hutton, D.H.W. \& Dewey, J.F. (1986) Palaeozoic terrane accretion in the Irish 2182 Caledonides. Tectonics, 5(7), 1115-1124.

2183

2184

Hutton, D. H. W. \& Holland, C. H. 1992. An Arenig-Llanvirn age for the black shales of

2185

Slieve Gallion, County Tyrone. Irish Journal of Earth Sciences, 11, 187-189.

2186

2187

HutTon, D. H. W. \& Alsop, G. I. 1995. Extensional geometries as a result of regional scale

2188

thrusting: tectonic slides of the Dunlewy-NW Donegal area, Ireland. Journal of Structural

2189

Geology, 17, 1279-1292.

2190

2191

HutTon, D.H.W. \& AlsoP, G.I. 2004. Evidence for a major Neoproterozoic unconformity

2192

2193

within the Dalradian Supergroup of NW Scotland. Journal of the Geological Society, London, 161, 629-640.

2194

2195

INCE, D. 1984. Sedimentation and tectonism in the Middle Ordovician of the Girvan

2196 district, SW Scotland. Transactions of the Royal Society of Edinburgh: Earth Sciences, 75, 2197 225-237.

2198

2199

INGHAM, J. 1978. Geology of a continental margin 2: middle and late Ordovician 2200 transgression, Girvan. In: Bowes, R. D. \& LEAKE, B. E. (eds.) Crustal Evolution in 2201 Northwestern Britain and Adjacent Regions. Geological Journal Special Issue 10, Seel 2202 House Press, Liverpool, 163-176.

2203

2204

Johnson, M. R. W. 1991. Dalradian. In: Craig, G. Y. (ed.) Geology of Scotland, $3^{\text {rd }}$ edition. 2205 The Geological Society, Bath, 125-160.

2206

2207

2208

2209

Johnson, M. R. W., Kelley, S. P., Oliver, G. J. H. \& Winter, D. A. 1985. Thermal effects and timing of thrusting in the Moine Thrust Zone. Journal of the Geological Society, 142, 863873.

2210

2211

Johnson, M. R. W. \& Strachan, R. A. 2006. A discussion of possible heat sources during 2212 nappe stacking: the origin of Barrovian metamorphism within the Caledonian thrust 2213 sheets of NW Scotland. Journal of the Geological Society, 163, 579-582.

2214

2215 KAMO, S. L., GowER, C. F. \& KRoGH, T. E. 1989. Birthdate for the Iapetus Ocean? A precise U$2216 \mathrm{~Pb}$ zircon and baddelyite age for the Long Range dikes, southeast Labrador. Geology, 17, 2217 602-605.

2218 
2219 Kelley, S. 1988. The relationship between K-Ar mineral ages, mica grain sizes and 2220 movement on the Moine Thrust Zone, NW Highlands, Scotland. Journal of the Geological 2221 Society, 145, 1-10.

2222

2223

Kelley, S. \& Bluck, B. J. 1989. Detrital mineral ages from the Southern Uplands using 2224 ${ }^{40} \mathrm{Ar}-{ }^{39} \mathrm{Ar}$ laser probe. Journal of the Geological Society, 146, 401-403.

2225

2226

Kelley, S. P. \& Powell, D. 1985. Relationships between marginal thrusting and 2227 movement on major, internal shear zones in the Northern Highland Caledonides, Scotland. Journal of Structural Geology, 7, 161-174.

2229

2230

Kelling, G., Davies, P. \& Holroyd, J. 1987. Style, scale and significance of sand bodies in the Northern and Central Belts, southwest Southern Uplands. Journal of the Geological 2232 Society, 144, 787-805.

2233

2234

Kennedy, M. J. 1980. Serpentinite-bearing melange in the Dalradian of County Mayo and 2235 its significance in the development of the Dalradian basin. Journal of Earth Sciences of the Royal Dublin Society, 3, 117-126.

Kennedy, M. J. \& Menuge, J. F. 1992. The Iniskea Division of northwest Mayo: Dalradian cover rather than pre-Caledonian basement. Journal of the Geological Society, London, 149, 167-170.

2241

KEnNEDY, W. Q. 1951. Sedimentary differentiation as a factor in the Moine-Torridonian correlation. Geological Magazine, 88, 257-266.

Kimbell, G. S. \& Stone, P. 1995. Crustal magnetization variations across the Iapetus 2246 Suture Zone. Geological Magazine, 132, 599-609.

Kinnaird, T., Prave, A., Kirkland, C., Horstwood, M., Parrish, R. \& Batchelor, R. 2007. The late Mesoproterozoic-early Neoproterozoic tectonostratigraphic evolution of NW Scotland: the Torridonian revisited. Journal of the Geological Society, 164, 541-551.

2252 KinnY, P. D., Friend, C. R. L. \& Love, G. J. 2005. Proposal for a terrane-based nomenclature 2253 for the Lewisian Gneiss Complex of NW Scotland. Journal of the Geological Society, 162, 2254 175-186.

2255

2256 Kinny, P. D., Friend, C. R. L., Strachan, R. A., Watt, G. R. \& Burns, I. M. 1999. U-Pb 2257 geochronology of regional migmatites in East Sutherland, Scotland: evidence for crustal 
2258

2259

2260

2261

2262

2263

2264

2265

2266

2267

2268

2269

2270

2271

2272

2273

2274

2275

2276

2277

2278

2279

2280

2281

2282

2283

2284

2285

2286

2287

2288

2289

2290

2291

2292

2293

2294

2295

2296 melting during the Caledonian orogeny. Journal of the Geological Society, London, 156, 1143-1152.

Kinny, P. D., Strachan, R. A., Friend, C. R. L., Kocks, H., Rogers, G. \& Paterson, B. A. 2003. U$\mathrm{Pb}$ geochronology of deformed metagranites in central Sutherland, Scotland: evidence for widespread late Silurian metamorphism and ductile deformation of the Moine Supergroup during the Caledonian orogeny. Journal of the Geological Society, 160, 259269.

KinnY, P. D., Strachan, R. A., Kocks, H. \& Friend, C. R. L. 2003. U-Pb geochronology of late Neoproterozoic augen granites in the Moine Supergroup, NW Scotland: dating of riftrelated, felsic magmatism during supercontinent break-up? Journal of the Geological Society, London, 160, 925-934.

Kirkland, C. L., Bingen, B., Whitehouse, M. J., Beyer, E. \& Griffin, W. L. 2011. Neoproterozoic palaeogeography in the North Atlantic Region: Inferences from the Akkajaure and Seve Nappes of the Scandinavian Caledonides. Precambrian Research, 186, $127-146$.

Kirkland, C. L., Strachan, R. A. \& Prave, A. R. 2008. Detrital zircon signature of the Moine Supergroup, Scotland: Contrasts and comparisons with other Neoproterozoic successions within the circum-North Atlantic region. Precambrian Research, 163, 332350.

Kocks, H., Strachan, R. A. \& Evans, J. A. 2006. Heterogeneous reworking of Grampian metamorphic complexes during Scandian thrusting in the Scottish Caledonides: insights from the structural setting and U-Pb geochronology of the Strath Halladale Granite. Journal of the Geological Society, 163, 525-538.

Krabbendam, M., Prave, T. \& Cheer, D. 2008. A fluvial origin for the Neoproterozoic Morar Group, NW Scotland; implications for Torridon-Morar Group correlation and the Grenville Orogen foreland basin. Journal of the Geological Society, 165, 379-394.

Krabbendam, M., Strachan, R. A., Leslie, A. G., Goodenough, K. M. \& Bonsor, H. C. 2011. The internal structure of the Moine Nappe Complex and the stratigraphy of the Morar Group in the Fannichs-Beinn Dearg area, NW Highlands. Scottish Journal of Geology, 47, 1-20.

Lambert, R. S. J. \& McKerrow, W. S. 1976. The Grampian Orogeny. Scottish Journal of Geology, 12, 271-292. 
LAW, R. D. \& Johnson, M. R. W. 2010. Microstructures and crystal fabrics of the Moine thrust zone and Moine nappe: history of research and changing tectonic interpretations. In: LaW, R., Butler, R. W. H., Holdsworth, R. E., KrabbendaM, M. \& Strachan, R. A. (eds.) Continental tectonics and mountain building: the legacy of Peach and Horne Geological 2302 Society, London, Special Publications, 335, 443-503.

2303

2304

LEGGETT, J. K. 1987. The Southern Uplands as an Accretionary Prism - the Importance of 2305 analogs in reconstructing paleogeography. Journal of the Geological Society, 144, 737752.

2307

2308

LegGetT, J. K., McKerrow, W. S. \& Eales, M. H. 1979. The Southern Uplands of Scotland; a 2309 Lower Paleozoic accretionary prism. Journal of the Geological Society, 136, 755-770.

2310

2311

LeSlie, A. G., SMith, M. \& SoPER, N. 2008. Laurentian margin evolution and the Caledonian orogeny - a template for Scotland and East Greenland. In: HigGins, A. K., GILOTTI, J. A. \& Smith, M. P. (eds.) The Greenland Caledonides: Evolution of the Northeast Margin of Laurentia. Geological Society of America Memoirs, 202, 307-343.

2315

Leslie, G. 2009. Border skirmish. Geoscientist, 19, 16-20.

2317

Li, Z. X., Bogdanova, S. V., Collins, A. S., Davidson, A., De Waele, B., Ernst, R. E., Fitzsimons, I. C. W., Fuck, R. A., Gladkochub, D. P., Jacobs, J., Karlstrom, K. E., Lu, S., Natapov, L. M., Pease, V., Pisarevsky, S. A., Thrane, K. \& Vernikovsky, V. 2008. Assembly, configuration, and break-up history of Rodinia: A synthesis. Precambrian Research, 160, 179-210.

2322

Longman, C. D., Bluck, B. J. \& VAn Breemen, 0. 1979. Ordovician conglomerates and the 2324 evolution of the Midland Valley. Nature, 280, 578-581.

2325

NeEdham, D. 1993. The structure of the western part of the Southern Uplands of 2327 Scotland. Journal of the Geological Society, 150, 341-354.

2328

2329

Macdonald, R. \& FetTes, D. J. 2006. The tectonomagmatic evolution of Scotland. Transactions of the Royal Society of Edinburgh-Earth Sciences, 97, 213-295.

2331

2332

MacQueen, J. A. \& Powell, D. 1977. Relationships between Deformation and Garnet 2333 Growth in Moine (Precambrian) Rocks of Western Scotland. Geological Society of 2334 America Bulletin, 88, 235-240.

2335 
2336

2337

2338

2339

2340

2341

2342

2343

2344

2345

2346

2347

2348

2349

2350

2351

2352

2353

2354

2355

2356

2357

2358

2359

2360

2361

2362

2363

2364

2365

2366

2367

2368

2369

2370

2371

2372

2373

2374

Mange, M., IDleman, B., Yin, Q. Z., HidAKA, H. \& DeweY, J. 2010. Detrital heavy minerals, white mica and zircon geochronology in the Ordovician South Mayo Trough, western Ireland: signatures of the Laurentian basement and the Grampian orogeny. Journal of the Geological Society, 167, 1147-1160.

Marcantonio, F., Dickin, A. P., McNutt, R. H. \& Heaman, L. M. 1988. A 1,800-million-yearold Proterozoic gneiss terrane in Islay with implications for the crustal structure and evolution of Britain. Nature, 353, 62-64.

MaX, M. D. 1989. The Clew Bay Group: a displaced terrane of Highland Border Group rocks (Cambro-Ordovician) in northwest Ireland. Geological Journal, 24, 1-17.

MaX, M. D. \& LonG, C. B. 1985. Pre-Caledonian basement in Ireland and its cover relationships. Geological Journal, 20, 341-366.

MaX, M. D., Ryan, P. D. \& InAmDAR, D. D. 1983. A magnetic deep structural geology interpretation of Ireland. Tectonics, 2, 431-451.

MaX, M. D., Treloar, P. J., Winchester, J. A. \& Oppenheim, M. J. 1983. Cr mica from the Precambrian Erris Complex, NW Mayo, Ireland. Mineralogical Magazine, 47, 359-364.

McAteer, C. A., Daly, J. S., Flowerdew, M. J., Connelly, J. N., Housh, T. B. \& Whitehouse, M. J. 2010. Detrital zircon, detrital titanite and igneous clast U-Pb geochronology and basement-cover relationships of the Colonsay Group, SW Scotland: Laurentian provenance and correlation with the Neoproterozoic Dalradian Supergroup. Precambrian Research, 181, 21-42.

McAteer, C. A., Daly, J. S., Flowerdew, M. J., Whitehouse, M. J. \& Kirkland, C. L. 2010. A Laurentian provenance for the Dalradian rocks of north Mayo, Ireland, and evidence for an original basement-cover contact with the underlying Annagh Gneiss Complex. Journal of the Geological Society, 167, 1033-1048.

McCausland, P. J. A., VAn Der Voo, R. \& Hall, C. M. 2007. Circum-Iapetus paleogeography of the Precambrian-Cambrian transition with a new paleomagnetic constraint from Laurentia. Precambrian Research, 156, 125-152.

McCay, G. A., Prave, A. R., Alsop, G. I. \& Fallick, A. E. 2006. Glacial trinity: Neoproterozoic Earth history within the British-Irish Caledonides. Geology, 34, 909-912. 
2375 McClay, K. R. \& Coward, M. P. 1981. The Moine Thrust zone: an overview. In: McClay, K.

2376 R. \& Price, N. J. (eds.) Thrust and Nappe Tectonics. Geological Society, London, Special 2377 Publications, 9, 241-260.

2378

2379

McConnell, B., Riggs, N. \& Crowley, Q. G. 2009. Detrital zircon provenance and 2380 Ordovician terrane amalgamation, western Ireland. Journal of the Geological Society, 2381 166, 473-484.

2382

2383

2384

McKerrow, W. S., MacNiocaill, C. \& Dewey, J. F. 2000. The Caledonian Orogeny redefined. Journal of the Geological Society, London, 157, 1149-1154.

2385

2386

MCKIE, T. 1990. Tidal and storm influenced sedimentation from a Cambrian transgressive passive margin sequence. Journal of the Geological Society, 147, 785-794.

2388

2389

Mendum, J. R. \& Thomas, C. W. 1997. Discussion on the generation of the Tay Nappe,

Scotland, by large-scale SE-directed shearing: Comment. Journal of the Geological

Society, London, 154, 581-583.

2392

2393

Mezger, K., Essene, E. J. \& Halliday, A. J. 1992. Closure temperatures of the Sm-Nd system 2394

2395

2396 in metamorphic garnets. Earth and Planetary Science Letters, 113, 397-409.

Moffat, D. T. 1987. The serpentinized ultramafites of the Shetland Caledonides. PhD 2397

2398

2399 thesis, University of Liverpool.

Moorhouse, V. E. 1979. The geology and geochemistry of the Bettyhill-Strathy area of 2400 north-east Sutherland. PhD thesis, University of Hull.

2401

2402

Moorhouse, V. E. \& Moorhouse, S. J. 1983. The geology and geochemistry of the Strathy

2403

Complex of northeast Sutherland, Scotland. Mineralogical Magazine, 47, 123-137.

2404

2405

Muir, R. J., Ireland, T. R., Bentley, M. R., Fitches, W. R. \& Maltman, A. J. 1997. A Caledonian

2406

2407

age for the Kiloran Bay appinite intrusion on Colonsay, Inner Hebrides. Scottish Journal

2408

2409 of Geology, 33, 75-82.

2410

2411

Noble, S. R., Hyslop, E. K. \& Highton, A. J. 1996. High-precision U-Pb monazite geochronology of the c. 806 Ma Grampian Shear Zone and the implications for the evolution of the Central Highlands of Scotland. Journal of the Geological Society, London,

2412 153, 511-514.

2413 
2414 O'Driscoll, B., Day, J. M. D., Walker, R. J., Daly, J. S., McDonough, W. F. \& Piccoli, P. M. 2012.

2415 Chemical heterogeneity in the upper mantle recorded by peridotites and chromitites

2416 from the Shetland Ophiolite Complex, Scotland. Earth and Planetary Science Letters, 2417 333, 226-237.

2418

2419 Oliver, G. J. H., Stone, P. \& Bluck, B. J. 2002. The Ballantrae Complex and the Southern

2420 Uplands Terrane. In: Trewin, N. H. (ed.) Geology of Scotland, $4^{\text {th }}$ edition. The Geological 2421 Society, Bath, 167-200.

2422

2423

OLIVER, G. J. H., WILDE, S. A. \& WAN, Y. S. 2008. Geochronology and geodynamics of Scottish 2424 granitoids from the late Neoproterozoic break-up of Rodinia to Palaeozoic collision. 2425 Journal of the Geological Society, 165, 661-674.

2426

2427

Park, R. G., Stewart, A. D. \& Wright, D. T. 2002. The Hebridean terrane. In: Trewin, N. H. (ed.) Geology of Scotland, $4^{\text {th }}$ edition. The Geological Society, Bath, 45-80.

2431

Peach, B. N., Horne, J., Gunn, W., Clough, C. T. \& Hinxman, L. W. 1907. The geological structure of the Northwest Highlands of Scotland. Memoirs of the Geological Survey of

2433 Great Britain. HMSO, Glasgow.

Peters, D. 2001. A geochemical and geochronological assessment of the Great Glen Fault 2436 as a terrane boundary. PhD thesis, Keele University.

Phillips, E. R., BARnes, R. P., Merriman, R. J. \& FloYd, J. D. 1995. The tectonic significance of

Ordovician basic igneous rocks in the Southern Uplands, southwest Scotland. Geological 2440 Magazine, 132, 549-556.

Phillips, E. R., Evans, J. A., Stone, P., Horstwood, M. S. A., Floyd, J. D., Smith, R. A., Akhurst, 2443 M. C. \& Barron, H. F. 2003. Detrital Avalonian zircons in the Laurentian Southern 2444 Uplands terrane, Scotland. Geology, 31, 625-628.

Phillips, E., Smith, R., Stone, P., Pashley, V. \& Horstwood, M. 2009. Zircon age constraints on the provenance of Llandovery to Wenlock sandstones from the Midland Valley terrane of the Scottish Caledonides. Scottish Journal of Geology, 45, 131-146. 
2453 Phillips, F. C. 1937. A fabric study of some Moine schists and associated rocks. Quarterly

2454 Journal of the Geological Society, 93, 581-620.

2455

2456

PhILliPS, W. E. A. 1973. The pre-Silurian rocks of Clare Island, Co. Mayo, Ireland, and the

2457

age of the metamorphism of the Dalradian in Ireland. Journal of the Geological Society,

2458

London, 129, 585-606.

2459

2460

Piasecki, M. A. J. \& VAn BREemen, O. 1983. Field and isotopic evidence for a c. 750 Ma

2461

tectonothermal event in Moine rocks in the Central Highland region of the Scottish

2462

Caledonides. Transactions of the Royal Society of Edinburgh: Earth Sciences, 73, 119-134.

2463

2464

Pitcher, W. S. \& Berger, A. R. 1972. The Geology of Donegal: A Study of Granite

2465

Emplacement and Unroofing. Wiley-Interscience, New York and London, 435.

2466

2467

PowELL, D. 1974. Stratigraphy and structure of the western Moine and the problem of

2468

Moine orogenesis. Journal of the Geological Society, London, 130, 575-593.

2469

2470

Powell, D., Baird, A. W., Charnley, N. R. \& Jordan, P. J. 1981. The metamorphic

2471

environment of the Sgurr Beag Slide: a major crustal displacement zone in Proterozoic,

2472

Moine rocks of Scotland. Journal of the Geological Society, 138, 661-673.

2473

2474

Prave, A.R., Fallick, A.E., Thomas, C.W. \& Graham, C.M. 2009. A composite C-isotope

2475

profile for the Neoproterozoic Dalradian Supergroup of Scotland and Ireland. Journal of

2476

the Geological Society, London, 166, 845-857.

2477

2478 Prichard, H. M. 1985. The Shetland Ophiolite. In: Gee, D. G. \& Sturt, B. A. (eds.) The

2479 Caledonide Orogen - Scandinavia and Related Areas. Wiley \& Sons, New York, 1173-1184.

2480

2481 PRICHARD, H. M. \& LORD, R. A. 1993. An overview of the PGE concentrations in the

2482 Shetland ophiolite complex. In: Prichard, H. M., Alabaster, T., Harris, N. B. W. \& Neary, C.

2483 R. (eds.) Magmatic Processes and Plate Tectonics. Geological Society, London, Special 2484 Publications, 76, 273-294.

2485

2486 Rainbird, R. H., Hamilton, M. A. \& YounG, G. M. 2001. Detrital zircon geochronology and 2487 provenance of the Torridonian, NW Scotland. Journal of the Geological Society, 158, 15248827.

2489

2490 RAmSAY, J. G. 1958. Moine-Lewisian relations at Glenelg, Inverness-shire. Quarterly

2491 Journal of the Geological Society of London, 113, 487-523. 
RATHBONE, P. A. \& HARRIS, A. L. 1979. Basement-cover relationships at Lewisian inliers in 2494 the Moine rocks. In: HARris, A. L., Holland, C. H. \& LEAKE, B. E. (eds.) The Caledonides of the 2495 British Isles reviewed. Geological Society, London, Special Publications, 8, 101-107.

2497 READ, H. H. 1923. The geology of the country around Banff, Huntly and Turriff (Lower

2498 Banffshire and North-west Aberdeenshire). Memoir of the Geological Survey, Scotland, 2499 Sheets 86 and 96 (Scotland).

2500

2501

2502

READ, H. H. 1931. The geology of central Sutherland (East-central Sutherland and southwestern Caithness). Memoir of the Geological Survey of Great Britain. HMSO, Edinburgh, 2503238

2504

2505

READ, H. H. 1957. The Granite Controversy. Thomas Murby and Co., London, 430.

2506

2507

ReED, F. R. C. 1935. Palaeontological evidence of the age of the Craighead Limestone. 2508 Transactions of the Geological Society of Glasgow, 19, 341-372.

2509

2510

Roberts, A. M. \& Harris, A. L. 1983. The Loch Quoich Line - a limit of early Palaeozoic 2511 crustal reworking in the Moine of the northern Highlands of Scotland. Journal of the 2512

2513

2514

2515

2516

2517

Geological Society, 140, 883-892.

RoBerTs, D. 2003. The Scandinavian Caledonides: event chronology, palaeogeographic settings and likely, modern analogues. Tectonophysics, 365, 283-299.

Roberts, J. L. \& TreaguS, J. E. 1977. Polyphase generation of nappe structures in the 2519 Dalradian rocks of the southwest Highlands of Scotland. Scottish Journal of Geology, 13, 237-254.

2520

2521

2522

2523

2524

2525

RoberTSON, S. 1994. Timing of Barrovian metamorphism and 'Older' granite emplacement in relation to Dalradian deformation. Journal of the Geological Society, London, 151, 5-8.

2526

2527

2528 Rogers, G., Hyslop, E. K., Strachan, R. A., Paterson, B. A. \& Holdsworth, R. E. 1998. The 2529 structural setting and U-Pb geochronology of Knoydartian pegmatites in W Inverness- 
2530

2531

2532

2533

2534

2535

2536

2537

2538

2539

2540

2541

2542

2543

2544

2545

2546

2547

2548

2549

2550

2551

2552

2553

2554

2555

2556

2557

2558

2559

2560

2561

2562

2563

2564

2565

2566

2567

shire: evidence for Neoproterozoic tectonothermal events in the Moine of NW Scotland. Journal of the Geological Society, London, 155, 685-696.

Rogers, G., Kinny, P. D., Strachan, R. A., Friend, C. R. L. \& Paterson, B. A. 2001. U-Pb geochronology of the Fort Augustus granite gneiss: constraints on the timing of Neoproterozoic and Palaeozoic tectonothermal events in the NW Highlands of Scotland. Journal of the Geological Society, 158, 7-14.

Rooney, A.D., ChEw, D.M. \& SELBY, D. 2011. Re-Os geochronology of the NeoproterozoicCambrian Dalradian Supergroup of Scotland and Ireland: Implications for Neoproterozoic stratigraphy, glaciations and Re-Os systematics. Precambrian Research, 185, 202-214.

Rose, P. T. S. \& HARris, A. L. 2000. Evidence for the Lower Palaeozoic age of the Tay Nappe: the timing and nature of Grampian events in the Scottish Highland sector of the Laurentian Margin. Journal of the Geological Society, London, 157, 381-391.

Rotenberg, E., Davis, D. W., Amelin, Y., Ghosh, S. \& Bergquist, B. A. 2012. Determination of the decay-constant of ${ }^{87} \mathrm{Rb}$ by laboratory accumulation of ${ }^{87} \mathrm{Sr}$. Geochimica et Cosmochimica Acta, 85, 41-57.

Rushton, A. \& Phillips, W. E. A. 1973. A Protospongia from the Dalradian of Clare Island, Co. Mayo, Ireland. Palaeontology, 16, 223-230.

RYAN, P. D., FloYd, P. A. \& ARChER, J. B. 1980. The stratigraphy and petrochemisty of the Lough Nafooey Group (Tremadocian), western Ireland. Journal of the Geological Society, London, 137, 443-458.

RYAN, P. D., SAWAL, V. K. \& RoWland, A. S. 1983. Ophiolitic melange separates ortho- and para-tectonic Caledonides in western Ireland. Nature, 302, 50-52.

SANDERS, I. S., DALY, J. S. \& DAVIES, G. R. 1987. Late Proterozoic high-pressure granulite facies metamorphism in the north-east $\mathrm{Ox}$ inlier, north-west Ireland. Journal of Metamorphic Geology, 5, 69-85.

Sanders, I. S., Vancalsteren, P. W. C. \& Hawkesworth, C. J. 1984. A Grenville Sm-Nd Age for the Glenelg eclogite in northwest Scotland. Nature, 312, 439-440. 
SaWaki, Y., Shibuya, T., KaWai, T., Komiya, T., Omori, S., IIzUKa, T., Hirata, T., Windley, B. F. \& MARUYAMA, S. 2010. Imbricated ocean-plate stratigraphy and U-Pb zircon ages from tuff beds in cherts in the Ballantrae complex, SW Scotland. Geological Society of America Bulletin, 122, 454-464.

Smellie, J. L. \& Stone, P. 2001. Geochemical characteristics and geotectonic setting of early Ordovician basalt lavas in the Ballantrae Complex ophiolite, SW Scotland. Transactions of the Royal Society of Edinburgh-Earth Sciences, 91, 539-555.

Smith, M., Robertson, S. \& Rollin, K. E. 1999. Rift basin architecture and stratigraphical implications for basement-cover relationships in the Neoproterozoic Grampian Group of the Scottish Caledonides. Journal of the Geological Society, London, 156, 1163-1173.

Soper, N. J., Strachan, R. A., HoldSWorth, R. E., GaYer, R. A. \& GReiling, R. O. 1992. Sinistral transpression and the Silurian closure of Iapetus. Journal of the Geological Society, London, 149, 871-880.

SpraY, J. G. 1988. Thrust-related metamorphism beneath the Shetland Islands oceanic fragment, northeast Scotland. Canadian Journal of Earth Sciences, 25, 1760-1776.

SPRAY, J. G. \& Dunning, G. R. 1991. A U/Pb age for the Shetland Islands oceanic fragment, Scottish Caledonides: evidence from anatectic plagiogranites in 'layer 3' shear zones. Geological Magazine, 128, 667-671.

STEPHENSON, D. \& GoulD, D. 1995. British regional geology: the Grampian Highlands. $4^{\text {th }}$ edition. HMSO for the British Geological Survey, London, 261.

Stephenson, D., Mendum, J.R., Fettes, D.J. \& Leslie, A.G. 2013. The Dalradian rocks of Scotland: an introduction. Proceedings of the Geologists Association, 124, 3-82.

Stewart, A. D. 2002. The later Proterozoic Torridonian rocks of Scotland: their sedimentology, geochemistry and origin. Geological Society, London, Memoirs, 24.

Stone, P. 1995. Geology of the Rhinns of Galloway. Memoir of the British Geological Survey. HMSO, London.

Stone, P., Floyd, J. D., Barnes, R. P. \& Lintern, B. C. 1987. A sequential back-arc and foreland basin thrust duplex model for the Southern Uplands of Scotland. Journal of the Geological Society, 144, 753-764. 
2608 Stone, P., Kimbell, G. S. \& Henney, P. J. 1997. Basement control on the location of strike2609 slip shear in the Southern Uplands of Scotland. Journal of the Geological Society, 154, 2610 141-144.

2611

2612 STONE, P. \& MERRIMAN, R. J. 2004. Basin thermal history favours an accretionary origin for 2613 the Southern Uplands terrane, Scottish Caledonides. Journal of the Geological Society, 2614 161, 829-836.

2615

StRACHAN, R. A. \& EvANS, J. A. 2008. Structural setting and U-Pb zircon geochronology of the Glen Scaddle Metagabbro: evidence for polyphase Scandian ductile deformation in the Caledonides of northern Scotland. Geological Magazine, 145, 361-371.

Strachan, R. A. \& HoldSwORTH, R. E. 1988. Basement cover relationships and structure within the Moine Rocks of central and southeast Sutherland. Journal of the Geological Society, 145, 23-36.

2623

Strachan, R. A., Holdsworth, R. E., Krabbendam, M. \& Alsop, G. I. 2010. The Moine Supergroup of NW Scotland: insights into the analysis of polyorogenic supracrustal sequences. In: LAW, R., Butler, R. W. H., Holdsworth, R. E., KrabBendaM, M. \& Strachan, R. A. (eds.) Continental tectonics and mountain building: the legacy of Peach and Horne. Geological Society, London, Special Publications, 335, 233-254.

Stringer, P. \& Treagus, J. E. 1980. Non-axial Planar S 1 Cleavage in the Hawick Rocks of the Galloway Area, Southern Uplands, Scotland. Journal of Structural Geology, 2, 3172632 331.

SVEnNingSEN, O. M. 2001. Onset of seafloor spreading in the Iapetus Ocean at $608 \mathrm{Ma}$ 2635 precise age of the Sarek Dyke Swarm, northern Swedish Caledonides. Precambrian Research, 110, 241-254.

2640

2641 TANNER, P.W.G. 2005. Discussion on evidence for a major Neoproterozoic unconformity

2642 within the Dalradian Supergroup of NW Ireland. Journal of the Geological Society, 2643 London, 162, 221-222. 
2645 Tanner, P. W. G. 2007. The role of the Highland Border Ophiolite in the $\sim 470 \mathrm{Ma}$

2646 Grampian event, Scotland. Geological Magazine, 144, 597-602.

2647

2648 TANnER, P.W.G. 2008. Tectonic significance of the Highland Boundary Fault, Scotland.

2649 Journal of the Geological Society, 165, 915-921.

2650

2651

TAnner, P. W. G. \& Bluck, B. J. 1999. Current controversies in the Caledonides. Journal of

2652

the Geological Society, London, 156, 1137-1141.

2653

2654

TAnner, P. W. G. \& Evans, J. A. 2003. Late Precambrian U-Pb titanite age for peak regional

2655 metamorphism and deformation (Knoydartian orogeny) in the western Moine, Scotland.

2656 Journal of the Geological Society, 160, 555-564.

2657

2658

Tanner, P. W. G., Johnstone, G. S., Smith, D. I. \& Harris, A. L. 1970. Moinian stratigraphy

2659 and the problem of the central Ross-shire inliers. Geological Society of America Bulletin,

2660 81, 299-306.

2661

2662

Tanner, P. W. G. \& Sutherland, S. 2007. The Highland Border Complex, Scotland: a 2663 paradox resolved. Journal of the Geological Society, 164, 111-116.

2664

2665

Thirlwall, M. F. \& Bluck, B. J. 1984. Sm-Nd isotope and geological evidence that the

2666 Ballantrae 'ophiolite' is polygenetic. In: GASS, I. G., LipPard, S. J. \& Shelton, A. W. (eds.)

2667 Ophiolites and oceanic lithosphere. Geological Society, London, Special Publications, 13, 2668 215-230.

2669

2670

TReagus, J. E. 1987. The structural evolution of the Dalradian of the Central Highlands of Scotland. Transactions of the Royal Society of Edinburgh, 78, 1-15.

2672

2673

TreloAR, P. J., Bluck, B. J., Bowes, D. R. \& DudeK, A. 1980. Hornblende-garnet 2674 metapyroxenite beneath serpentinite in the Ballantrae complex of SW Scotland and its

2675 bearing on the depth provenance of obducted oceanic lithosphere. Transactions of the 2676 2677

2678 Turnbull, M. J. M., Whitehouse, M. J. \& Moorbath, S. 1996. New isotopic age 2679 determinations for the Torridonian, NW Scotland. Journal of the Geological Society, 153, 2680 955-964.

2681

2682 Upton, B. G. J., Aspen, P., Graham, A. \& Chapman, N. A. 1976. Pre-Paleozoic Basement of the 2683 Scottish Midland Valley. Nature, 260, 517-518. 
van Breemen, O., HallidaY, A. N., Johnson, M. R. W. \& Bowes, D. R. 1978. Crustal additions Issue. 10, 81-106.

van Breemen, O. \& Piasecki, M. A. J. 1983. The Glen Kyllachy Granite and Its bearing on the nature of the Caledonian Orogeny in Scotland. Journal of the Geological Society, 140, 4762.

van Breemen, O., Pidgeon, R. T. \& Johnson, M. R. W. 1974. Precambrian and Palaeozoic pegmatites in the Moines of northern Scotland. Journal of the Geological Society, 130, 2695 493-504.

2696

2697

van Staal, C. R., Chew, D. M., Skulski, T., McNicoll, V., Hibbard, J., Escayola, M. P. \& 2698 CASTONGUAY, S. in press. Were segments of the Appalachian Humber margin of Iapetus hyperextended? Geoscience Canada.

2700

2701

van Staal, C. R., Dewey, J. F., Mac Niocaill, C. \& McKerrow, W. S. 1998. The Cambrian-

2702 Silurian tectonic evolution of the northern Appalachians and British Caledonides: 2703 history of a complex, west and southwest Pacific-type segment of Iapetus. In: BLUNDELL, 2704 D. J. \& ScotT, A. C. (eds.) Lyell, the Past is the Key to the Present. Geological Society, 2705 London, Special Publications, 143, 199-242.

2706

2707

van Staal, C. R., Whalen, J. B., Valverde-Vaquero, P., Zagorevski, A. \& Rogers, N. 2009. Pre-

2708 Carboniferous, episodic accretion-related, orogenesis along the Laurentian margin of 2709 the northern Appalachians. In: Murphy, J. B., Keppie, J. D. \& Hynes, A. J. (eds.) Ancient 2710 orogens and modern analogues. Geological Society, London, Special Publications, 327, 2711 271-316.

2712

2713 Vance, D., Strachan, R. A. \& Jones, K. A. 1998. Extensional versus compressional settings 2714 for metamorphism: Garnet chronometry and pressure-temperature-time histories in 2715 the Moine Supergroup, northwest Scotland. Geology, 26, 927-930.

2717 Viete, D. R., Richards, S. W., Lister, G. S., Oliver, G. J. H. \& BANKS, G. J. 2010. Lithospheric2718 scale extension during Grampian orogenesis in Scotland. In: LAW, R., BuTLER, R. W. H., 2719 Holdsworth, R. E., Krabbendam, M. \& Strachan, R. A. (eds.) Continental tectonics and 2720 mountain building: the legacy of Peach and Horne. Geological Society, London, Special 2721 Publications, 335, 121-160.

2722 
2723 Vorhies, S. H. \& AGUE, J. J. 2011. Pressure-temperature evolution and thermal regimes in

2724 the Barrovian zones, Scotland. Journal of the Geological Society, 168, 1147-1166.

2725

2726

Waldron, J. W. F., Floyd, J. D., Simonetti, A. \& Heaman, L. M. 2008. Ancient Laurentian

2727 detrital zircon in the closing lapetus Ocean, Southern Uplands terrane, Scotland.

2728 Geology, 36, 527-530.

2729

2730

WALDRon, J. W. F. \& VAN STAAL, C. R. 2001. Taconian orogeny and the accretion of the

2731 Dashwoods block: A peri-Laurentian microcontinent in the Iapetus Ocean. Geology, 29, 2732 811-814.

2733

2734

WILKINSON, J. M. \& CANN, J. R. 1974. Trace elements and tectonic relationships of basaltic 2735 rocks in the Ballantrae Igneous Complex, Ayrshire. Geological Magazine, 111, 35-41.

2736

2737

Williams, A. 1962. The Barr and Lower Ardmillan Series (Caradoc) of the Girvan District,

2738 South-west Ayrshire, with a Description of the Brachiopoda. Memoir of the Geological 2739 Society of London, 3, 267.

2740

2741

Williams, H. \& HiscotT, R. N. 1987. Definition of the Iapetus rift-drift transition in 2742 western Newfoundland. Geology, 15, 1044-1047.

2743

2744 Wilson, D. \& SHEPHERD, J. 1979. Pelite facies series and the temperatures and pressures 2745 of Dalradian metamorphism. In: HARris, A. L., Holland, C. H. \& LEAKE, B. E. (EDS.) The 2746 Caledonides of the British Isles reviewed. Geological Society, London, Special Publications, $2747 \quad 8,669-675$.

2748

2749

Winchester, J. A. \& MAX, M. D. 1984. Geochemistry and Origins of the Annagh Division of

2750 the Precambrian Erris Complex, Nw County Mayo, Ireland. Precambrian Research, 25, 2751 397-414.

2752

2753 Winchester, J. A., Williams, H., MaX, M. D. \& Van StaAl, C. R. 1992. Does the Birchy 2754 Complex of Newfoundland extend into Ireland? Journal of the Geological Society, London, 2755 149, 159-162.

2756

2757 Wrafter, J. P. \& Graham, J. R. 1989. Ophiolitic detritus in the Ordovician sediments of

2758 South Mayo, Ireland. Journal of the Geological Society, London, 146, 213-215.

2759 
2760 YardleY, B. W. D. 1976. Deformation and metamorphism of Dalradian rocks and the

2761 evolution of the Connemara cordillera. Journal of the Geological Society, London, 132,

2762 521-542.

2763

2764 YARDLEY, B. W. D. 1980. Metamorphism and orogeny in the Irish Dalradian. Journal of the

2765 Geological Society, London, 137, 303-309.

2766

2767 Yardley, B. W. D., Barber, J. P. \& Gray, J. R. 1987. The metamorphism of the Dalradian

2768 rocks of western Ireland and its relation to tectonic setting. Philosophical transactions of

2769 the Royal Society of London, A321, 243-270.

2770

2771 Yardley, B. W. D. \& SEnior, A. 1982. Basic magmatism in Connemara, Ireland: evidence

2772 for a volcanic arc? Journal of the Geological Society, London, 139, 67-70.

2773

2774 YARDLEY, B. W. D., VINE, F. J. \& BALDWIN, C. T. 1982. The plate tectonic setting of NW Britain

2775 and Ireland in Late Cambrian and early Ordovician times. Journal of the Geological

2776 Society, London, 139, 455-463.

2777

2778 YounG, D. G. G. 1974. The Donegal Granite: a gravity analysis. Proceedings of the Royal 2779 Irish Academy, 74B, 63-73.

2780

2781 ZEH, A. \& MiLlAR, I. L. 2001. Metamorphic evolution of garnet-epidote-biotite gneiss from 2782 the Moine Supergroup, Scotland, and geotectonic implications. Journal of Petrology, 42, 2783 529-554. 

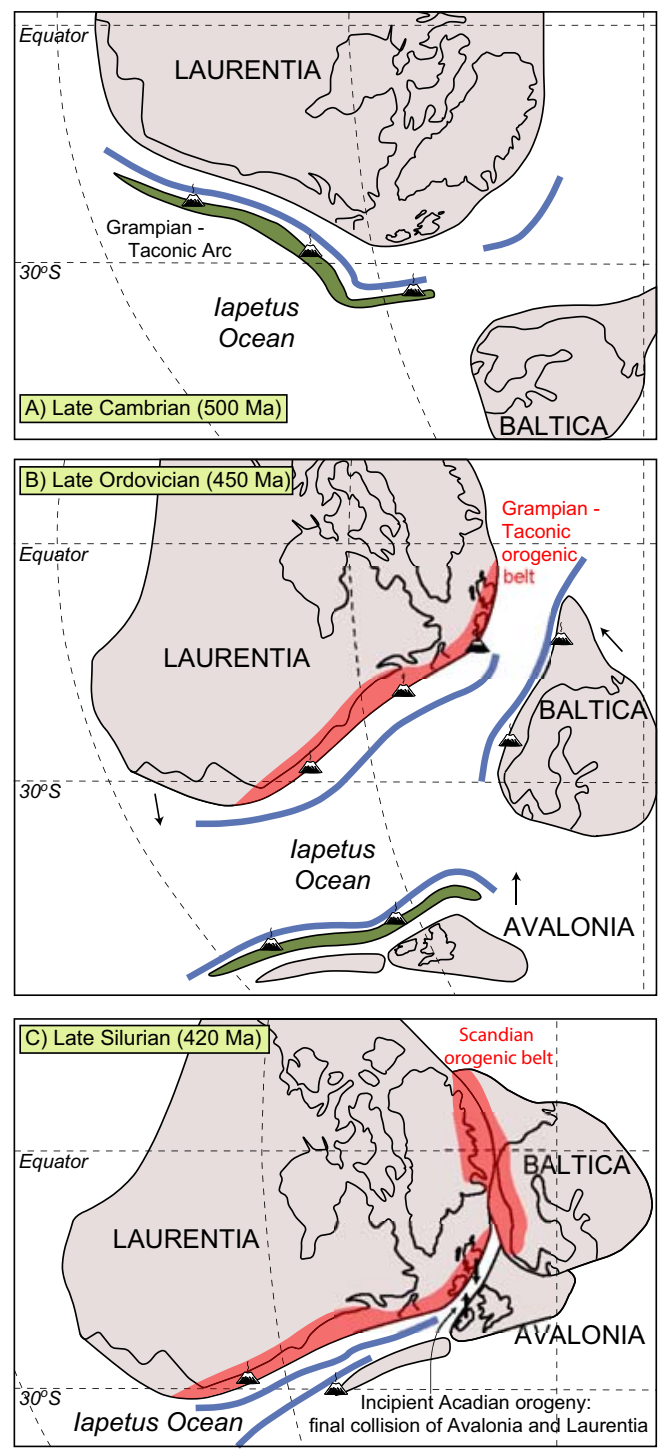

Figure 1 




Figure 2 


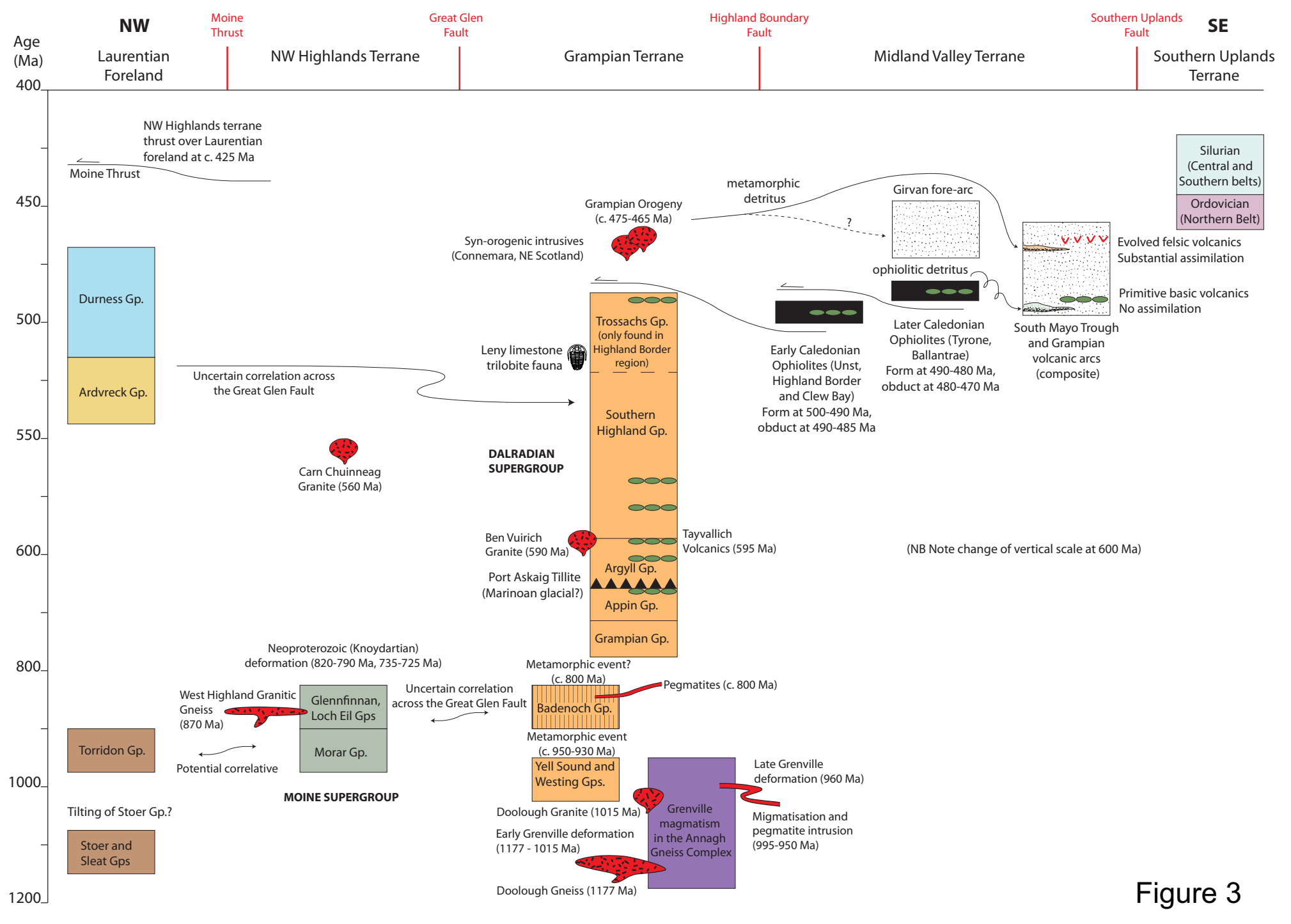




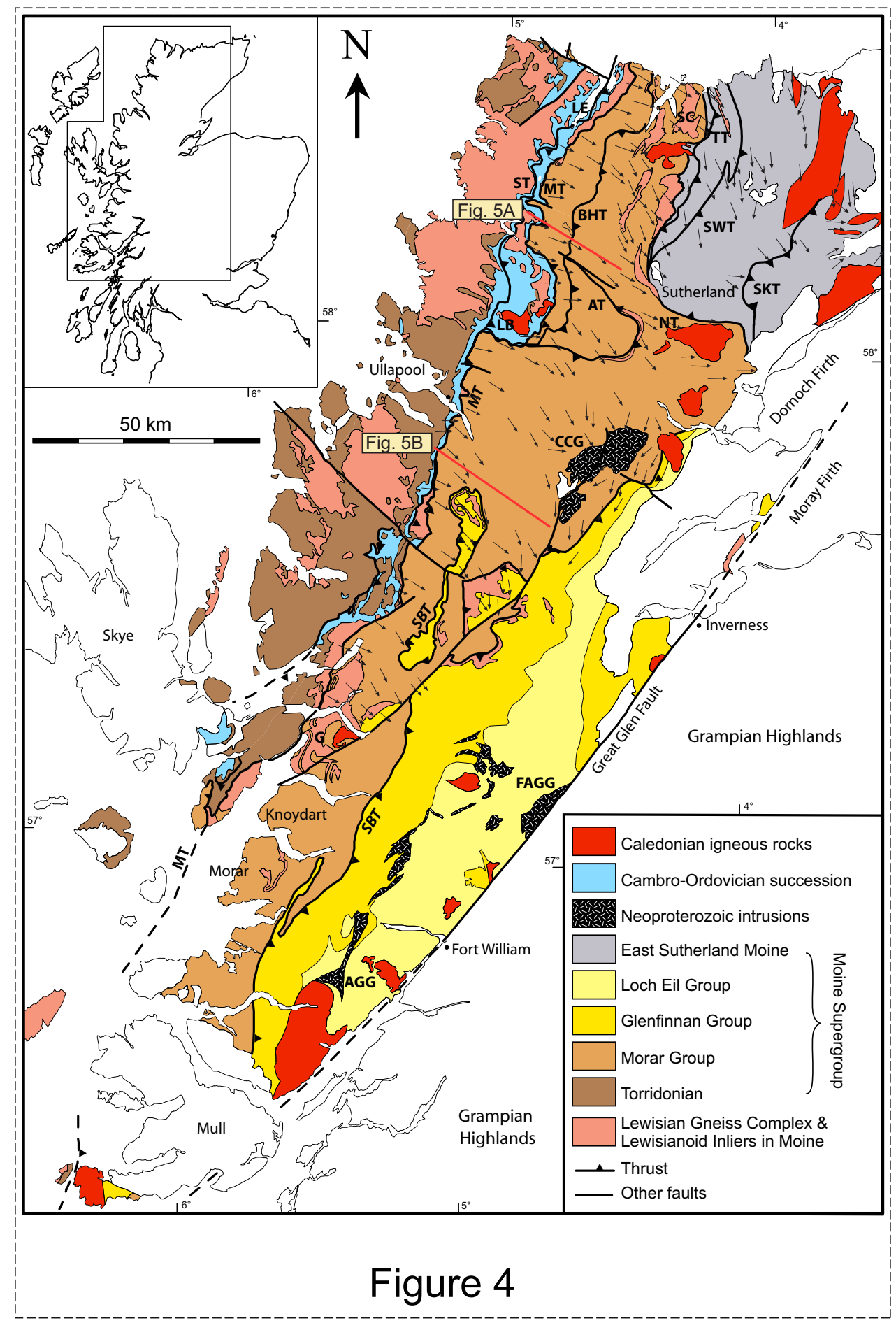




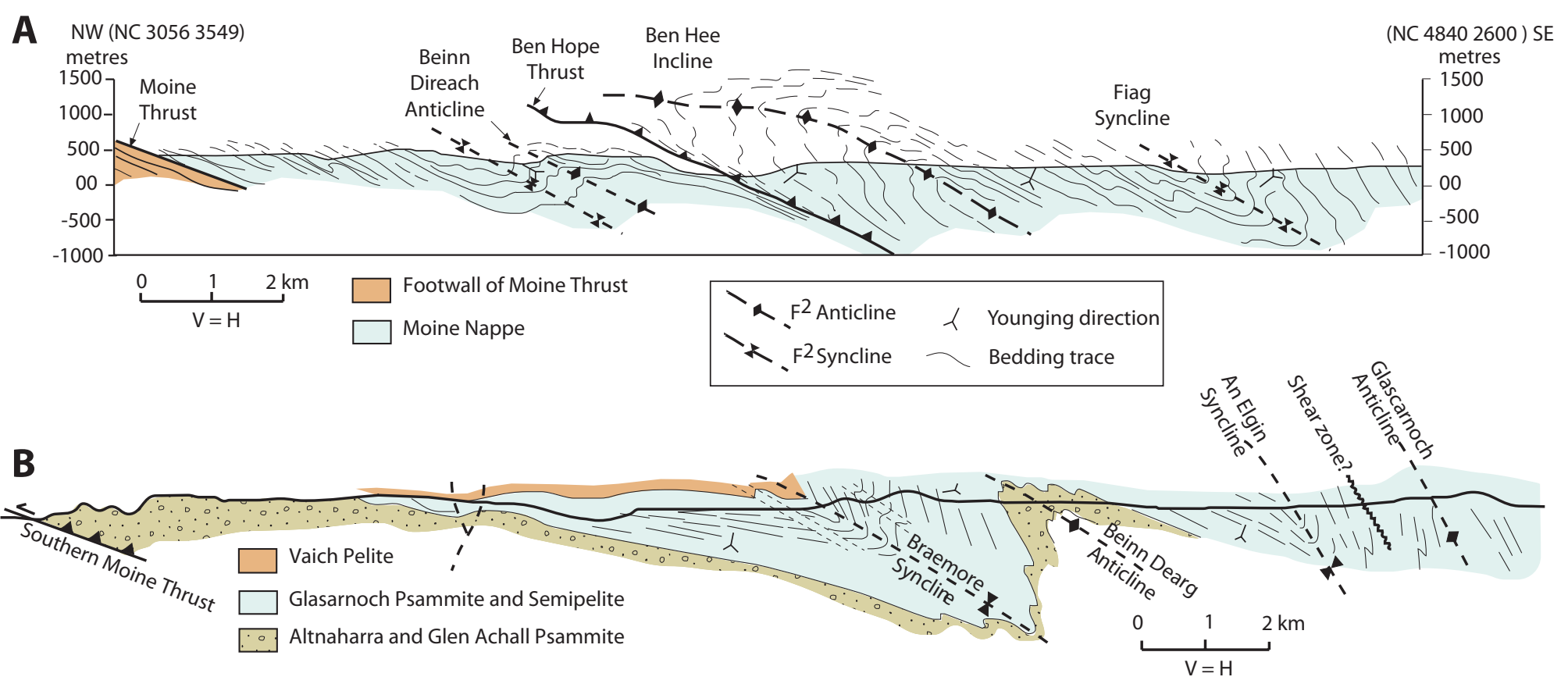

Figure 5 


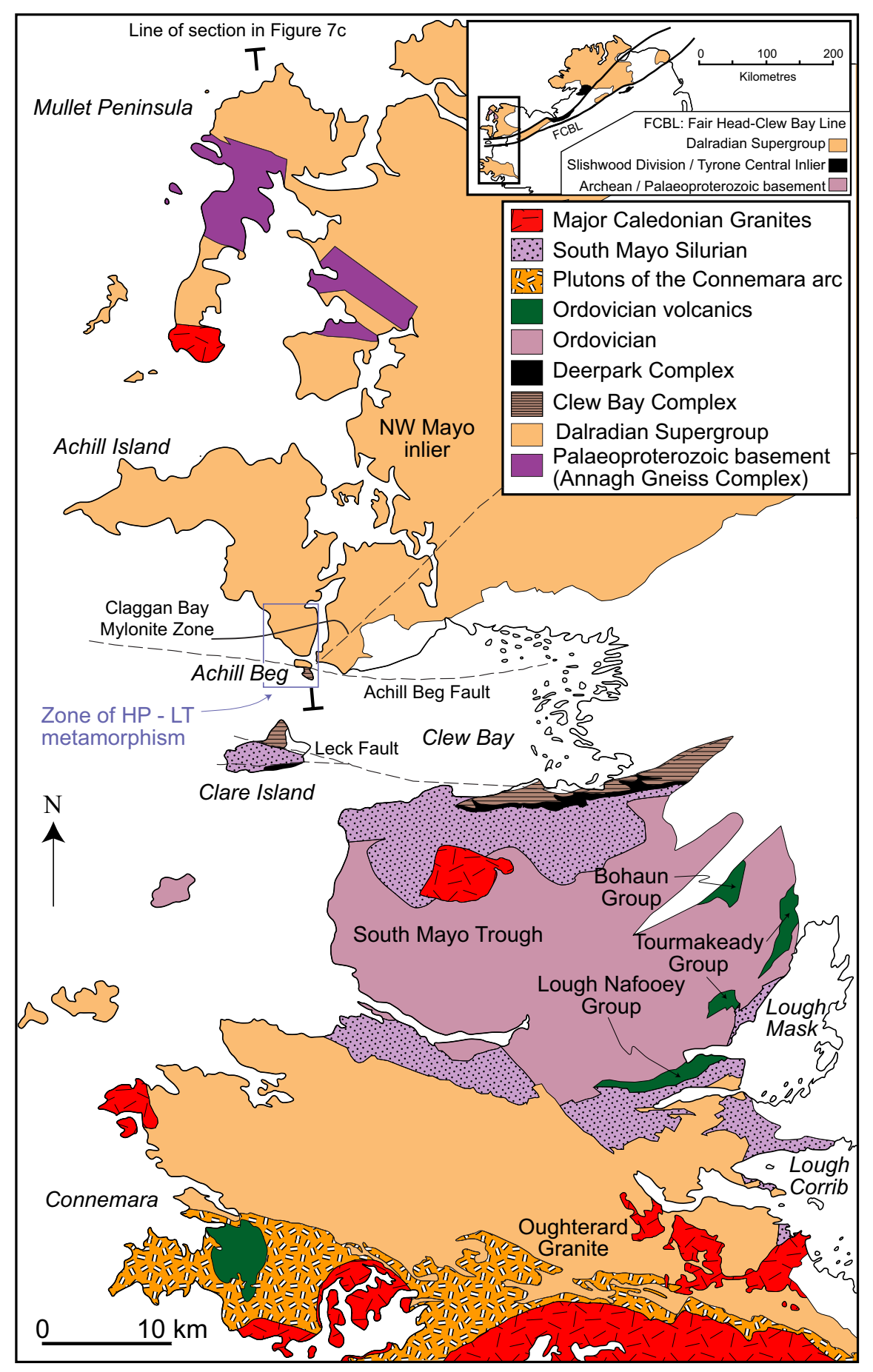

Figure 6 

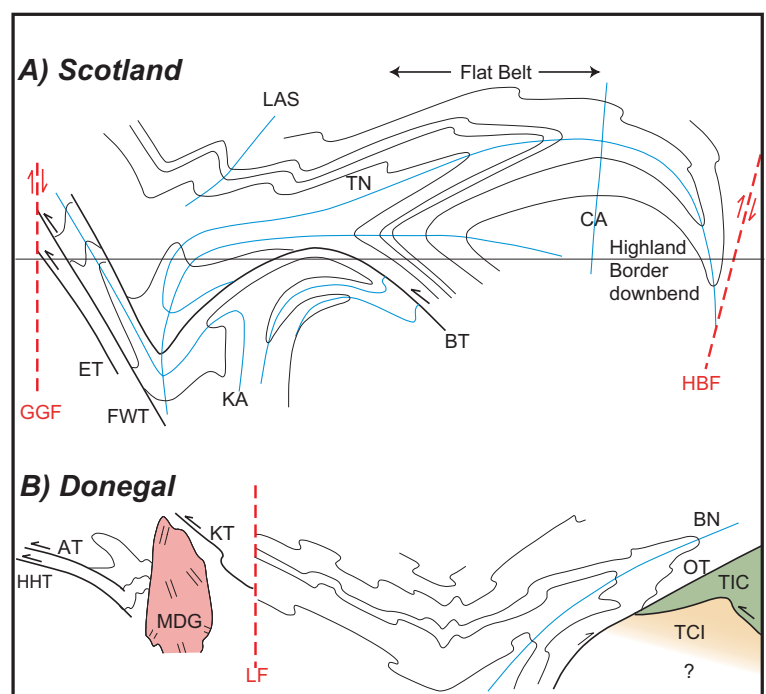

C) NW Mayo

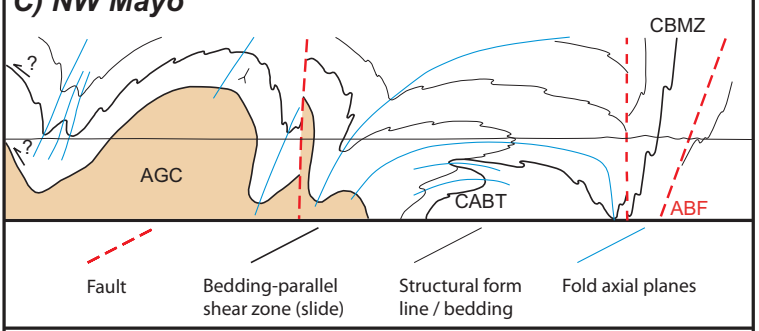

Scotland. BT: Boundary Thrust CA: Cowal Antiform ET: Eilrig Thrust

FWT: Fort William Thrust HBF: Highland Boundary Fault GGF: Great Glen Fault LAS: Loch Awe Synform KA: Kinlochleven Anticline TN: Tay Nappe

Donegal. AT: Ardsbeg Thrust BN: Ballybofey Nappe HHT: Horn Head Thrust

KT: Knockateen Thrust LF: Leenan Fault MDG: Main Donegal Granite

OT: Omagh Thrust TIC: Tyrone Igneous Complex TCl: Tyrone Central Inlier

NW Mayo. ABF: Achill Beg Fault AGC: Annagh Gneiss Complex

CABT: Central Achill Boundary Thrust CBMZ: Claggan Bay Mylonite Zone

\section{Figure 7}




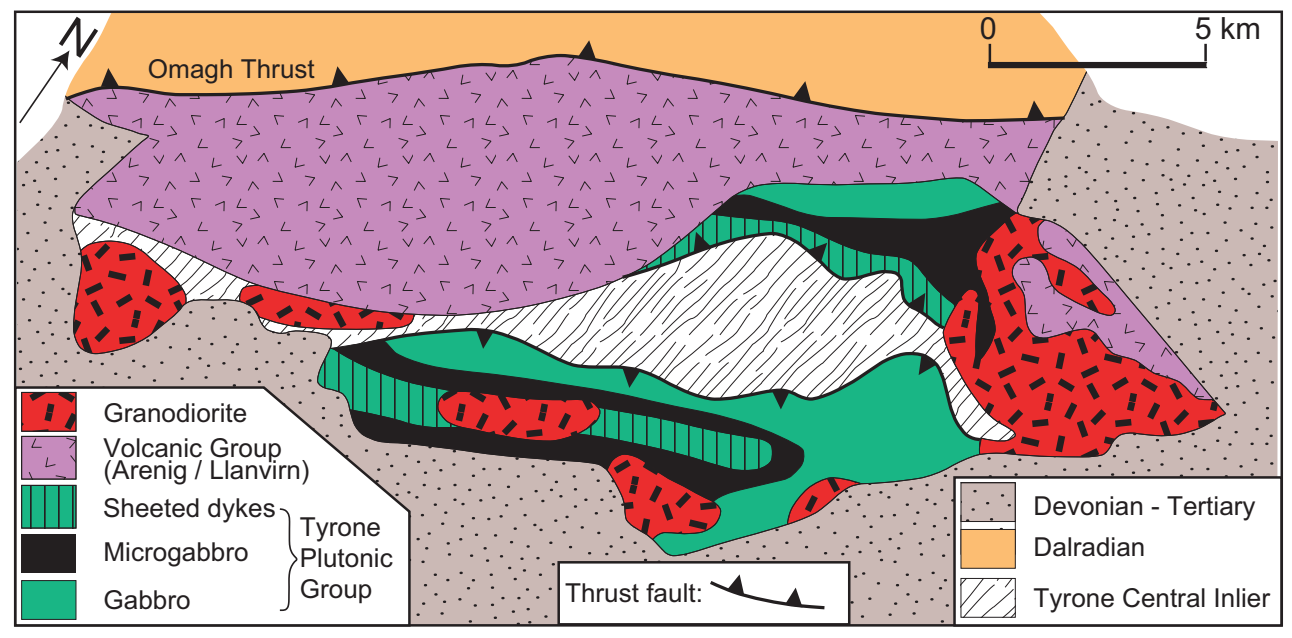

Figure 8 


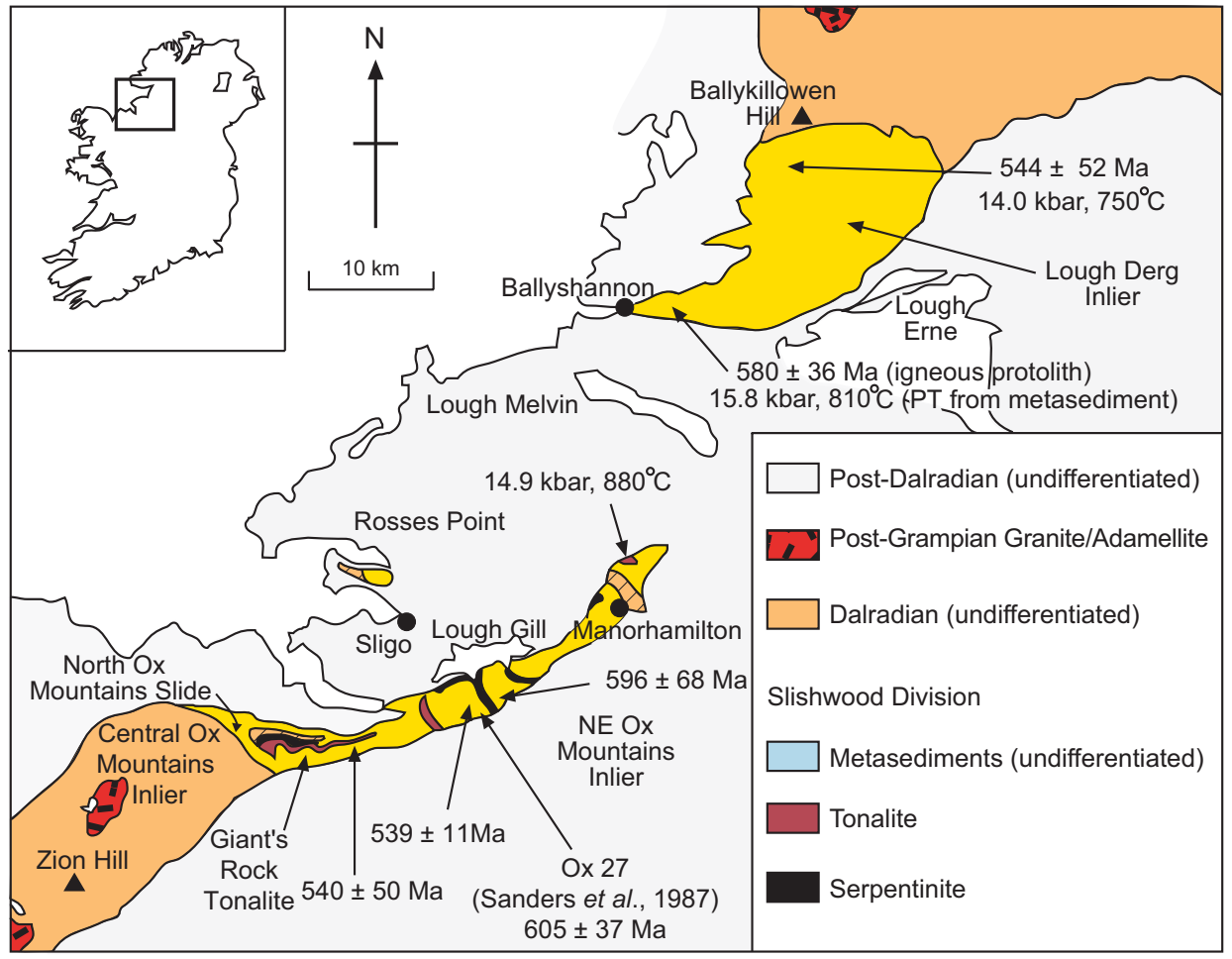

Figure 9 


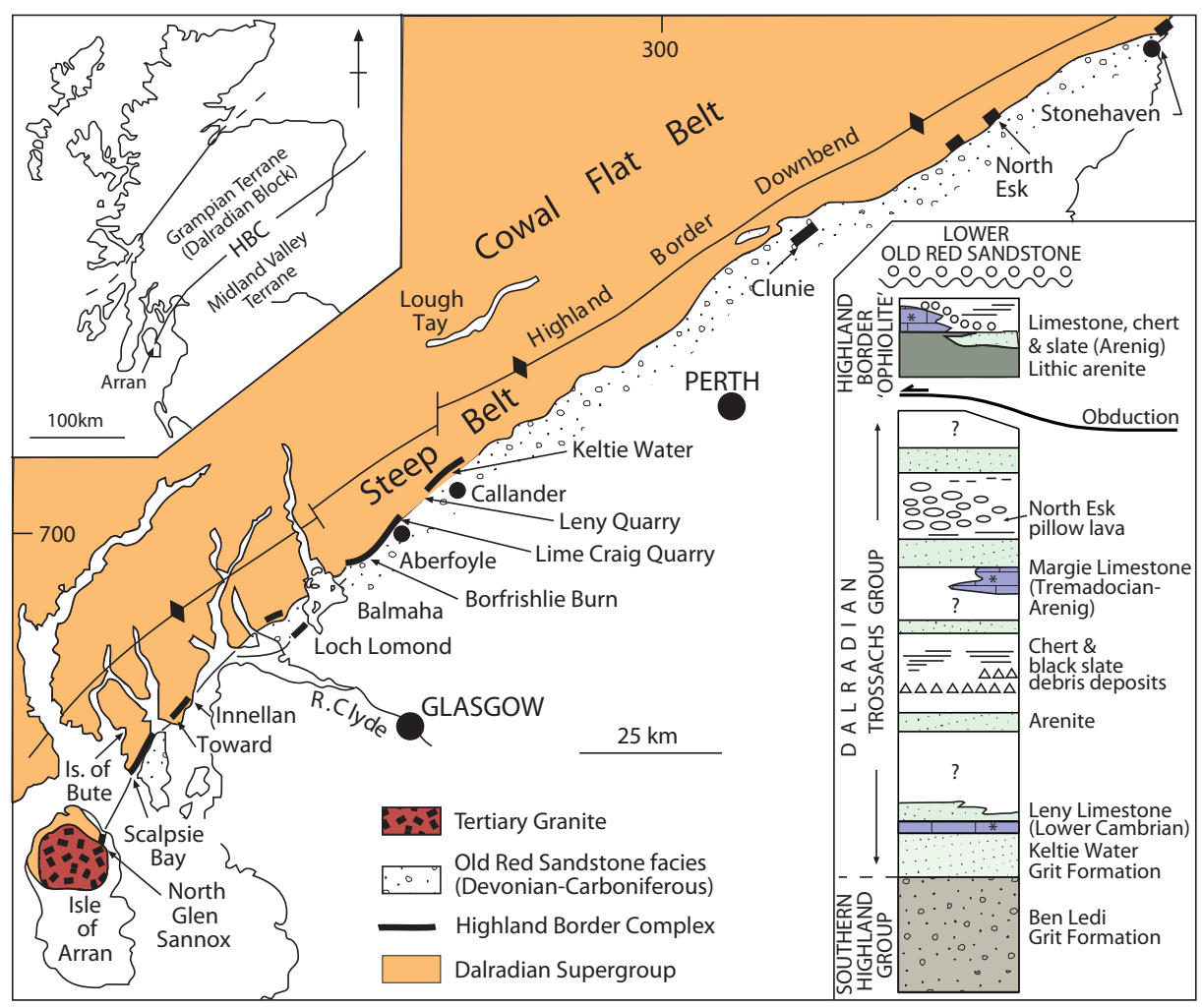

Figure 10 


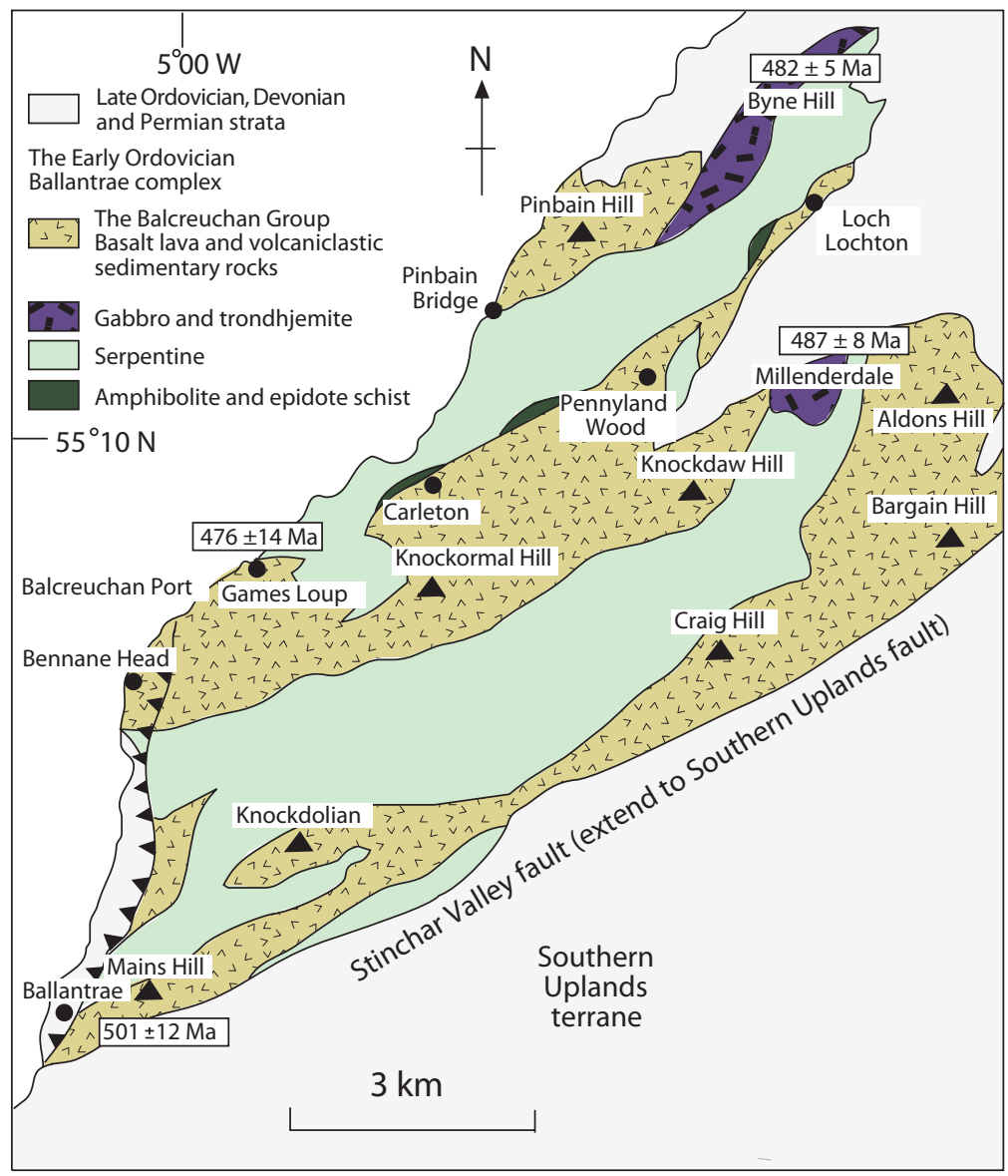

Figure 11 


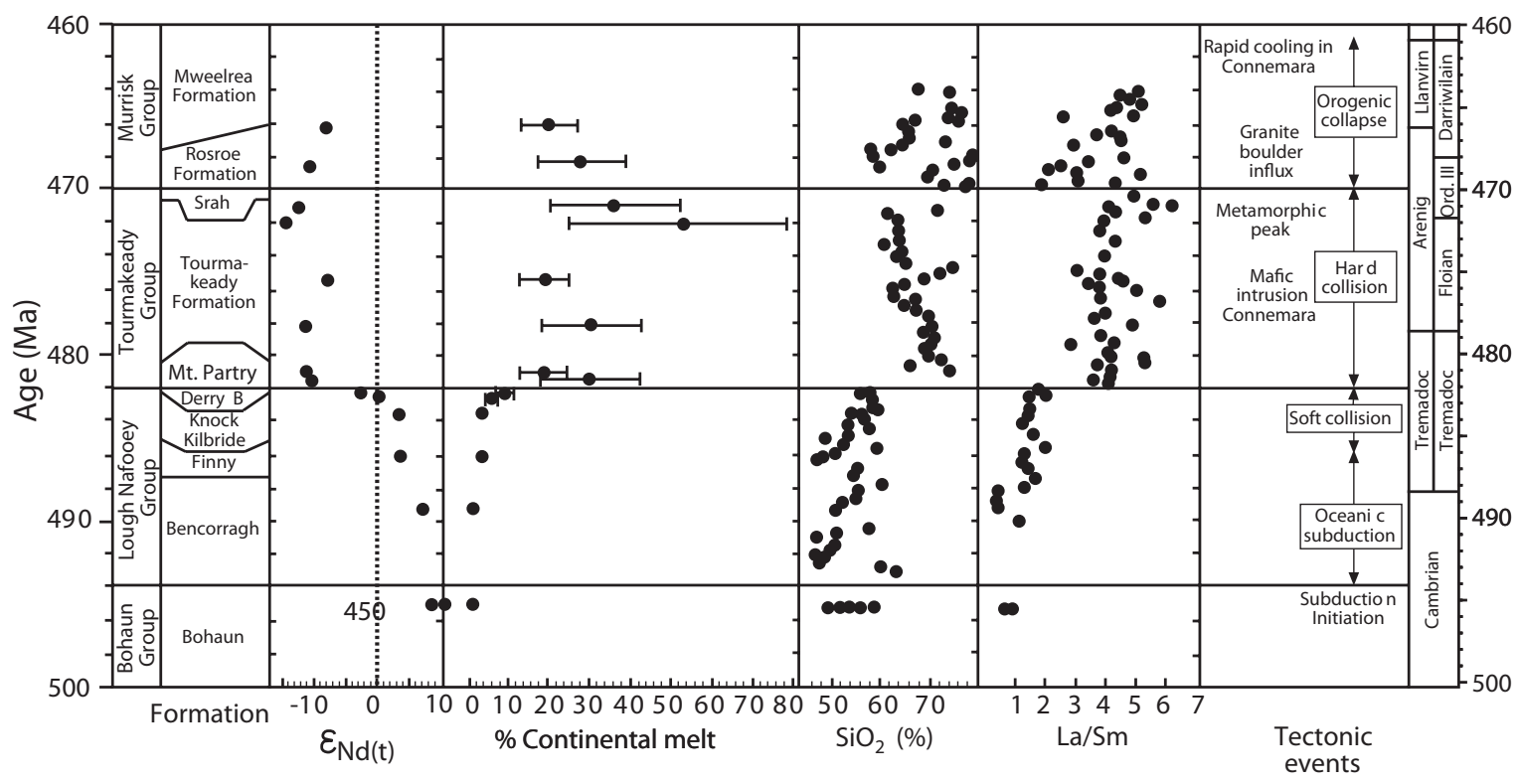

Figure 12 


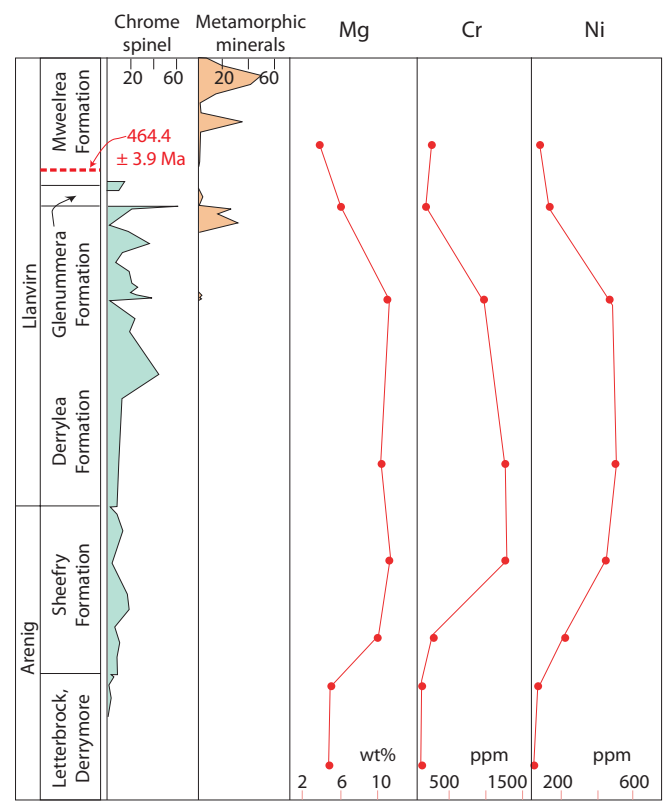

Figure 13 


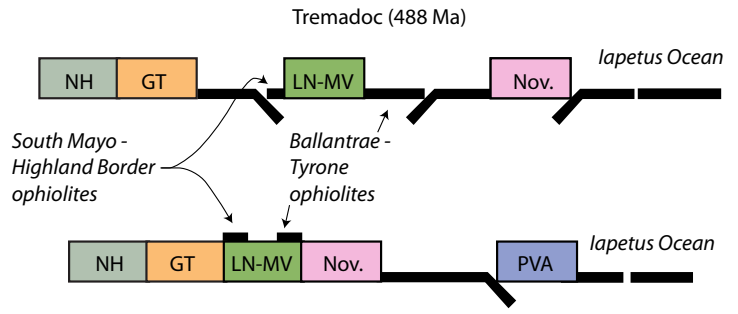

Late Arenig (465 Ma)

Figure 14 


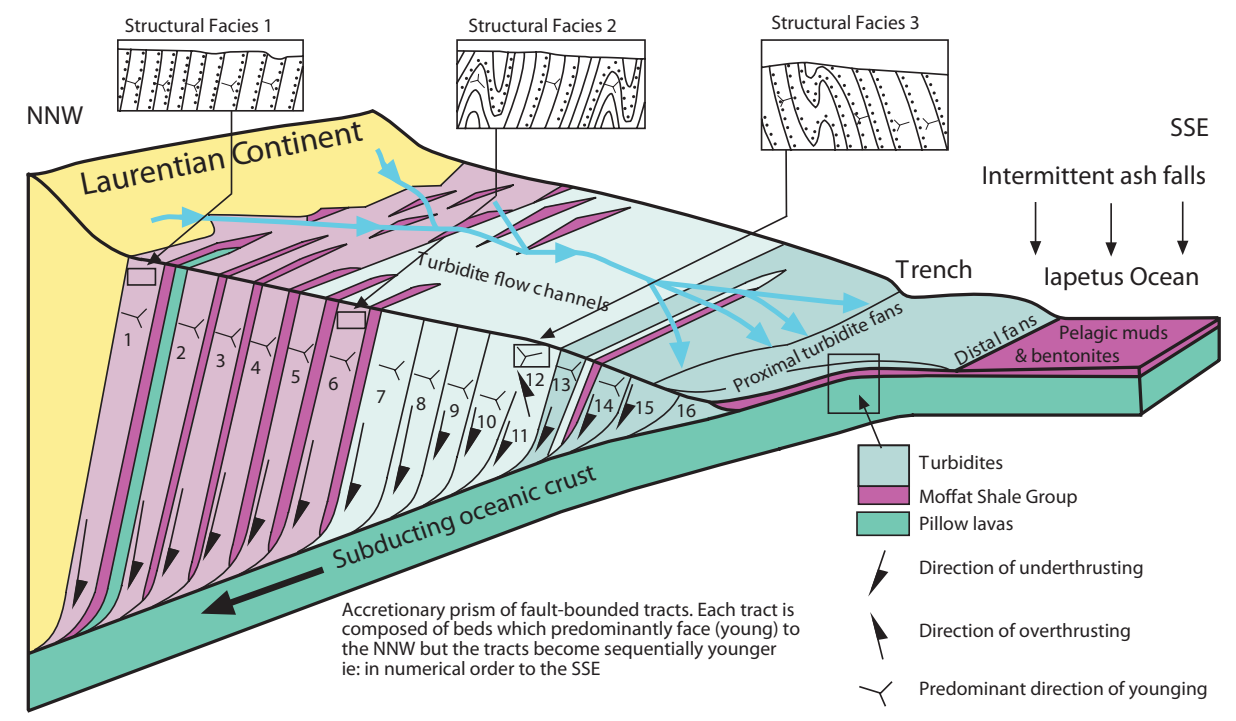

Figure 15 


\begin{tabular}{|c|c|}
\hline ey & \\
\hline 1 & High-pressure metamorphism \\
\hline & Arc volcanics / magma plumbing system \\
\hline 4 & Fore-arc basin sediments \\
\hline 5ब1 & Pillow basalt \\
\hline & Feeder dykes \\
\hline & Serpentinized sub-continental lithospheric mantle \\
\hline & Mantle \\
\hline & Accretionary complex ( $\sim \mathrm{HBC} / \mathrm{CBC})$ \\
\hline & Rift-related basic volcanisim \\
\hline & Dalradian Supergroup \\
\hline & Sub-Grampian Group Basement \\
\hline & Laurentian crystalline basement \\
\hline
\end{tabular}
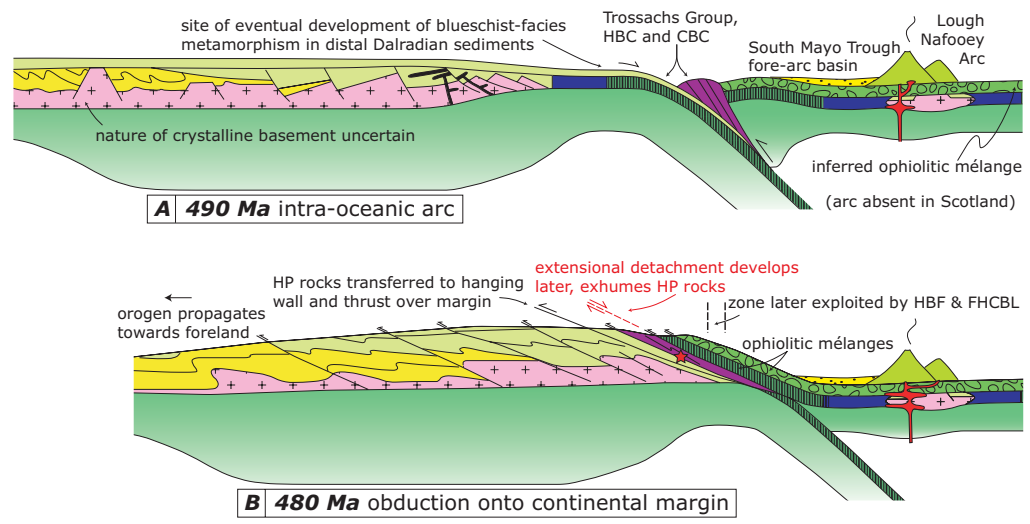

Figure 16 